NBER WORKING PAPER SERIES

\title{
CAPITAL FLOWS AND CONTROLS \\ IN BRAZIL: WHAT HAVE WE LEARNED?
}

\author{
Ilan Goldfajn \\ André Minella
}

Working Paper 11640

http://www.nber.org/papers/w11640

\author{
NATIONAL BUREAU OF ECONOMIC RESEARCH \\ 1050 Massachusetts Avenue \\ Cambridge, MA 02138 \\ September 2005
}

This paper is forthcoming in the NBER book "Capital Controls and Capital Flows in Emerging Economies: Policies, Practices and Consequences", organized by Sebastian Edwards. We thank Edmar Bacha, Sebastian Edwards, Tricia Kissinger and the participants in the International Capital Flows Conference and seminar at IEPE-CdG of Brazil for useful comments, Fernando Rocha and Fernando Lemos of the Balance of Payments Division of the Central Bank of Brazil (BCB) for valuable explanations of the Balance of Payments statistics, Jose Maria de Carvalho, Maria do Socorro Reboucas and Luciana de Oliveira of the Exchange and Foreign Capital Regulation Executive Office (Gence) of the BCB for precious and detailed comments on capital control issues. We are also grateful to Érica Diniz Oliveira and Eurípedes de Freitas Neto for excellent assistance with data. The views expressed here are those of the authors and not necessarily those of the Central Bank of Brazil. Goldfajn: Partner, Gavea Investimentos and Pontifical Catholic University of Rio de Janeiro (PUC-Rio). E-mails: igoldfajn@gaveainvest.com.br and goldfajn@econ.puc-rio.br. Minella: Research Department, Central Bank of Brazil. E-mail: andre.minella@bcb.gov.br The views expressed herein are those of the author(s) and do not necessarily reflect the views of the National Bureau of Economic Research.

(C)2005 by Ilan Goldfajn and André Minella. All rights reserved. Short sections of text, not to exceed two paragraphs, may be quoted without explicit permission provided that full credit, including $\odot$ notice, is given to the source. 
Capital Flows and Controls in Brazil: What Have We Learned?

Ilan Goldfajn and André Minella

NBER Working Paper No. 11640

September 2005

JEL No. F21, F32, F40

\section{$\underline{\text { ABSTRACT }}$}

This paper analyzes the relationship between capital account liberalization and macroeconomic volatility using Brazil as a case study. The paper provides several stylized facts regarding the evolution of capital flows and controls in Brazil in the last three decades. We conclude that, notwithstanding the financial crises and macroeconomic volatility of the recent past, capital account liberalization and the floating exchange regime have led to a more resilient economy. Further liberalization of the capital account is warranted and should be accompanied by a broad range of reforms to improve and foster stronger institutions.

\section{Ilan Goldfajn}

Gávea Investimentos

Rua Dias Ferreira, $1907^{\text {th }}$ andar

22431-050-Rio de Janeiro-RJ

BRAZIL

igoldfajn@gaveainvest.com.br

André Minella

Research Department

Central Bank of Brazil

SBS-Quadra 3-Bloco B-Edificio Sede- $9^{\text {th }}$ andar 70074-900-Brasília-DF

BRAZIL

andre.minella@bcb.gov.br 


\section{Introduction}

In the last few years, there has been a revival of the notion that capital controls may be a necessary evil. The main argument is that, although capital controls may introduce some economic distortions, excess capital mobility is partially responsible for financial crises (and macroeconomic instability) in emerging market economies (Stiglitz, 2002). Capital controls, goes the argument, provide emerging market economies the means to prevent these unpleasant consequences. However, recent papers (e.g., Edwards, 2005) have found no systematic evidence suggesting that countries with higher capital mobility tend to have a higher incidence of crises.

Detailed case studies may provide evidence for this debate. The Brazilian case provides an interesting example. Although Brazil still adopts a complex web of bureaucratic controls on capital flows, in the last fifteen years it has been more financially open than other large emerging market economies, in particular China and India. The analysis of Brazil, a large sub-investment grade emerging market economy, relatively integrated to the financial world and that has suffered both from financial crises and macroeconomic volatility, could shed further light on the capital controls issue. This paper details the experience of Brazil with capital mobility and controls.

Macroeconomic performance in Brazil has indeed been quite volatile over the last 30 years. Part of this volatility can be traced to a sequence of financial crises, sudden stops and a boom-and-bust pattern of current account deficits and capital flows. Brazil experienced two large cycles of current account deficits, one in the 1970s that lasted until the debt crisis of the early 1980s and the second in the 1990s, that ended with an abrupt reversal of the current account deficit after the 2002 electoral crisis.

Currently, Brazil is running a current account surplus of almost $2 \%$ of GDP, receiving approximately $2 \%$ of GDP in net foreign direct investment (FDI) and, for the first time in decades, reducing its external debt. In this environment, one wonders whether this performance is the sign of a new trend or the beginning of yet another cycle that eventually will reverse course. The issue is whether a regime based on a floating exchange rate, inflation targeting, fiscal responsibility and a relatively more open financial account induced a structural change? It is difficult to judge at this point. 
However, the combination of a few factors suggests a new trend. First, the floating exchange rate regime is providing more incentives for borrowers to better assess risk, in particular in the non-tradable sector. Second, exports are increasing in a magnitude not seen before, leading to a record low ratio (still high by international comparison) of external debt to exports. Third, the larger role of net direct investment in the latest surge in capital flows is encouraging from a debt accumulation perspective. Nevertheless, more analysis is needed. From an historical perspective, a relevant question is how does the current phase compare to the previous adjustment undertaken after the debt crisis of the 1980s? It is important to look at the past experience in Brazil.

In the last 15 years Brazil has also started liberalizing its capital account. The liberalization was a gradual process of establishing new rules on capital inflows and outflows. The result of the liberalization process was: (i) reduction or elimination of taxes on foreign capital financial transactions as well as of minimum maturity requirements on loans; (ii) elimination of quantitative restrictions on investments by nonresidents in financial and capital markets securities either issued domestically or abroad; (iii) permission for residents to issue securities abroad, including debt, without prior approval by the Central Bank; (iv) more freedom for residents to invest in FDI and portfolio abroad; and finally (v) introduction of currency convertibility initially through the mechanism of "international transfers in reais," whereby residents could transfer their resources abroad through the use of nonresident accounts. Since March 2005 a more direct procedure is in place.

In spite of the liberalization the resulting system does not mean unrestricted freedom or free convertibility. ${ }^{1}$ Export proceeds still are required to be converted into domestic currency ("exports surrender") and there are limits on foreign currency deposits. Current currency convertibility is based on monetary authority's rules instead of laws. Therefore, they can be lifted at any time. In addition, the public opinion still associates transfers abroad with illicit or antipatriotic practices. Also, notwithstanding the efforts to consolidate the exchange and capital account rules, the regulation is still fragmented and involves rules set in different contexts and driven by various motivations.

\footnotetext{
${ }^{1}$ The complete set of existing capital controls is presented in appendix A.
} 
A consolidation of the whole regulation in a unified law approved by Congress is necessary. Reduction in bureaucratic requirements is needed as well. The rules would become less uncertain and clearer. These changes would facilitate the change in mentality, originated back in the capital flight period, when transfers abroad were necessarily associated with illicit or antipatriotic practices.

The large volatility of capital flows has been one of the main arguments for those that oppose complete liberalization of capital movements. Since liberalization in Brazil has occurred in parallel to a period of higher macroeconomic volatility, one could wonder whether the case of Brazil reinforces the argument. The key points of the paper do not point in this direction:

i. The debt accumulation pattern changed substantially after the liberalization of the capital account and, especially, after the floating of the currency. The private sector decreased significantly its issuance of external debt. The reduction in private debt resulted partly from the abrupt interruption of access during the crises but also from the floating of the currency, which ended a period of implicit guarantees that included a fixed parity for borrowers;

ii. The profile of external financing has also changed since liberalization and the floating regime. After a period based on portfolio investment, FDI replaced it as the main financing source. Since 1998, net direct investment has comprised more than $100 \%$ of the net private capital flows. In general, FDI flows tend to be more stable and less correlated with the other flows. Long-term debt flows worked as a stabilizing factor during external crises, but behaved pro-cyclically during domestic crises;

iii. Net financial flows have, in general, financed current account deficits. Some differences emerge over time. Net financial flows financed: i) a strong accumulation of international reserves between 1992 and 1996; ii) a large expansion of the current account deficit from 1995-1997, representing a growth of both investment and consumption; and iii) an increase in the current account deficit from 1998-2001, resulting from a higher deficit in net income from abroad; 
iv. Following capital account liberalization, consumption-its growth rate and share in GDP — has been more stable than in the 1980s. In comparison to the 1990s growth episodes, economic growth in 2000-2001 and at the present (2004) took place in a different context. First, net capital flows have been of a lower magnitude and have been dominated by FDI. There has been no significant surge of short-term flows or portfolio investment. Second, the expansions have been accompanied by a more favorable situation in the trade balance. Third, one could argue that fundamentals improved with the change in the fiscal policy regime and the adoption of inflation targeting;

v. Sudden stops are more pronounced when the crisis is mostly domestically driven. Analysis using a vector autoregressive (VAR) estimation indicates that shocks to the country risk premium (measured by the EMBI) have the clearest effect on macroeconomic performance. Higher country risk levels induce greater interest rates, a more depreciated exchange rate, a reduction in capital inflows, and lower output. This lead us to the importance of building up good fundamentals in the economy.

These key points lead us to conclude that, notwithstanding the financial crises and macroeconomic volatility of the recent past, capital account liberalization has led to a more resilient economy. Therefore, further capital account liberalization should be considered. Liberalization should be accompanied by a broad range of reforms to improve and foster stronger institutions-such as approval of de jure central bank independence (not only de facto) — establish a longer track record of responsible fiscal policy (under the fiscal responsibility law) and reduce microeconomic inefficiencies and contractual uncertainties.

This paper is organized as follows. The next section provides the balance of payment stylized facts of the last three decades (current account cycles, capital flow cycles and composition, and debt accumulation). Section 3 describes the evolution of capital controls in Brazil and evaluates the benefits and costs of further capital account liberalization. Section 4 examines the volatility of capital flows in general and the behavior of the flows during financial crises. Section 5 analyzes the relationship between capital flows and macroeconomic performance in Brazil, evaluating what capital flows have financed, the recent growth pattern, and whether there is more 
consumption smoothing. In addition, we conduct some estimations on the determinants of capital flows and develop a structural VAR to estimate the relationship between capital flows and macroeconomic performance. The final section presents the main conclusions.

\section{Stylized facts}

Macroeconomic performance in Brazil has been volatile. Part of this volatility can be traced to the boom-and-bust pattern in the balance of payments. In fact, there have been long and pronounced cycles of current account deficits that ended abruptly. Each cycle had its own history: different types of capital flows financed the boom, sudden stops had different characteristics, and policy behavior was distinct.

Brazil is currently in a post-adjustment period, running both trade and current account surpluses. How does the current phase compare to the previous adjustment after the debt crisis?

This section provides the stylized facts of the main components of the balance of payments in the last decades, starting with the current account cycles, but then focusing on the capital flows, and the accumulation of external debt.

\subsection{Current account cycles}

In the last decades, Brazil experienced two large cycles of current account deficits, one in the 1970s, which lasted until the debt crisis of early eighties, and the second in the 1990s, punctuated by the crises of the last few years. Figure 1 shows the behavior of the current account and "private capital account", defined as the capital and financial accounts minus official-agency-related loans. ${ }^{2}$ These long periods of current account deficits were financed by voluntary capital flows. The first period was also a period of high average GDP growth, but this was not the case in the second period. Tables 1 and 2 show annual values and period averages for broad categories of the balance of payments as a percentage of GDP as well as for GDP growth rate.

\footnotetext{
${ }^{2}$ See Appendix $\mathrm{C}$ for a more detailed explanation of the capital flows variables used in the text. The figures in the text are shown either as percentage of GDP or based on constant 2003 U.S. dollars.
} 
The behavior of the current account has been, in general, dominated by the dynamics of the trade balance, whose deficit cycles are financed by large expansions of capital inflows. Figure 2 depicts the path of the trade balance and income balance (net remittances abroad of wages, profits, dividends, and interests), which are the main components of the current account. ${ }^{3}$

To analyze the current account performance in a broader macroeconomic context, internationally as well as domestically, including the effect of policy decisions, we subdivide the current account performance into five phases since the mid-1970s:

1974-1982: the second National Development Plan (II PND) and external debt accumulation. The economy presented large trade deficits from 1974 through 1980 averaging $1.6 \%$ of GDP — as a result of the heavy investments under the II PND and the two oil price shocks (1973 and 1979). The current account deficit was also exacerbated by the increase in U.S. interest rates in 1979. The deficits were financed basically by syndicated loans, in the context of a large expansion of international financial market liquidity. The external financing and investments under the II PND supported maintenance of high economic growth-GDP growth average of 7.0\% in the 19741980 period-despite the oil crisis. The inflation rate was also increasing, rising from $15.5 \%$ in 1973 to $110.2 \%$ in 1980 (measured by IGP-DI-General Price Index). However, external debt reached high unsustainable levels, leading to the 1982 external debt crisis;

1983-1994: External debt renegotiation, current account adjustment, and high inflation. With the interruption of voluntary capital flows, the economy had to generate trade surpluses to finance the income account deficits. In fact, after the 1981-1983 adjustment-maxi-devaluation of the domestic currency and tightness of macroeconomic policy - the economy generated large trade surpluses from 1983 through 1994 (averaging 4.0\% of GDP). In 1984, the trade surplus peaked at $6.9 \%$ of GDP. The current account balance stood around zero, except for the deficits at the end of 1986 and beginning of 1987, as a result of the Cruzado Plan. GDP growth fell

\footnotetext{
${ }^{3}$ Current account balance $\equiv$ trade balance + balance of services + income balance + current transfers balance.
} 
significantly, averaging 2.0\% from 1983 through 1992, reaching negative values in four of these years. It was also a period of high inflation, which peaked at $82.4 \%$ per month in March 1990 and 47.4\% in June 1994 (measured by IPCA-Broad National Consumer Price Index). Several stabilization programs tried to curb inflation, but achieved only temporary success. The end of the high inflation period came with the Real Plan, launched in July 1994. The process of external debt renegotiation underwent several phases, eventually concluding with the conversion of the loans into debt securities under the Brady Plan in April 1994. ${ }^{4}$ From 1992 through mid-1994, exchange rate policy, under a managed system, basically aimed to keep constant the purchasing power of the domestic currency, as we can see in Figure 3, which shows the real effective exchange rate and the trade balance;

1995-1998: New cycle of trade deficits, low inflation, and financial crises. The revival of capital flows to emerging market economies at the beginning of the 1990s, the regulation changes in the capital account, and the external debt restructuring ended the external financing restrictions of the 1980s. Moreover, for the first time in more than three decades, the economy enjoyed a low-inflation environment. In 1995, inflation fell to $22.4 \%$, and in 1998 reached $1.7 \%$. The stability brought by the Real Plan was also accompanied by a relatively short economic growth cycle, as depicted in Figure 4. In the initial months after the launch of the Real Plan, a floating system was adopted, followed the following year by a crawling band, which increasingly turned into a crawling peg. Figure 5 shows the steady and low rate of adjustment in the nominal exchange rate, which led to a substantial appreciation of the real effective rate (Figure 3). As a consequence of the surge in capital inflows, exchange rate overvaluation, and higher economic growth, large trade deficits emerged from 1995 through 1998 (average of $0.7 \%$ of GDP, which is a value largely underestimated by the increase in dollardenominated GDP resulting from the exchange rate overvaluation). The capital inflows that financed the deficits were predominantly portfolio investment (equity and debt securities), mainly until 1996-1997, when foreign direct investment started to assume greater significance. The economy was hit by external financial crises (Mexican, Asian

\footnotetext{
${ }^{4}$ In 1991, Brazilian government and the creditor private banks committee renegotiated the delayed interest payments of 1989 and 1990, and, in the following year, agreed on a term sheet that set some principles for the negotiation. At end-1993, a final agreement was reached, under the guidelines of the Brady Plan, by which the loans were converted into sovereign bonds, some of them having U.S. Treasury bonds as collateral. The conversion occurred in April 1994. For an institutional description of the process of renegotiation, see Cerqueira (2003).
} 
and Russian) and faced the domestic exchange crisis in 1998, which ended with the collapse of the exchange regime in January 1999;

1999-2001: Floating exchange system, inflation targeting, sound fiscal policy, and reversal of trade balance deficits. Economic policy had to deal with the exchange rate crisis and undertake a substantial change in the fiscal regime. A floating exchange rate system and an inflation-targeting regime were adopted, and substantial primary surpluses generated. Public sector primary surplus rose from 0.0\% of GDP in 1998 to $3.2 \%$ in the following year, reaching $4.4 \%$ in 2003 . The exchange rate depreciated from R \$/US\$ 1.22 in mid-January 1999 to R\$/US\$ 2.16 at the beginning of March. In June 1999, inflation targets were announced for that year and the following two years. It was a period of transition in terms of current account adjustment. The trade deficit fell from $0.8 \%$ of GDP in 1998 to $0.2 \%$ in 1999 , turning into a surplus of $0.5 \%$ in 2001 ;

2002-to the present: Confidence crisis and large current account adjustment. Throughout 2002, with the electoral uncertainties, the economy faced a confidence crisis. Country risk premiums and the exchange rate rose sharply. After the transition of the prior years, large trade surpluses solidified from 2002 onward. The surpluses are a consequence of significant exchange rate depreciation, strong world economic growth, and a few specific bilateral trade agreements. In 2003 and 2004, the trade surplus reached $5.0 \%$ and $5.6 \%$ of GDP (US\$ 24.8 billion and US\$ 33.7 billion), respectively, leading to a current account surplus of $0.8 \%$ and $1.9 \%$ of GDP. The positive results in the trade balance have been accompanied by both export and import growth. In 2004, exports and imports reached US\$ 96.5 billion and US\$ 62.8 billion, respectively, representing an increase of $32.0 \%$ and $30.0 \%$ in relation to the previous year. In fact, as we can see in Figure 6, the degree of trade openness of the economy-measured by the ratio of exports plus imports to GDP-has reached the record level of $26.5 \%$, in sharp contrast to a $14.0 \%$ average in the $1990 \mathrm{~s}$.

Therefore, Brazil is currently in a post-adjustment period, running both trade and current account surpluses. How does the current phase compare to the previous adjustment after the debt crisis? In both cases, there was a strong reversion of the trade deficit cycle. The trade balance rose from $-1.2 \%$ of GDP in 1980 to $6.9 \%$ in 1984, and from $-0.8 \%$ in 1998 to $5.6 \%$ in 2004 . Similarly, the trade adjustment was stimulated by 
a substantial exchange rate devaluation, which simultaneously generated significant inflationary pressures. However, the two adjustments present some important differences. First, the economic slowdown in the 1980s adjustment was substantially higher than in the 2000s. GDP accumulated a contraction of $6.3 \%$ in the 1981-1983 period. In the recent adjustment, the higher troughs, considering four-quarter cumulative GDP, were of $-0.5 \%$ in $1999: 3,0.0 \%$ in $2002: 2$, and $0.5 \%$ in 2003:4. Second, the exchange rate movement was higher in the recent adjustment. The real effective exchange rate rose by $35 \%$ in the months following the maxi-devaluation of February 1983 in comparison to the previous months. In 1999, the increase was around 47\%, and accumulated $66 \%$ until 2001. Third, the 1980s adjustment affected imports more intensely than exports. In 1984, imports fell by $39.4 \%$ relative to 1980 , while exports increased $34.1 \%$. The reduction in imports accounted for $56.8 \%$ of the change in the trade balance. In contrast, the recent adjustment has been incurred mainly by exports. In relation to 1998 , exports grew $42.9 \%$ and $88.6 \%$ in 2003 and 2004, respectively, and imports fell by $16.3 \%$ in 2003 and grew by $8.8 \%$ in the following year. As a consequence, although also reflecting changes in dollar-denominated GDP, the increase in the degree of openness has been substantially higher recently. Exports plus imports as a percentage of GDP rose from $18.1 \%$ to $21.6 \%$ between 1980 and 1984 , whereas it went from $13.8 \%$ in 1998 to $26.5 \%$ in 2004 . Fourth, in the 1980 s, the country was excluded from international capital flows, whereas, since the 1990s, it has been integrated in the financial markets. Fifth, the level of import tariffs is lower currently than in the 1980s. Sixth, macroeconomic regimes are completely different: low inflation, sound fiscal policy and better monetary institutions in the 2000s versus high inflation, unsound fiscal policy and weak monetary institutions in the 1980s.

Although the trade balance has played the main role in the current account boom-and-bust cycles, the income balance has undergone important changes as well. Since 1998, the income deficit has reached a higher level (1998-2003 annual average of $3.4 \%$ of GDP), as a result of the surge in capital inflows, which increased nonresidentowned assets in the economy. As a consequence of the external debt conversion under the Brady Plan and the change in the pattern of capital inflows-from loans to direct and portfolio investment-the composition of the income balance has changed significantly since the $1990 \mathrm{~s}$, as we can see in Figure 7. The deficit in portfolio investment income, rather than the deficit in other investments income, has become the 
main component since 1997, accounting for $46.8 \%$ of the investment income deficit from 2000 through 2003. The share of the income deficit attributable to direct investments rose to $22.6 \%$, whereas the share of the deficit attributable to other investments income decreased to $30.6 \%$.

\subsection{Capital flows cycles and their composition}

Although current account cycles have a corresponding capital flow financing, it is not necessarily the case that capital flows behave in the same manner in each cycle. In fact, there are major differences in the composition of capital flows across the current account cycles - private versus public, portfolio or FDI - that we opted to subdivide the capital flow behavior into three longer periods (instead of the five above). We detail the methodological decomposition of capital flows into six categories in Appendix C. Figures 8 and 9 show the path of the main categories.

1970s-1982: Loan flows and external debt accumulation. In the context of a significant liquidity expansion in international financial markets, Brazil received massive capital inflows. Table 3 shows, for each period, the average of different flows (as a percent of GDP). The private capital account balance averaged 3.8\% of GDP from 1974 through 1982. As recorded in Figure 9, the majority of capital inflows were loans, comprising $74.3 \%$ of the private capital balance. In contrast, portfolio investment was minimal (a 5.4\% share in the flows). As a result, gross external debt, as a percentage of GDP, from $16.8 \%$ in 1970, reached $31.5 \%$ in 1982, and peaked at 53.8\% in 1984 (new flows in the context of debt renegotiation, and maxi-devaluation of domestic currency reducing dollar-denominated GDP);

1983-1991: Shortage of capital flows. The external debt crisis and debt renegotiation-extended until 1994-dominated the period. The scarce capital flows were basically part of debt renegotiation. The private account balance averaged $1.7 \%$ of GDP in the period (declining to 1.0\% when excluding 1983-1984). In 1983 and 1984, the country still received positive loan flows, but under the debt renegotiation. In fact, the loan flows balance remained negative for one decade (1985-1994). Likewise, the negligible positive portfolio investment turned into (negligible) negative flows. Net 
direct investment was affected as well. As a percentage of GDP, they fell from $0.6 \%$ of GDP, in the previous period, to $0.2 \%$;

1992-to the present: Financial openness, reintegration in the international financial markets, and large swings of capital flows. The country was reintegrated into cross-border flows. The resumption of capital flows to Brazil was associated with several factors: i) increase in international liquidity and expansion of pension and hedge funds; ii) the process of capital account liberalization; iii) high yield differentials between domestic and foreign bonds; iv) the end of the external debt restructuring period; and v) higher macroeconomic stability with the launch of the Real Plan. The three main characteristics of capital flows in this period were the following: i) important role played by portfolio investment; ii) large swings in capital flows ("sudden stop crises"); and iii) increasing role of foreign direct investment.

The resumption of capital flows was dominated by portfolio investment. ${ }^{5}$ Except for brief pauses during the Mexican and Asian crises, portfolio inflows increased systematically and reached a four-quarter cumulative average of US\$ 20 billion between 1996 and mid-1998. Portfolio investment accounted for $73.0 \%$ of the private capital account balance between 1992 and 1998, averaging 2.3\% of GDP. In general, debt securities flows were larger than equity flows. The expansion of debt securities was reinforced by the return of the government to the international financial markets after the debt restructuring, with the first issuance of sovereign bonds taking place in mid1995.

Portfolio investment also played an important role in the large capital flow swings associated with the financial crises, more intensely in the domestic crises (exchange crisis in 1998-1999 and confidence crisis in 2002). The net portfolio balance amounted to US\$ -11.2 billion from 1998:3 through 1999:1, and to US\$ -7.6 billion in the last three quarters of 2002.

\footnotetext{
${ }^{5}$ The category portfolio investment follows IMF's definition. It is represented by cross-border investment in equity securities that is not classified as direct investment, and debt securities. This category includes securities negotiated in Brazil and abroad
} 
The other component that played a key role during the sudden stop crises was "other short-term assets". These flows are, in general, negative because they basically refer to transfers of domestic currency abroad. Similar to portfolio investment, the main negative peaks of this group were associated with the financial crises. The higher trough took place in the exchange crisis, when its negative balance summed to US\$ -15.2 billion in the last three quarters of 1998. These outflows were associated with growing doubts about the sustainability of the exchange rate regime, and the corresponding expectations of currency devaluation. It was a way of protecting asset values in terms of foreign currency and having capital gains in terms of domestic currency. For those who had issued foreign-currency denominated or linked debt, it represented a way of hedging against prospective devaluation. After the devaluation in January 1999, these outflows fell significantly and were increasingly lower, except during the confidence crisis, when they reached a balance of US\$ -5.6 billion in the last three quarters of 2002.

The main change in the profile of capital flows in the second half of the 1990s was the increasing role played by foreign direct investment. In fact, since 1998, net direct investment has become the main inflow group. These inflows followed a cycle of expansion, from mid-1990s through 2002, peaking in 1999 and 2000. The expansion was stimulated by the improvement in domestic macroeconomic conditions with the Real Plan, the lifting of restrictions on foreign investments in some sectors, and the wave of privatizations. The change to a low-inflation environment has reduced the level of uncertainty in the economy and ended the distortions brought about by high inflation. Furthermore, the passage to a more solid macroeconomic regime in 1999 has built a better economic environment.

Privatization was not, however, the main component of net foreign direct investment (Figure 10). From 1997 through 2000, privatizations accounted for $25.0 \%$ of net FDI. These data, however, tend to underestimate the contribution of privatization because they do not include additional capital inflows in the form of investment following privatization. In spite of the reduction in FDI, the levels have been relatively high. Net FDI stood at US\$ 10.1 billion and US\$ 18.2 billion in 2003 and 2004, representing $2.1 \%$ and $3.0 \%$ of GDP, respectively. ${ }^{6}$ Therefore, in recent years, the

\footnotetext{
${ }^{6}$ The 2004 figures include large operations involving a single firm.
} 
pattern of external financing has shifted from debt inflows to direct investment. Moreover, as we can see in Figure 8, net direct investment was much less affected than the other components during the crises.

Flows related to official agencies have demonstrated large increases when there was a sharp reduction in private capital flows, working clearly as "compensatory flows". Figure 11 shows the balance of the private capital account and the officialagency-related loans. The role of these flows is evident during both domestic crises. Between 2002:2 and 2003:3, net credits from the IMF reached US\$ 22.7 billion (a gross credit of US\$ 33.6 billion). The correlation coefficient between the two groups is -0.17 (1992:2-2004:2).

Using the definition of short- and long-term flows described in Appendix C, Figure 12 shows that short-term debt flows were preponderant between 1993 and 1996, and were clearly affected by the crises. Long-term debt flows, in turn, fell significantly during the domestic crises. Therefore, it seems that short-term flows were more sensitive to contagion crises than long-term flows, but the latter did not work as a factor of stability during domestic crises.

\subsection{The stocks: has the accumulation of external debt been halted?}

The revival of capital flows to Brazil was accompanied by an increase in external debt, mainly in the second half of the 1990s. Figure 13 shows gross and net external debt as a proportion of GDP. ${ }^{7}$ This ratio, however, is largely affected by the effect of exchange rate variations on GDP measured in dollars. Considering the debt level at constant prices, Figure 14 shows the path of both public and private external debt.

The debt accumulation in the second half of the 1990s was primarily undertaken by the private sector. The lower interest rates on external debt relative to domestic debt, the stability of the exchange rate, and the associated implicit guarantee of exchange rate system continuity worked as important stimuli for the issuance of external debt, in the

\footnotetext{
${ }^{7}$ Net external debt is obtained subtracting reserves, commercial banks' assets, and Brazilian credits abroad from gross debt.
} 
context of abundant international liquidity. Private external debt was rapidly increasing between 1992 and 1998, rising from US\$ 21.9 billion to US\$ 112.3 billion. As a consequence, the share of private sector debt in total external debt rose from $17.0 \%$ to $50.2 \%$.

The debt accumulation pattern has changed substantially after the float and large depreciation of the currency. The private sector significantly decreased its issuance of external debt, leading to a strong decline in private external debt, from US\$ 111.6 billion in 2000 to US\$ 71.7 billion in September 2004. The reduction in private debt resulted partly from the abrupt termination of access during the crises, but also from the increased uncertainty that a floating exchange regime introduces to borrowers. For agents that do not have dollar revenues, it is highly risky to issue foreign currency debt. Thus, the trend is for firms in the non-tradable sector to repay their debts.

The public sector has also changed its behavior after the float of the currency. Brazil returned to issue sovereign bonds in 1995, but, since 1998, issuance of public external debt has been dominated by compensatory flows. After a downward trend until 1997, the growth of public sector debt resumed during the crises under IMF programs. IMF debt rose from nearly zero in 1997 to US\$ 8.8 billion in 1999, falling back in the following year with the repayments. However, in the subsequent programs, debt owed to the IMF debt resumed an upward trend, peaking at US\$ 33.5 billion in the third quarter of 2003. Between end-2000 and the third quarter of 2003, IMF accounted for $90.1 \%$ of the US\$ 35.2 billion increase in public external debt. The latest repayments to the IMF in 2004 have reduced total public sector debt by US\$ 9.3 billion between the third quarters of 2003 and 2004. Overall, private debt was partly replaced by public debt.

In the aggregate, however, the total external debt level has been decreasing since 2000. After peaking around US\$ 225 billion in 1998-1999, it reached US\$ 202.2 billion in September 2004. As a proportion of GDP, after reaching $45.9 \%$ of GDP in 2002, total external debt decreased to $34.9 \%$ in September 2004. The net-external-debt-ratio-toGDP fell from $35.9 \%$ to $24.9 \%$ in the same period. 
With the large expansion in exports in recent years, the ratio of gross external debt to 12-month-exports has declined substantially, as we can see in Figure 15, reaching 2.2 in September 2004, the lowest value in the last thirty years, and 1.6 when considering net debt. Likewise, the proportion of interest payments to exports has declined steadily. It reached $15.9 \%$ in September 2004, which also represents one of the lowest values in the last three decades, as recorded in Figure 16.

One wonders whether the remarkable decrease in debt since 2000 is the sign of a new trend or the beginning of yet another cycle that eventually will reverse its course. It is difficult to judge at this point. However, the combination of a few factors suggests a new trend. First, more incentives are being provided by the floating regime for borrowers to better assess risk, in particular in the nontradable sector. Second, exports are increasing in a magnitude not seen before, leading to a record low ratio (although still high by international comparison) of external debt to exports. Third, the larger role provided by net direct investment in the latest surge in capital flows is encouraging from a debt accumulation perspective.

\section{Capital controls}

During the 1990s, Brazil liberalized its capital account, in parallel to the process of trade liberalization and the surge in capital inflows. The capital account liberalization was a gradual process of establishing new rules on capital inflows and outflows. Figure 17 shows an index of capital control estimated for 1990-2004: the lower the index the more liberalized is the capital account. ${ }^{8}$ The list of liberalization measures is vast, mostly adopted in the first half of the decade. Appendix A shows the current major restrictions, and Appendix B presents a chronology of the main changes in capital account regulation in the 1990-2004 period.

The result of the liberalization process was the following: (i) reduction or elimination of taxes on foreign capital financial transactions as well as of minimum maturity requirements on loans; (ii) elimination of quantitative restrictions on investments by nonresidents in financial and capital markets securities issued

\footnotetext{
${ }^{8}$ The index was elaborated using the chronology in Appendix B. We have normalized December 1999 equal to 100 , and assigned -1 to each liberalizing measure and +1 to each restrictive one.
} 
domestically or abroad; (iii) permission for residents to issue securities abroad, including debt, without prior approval by the Central Bank; (iv) more freedom for residents to invest in FDI and portfolio abroad; and finally (v) introduction of currency convertibility through the mechanism of "international transfers in reais," whereby residents could transfer their resources abroad through the use of nonresident accounts. Since March 2005, a more direct procedure is in place.

This liberalization process occurred, however, without the necessary changes in the overall legislation. Each new liberalizing rule was inserted at the margin of the existing legislative framework resulting in a complex web of regulations. The present set of regulations comprises different types of rules (laws, decree-laws, resolutions, memos, etc.) established in different contexts and driven by diverse motivations.

The existing legislative framework dates back as early as the 1930s. It was originally based on less liberal principles and was implemented before financial integration was an important consideration. The most important pillar of the existing legislation is that the domestic currency is the only legal tender; i.e., payments in foreign currency are not allowed. ${ }^{9}$ Moreover, banking deposits in foreign currency are usually not allowed. ${ }^{10}$ The second pillar is that export proceeds are required to be converted into domestic currency ("exports surrender"). ${ }^{11}$ Furthermore, the netting of payments is not allowed, e.g., exporters cannot use their proceeds to pay for an import or an external debt before converting them into domestic currency. ${ }^{12}$

However, the most important pieces of capital flow legislation were introduced in the $1960 \mathrm{~s}^{13}$ to regulate foreign direct investment and loans. According to that regulation, foreign capital inflows should be registered (and income tax paid) in order to obtain permission for associated outflows (profits, interests, royalties, and repatriation).

\footnotetext{
9 Decree 23,501, 11.27.33, replaced by Decree-Law 857, 9.11 .69 (the exception was given for some cases, such as contracts related to imports and exports, exchange contracts, and debt involving nonresidents as creditor or debtor). Law 10,192, 2.14.01 (previously Provisory Measure 1,053, 6.30.95), reaffirmed those restrictions, making also clear the restriction involves indexation to a foreign currency.

${ }^{10}$ There are few exceptions. Currently, foreign currency deposits are allowed for embassies, international organisms, oil and electric energy companies, insurance companies, institutions operating in the floating exchange market, foreigners temporarily in Brazil, Brazilians living abroad, Brazilian Postal Service Company (ECT), and foreign cargo companies.

${ }^{11}$ Decree 23,258, 10.19.33.

12 Decree-Law 9,025, 2.27.46.

${ }^{13}$ Laws 4,131 (9.3.62) and 4,390 (8.29.64), and Decree 55,762 (2.17.65).
} 
This basic legislation has remained in place without major changes. ${ }^{14}$ The legislation also sets the grounds for the existence of two separate exchange markets.

The 1960s legislation was enacted in the context of the Bretton Woods system when private capital flows were scarce and dominated by direct investment. Domestically, financial markets were underdeveloped, currency was weak-reflecting the effects of inflation-and import substitution policies at their peak. The basic idea was to control and limit currency convertibility. Access to foreign currency should be restricted to imports—-heavily taxed-and remittances, within certain limits, should be associated with previous registered inflows. This legislation survived the next couple of decades when the scenario was dominated by the debt crisis and unstable macroeconomy.

Nevertheless, the strong capital controls system did not prevent capital flight. The "parallel" (or black) exchange market gained importance. The exchange rate spread over the official exchange rate averaged $40 \%$ over the 1980 s, peaking at $170 \%$ in May 1989. ${ }^{15}$ The high spread of the exchange rate over the official market encouraged import overinvoicing and export underinvoicing. Even individuals that traveled abroad had to resort to the (illegal) parallel market because of the extremely low limits of foreign currency that they were allowed to buy in the official market.

The first change in the regulation occurred in 1987 when portfolio inflows were allowed through the establishment of foreign capital investment companies, foreign capital investment funds, and stock and bond portfolios (the so-called Annexes I to III).

Other changes followed. An important reference point was the liberalization of the securities market to foreign institutional investors in 1991, with the so-called Annex IV. Other important measures that stimulated foreign capital flows at the beginning of the 1990s were the following: i) reduction in the tax on remittances abroad of profits and dividends; ii) authorization for conversion of external debt instruments of the federal public sector, bonds, and deposits denominated in foreign currency for use in the National Privatization Program; iii) authorization for foreign investors represented by

\footnotetext{
14 The main changes were the end of restrictions on investments in some sectors and lower tax burden.

${ }^{15}$ Ipeadata.
} 
funds, investment companies, and institutional investors to operate in the options and futures markets for securities, exchange, and interest rates; and iv) authorization for the issuance abroad of convertible debentures and of Depository Receipts representing Brazilian securities, such as the American Depositary Receipts (ADRs).

The creation of the "floating exchange rate market"—also called "dollar-tourism market"—at end-1988, alongside the "commercial or free exchange rate market", was another important reference point in the process of capital account liberalization. The goal was to bring exchange operations that were conducted in the "parallel market" into a regulated market. ${ }^{16}$ Increasingly, the regulation broadened the operations that could go through the new market. As a consequence, the parallel market lost its economic significance, as reflected in the spread, which decreased significantly, averaging $14 \%$ and $4 \%$ in the first and second halves of the 1990s. The rates in the floating and free exchange markets were aligned in 1996, and the markets in practice unified in $1999 .{ }^{17}$

The floating exchange rate market allowed further liberalization of residents outflows. The main change was to broaden the possibility of conversion of domestic into foreign currency through the nonresident accounts (the so-called CC5 accounts), starting at the end of 1988 and further developed in the following decade. ${ }^{18}$ The $1960 \mathrm{~s}$ legislation determines that nonresidents could transfer abroad, regardless of any authorization, the balance not withdrawn coming from foreign exchange sales or money orders in foreign currency. However, it did not establish what would happen to resources from other sources. At the end of the 1980s and beginning of the 1990s, the central bank extended the possibility of transferring abroad, giving a "general and public authorization" for transfers from nonresident financial institutions, as pointed out in Banco Central do Brasil (1993), an important official text that clarified the changes in the exchange regime. Any transfers above US\$ 10,000.00 (afterwards changed to R\$ 10,000.00), however, should be identified and registered in the Central Bank Information System (Sisbacen).

\footnotetext{
${ }^{16}$ Banco Central do Brasil (1993).

${ }^{17}$ Resolution 2,588, 1.25.99.

${ }^{18}$ See section "Resident and nonresident accounts" in Appendix B for the specific regulation.
} 
This transfer mechanism through the nonresident account was named "international transfers in reais" (TIR). In practice, residents in Brazil could deposit in a nonresident bank's account held in a domestic bank, that could convert domestic into foreign currency. In other words, residents could transfer money abroad making these deposits and asking the nonresident financial institution to buy foreign currency to make the deposit in an account abroad. ${ }^{19}$ This mechanism has represented a crucial change in the capital account regulation: from a system based on strict limits to currency conversion-restricted only to nonresidents and outflows related to previous inflowsto a much broader scope, extended in practice also to residents. As stressed in Franco and Pinho-Neto (2004), this rule represented the introduction of de facto convertibility.

Convertibility was enhanced by the authorization for non-financial resident firms to invest abroad up to US\$ 1 million each twelve months-later expanded to US\$ 5 million-without prior authorization. When above this limit, investors should provide information to the Central Bank 30 days ahead of the exchange transaction. ${ }^{20}$ These investments were conducted in the floating exchange rate market. ${ }^{21}$

From 1993 to 1996, however, capital inflows reached levels that prompted the monetary authorities to adopt restrictive measures, ${ }^{22}$ some of them temporarily relaxed after the Mexican crisis. The vast liquidity in international markets, the more open capital account and the interest differential between domestic and foreign interest rates ${ }^{23}$ led to a surge of capital inflows that pressured the exchange rate and the money market. In fact, the restrictive measures were motivated by concerns regarding the amount of sterilization operations-with their fiscal cost associated with the yield differentialsand the short-term tenor of a significant portion of the inflows.

The restrictive measures involved quantitative and price-based measures, which constantly evolved as market participants found ways to circumvent them, as shown in

\footnotetext{
${ }^{19}$ For a more recent explanation of the international transfers in reais, see Schwartsman (2004).

${ }^{20}$ See section "Brazilian capital abroad" in Appendix B for more details.

${ }^{21}$ From 1988 through 1992, Brazilian investment abroad was required to be compensated by a sale to the Central Bank of gold bought in the domestic market for a value equivalent to the investment.

${ }^{22}$ See Ariyoshi et al. (2000), Cardoso and Goldfajn (1998), Garcia and Barcinski (1998), and Garcia and Valpassos (1998).

${ }^{23}$ Cardoso and Goldfajn (1998) and Garcia and Barcinski (1998) have shown that capital flows to Brazil responded to interest rate differentials. Our estimations also provide evidence that domestic interest rates have stimulated capital flows.
} 
Garcia and Valpassos (1998) and Carvalho (2005). ${ }^{24}$ The regulatory changes discouraging capital inflows included: i) increase in the financial transaction tax on capital inflows, in particular for shorter term flows; ii) increases in the minimum maturity requirements for capital inflows; and iii) further quantitative restrictions on several portfolio investment instruments. For example, foreign investment under Annexes I to IV was prohibited to channel resources to fixed-yield bonds and debentures (although partially compensated by the creation of specific foreign capital fixed-income funds-FRF-CE). These prohibitions were gradually expanded over the period 1993-1995, with successive measures restricting investment in derivatives markets - unless as an explicit hedge of existing contracts-certificates of privatization and related securities, Financial Investment Funds (FAF), futures and options markets, and finally other specific debt securities.

Measures aimed to stimulate outflows, such as the permission for prepayment of foreign borrowing and import financing, were also adopted. New channels for Brazilian investment abroad were established, such as the Brazilian Depositary Receipts (BDRs) regulation, which allows residents to purchase securities of nonresident companies in Brazil, or the creation of Foreign Investment Funds, which facilitates purchases of debt securities by residents in international markets.

The measures easing outflows make it clear that the overall objective was to reduce net inflows without affecting the trend towards greater integration with international financial markets. In fact, the restrictive measures did not reverse the liberalization trend, but represented a "cycle" of restrictions around that trend, as we can see in Figure 17. Furthermore, Figure 18 decomposes the index into controls on outflows and inflows, showing that the focus of the measures was inflows.

The restrictive capital inflow measures did not involve foreign direct investment. On the contrary, the liberalization trend continued through the mid-1990s. The constitutional distinction between Brazilian firms-licensed under Brazilian laws and with headquarters and administration in the country—and Brazilian firms of national capital—restricted to those under control of residents—were removed. Likewise, new

\footnotetext{
${ }^{24}$ Carvalho (2005) presents different strategies used by market agents to circumvent the regulation.
} 
opportunities for investment in public utilities were opened with the Concession Law, as well as with the increase in the ceiling for nonresidents' ownership of financial institutions. Moreover, the income tax on remittance of profits and dividends abroad was removed.

The motivation for the restrictions adopted in this period stands in sharp contrast to that of the 1960s legislation. The latter was established in the context of a scarcity of foreign resources in order to prevent capital outflows - the so-called capital flight. The objective was to restrict currency convertibility to avoid pressures on the exchange rate-and their consequences on inflation and import costs-and try to preserve the demand for domestic currency. In contrast, the 1993-1996 restrictions were aimed to reduce capital inflows and ease outflows. In fact, as shown in Cardoso and Goldfajn (1998), capital controls were endogenous. The government reacted strongly to capital flows by increasing controls on inflows when these were booming and relaxing them in moments of distress. However, Cardoso and Goldfajn (1998) also show that, although the volume and composition of capital flows responded to the restrictive measures, these measures were ineffective in the long run.

Starting in 1997, capital controls on inflows were again relaxed with the outbreak of the Asian and Russian crises, and later on with the Brazilian exchange crisis. The measures from 1997 through 1999 included reduction and later elimination of both the minimum average maturity for external loans and the financial transaction tax on capital inflows, ${ }^{25}$ and elimination of the restrictions on investments under Annexes I to IV. In 1999, the 1993-1996 restrictive measures had all been lifted. The greater capital account openness culminated in Brazil accepting the obligations of IMF Article of Agreement VIII in November 1999. ${ }^{26}$

In the first half of the 2000s, under the new floating exchange regime adopted in 1999, nonresidents were finally allowed to invest in the same instruments in the

\footnotetext{
${ }^{25}$ A 5\% tax is applied to inflows related to external loans with a minimum coverage maturity of up to 90 days.

${ }^{26}$ This article precludes the country members, without the approval of the Fund, from imposing restrictions on the making of payments and transfers for current international transactions. It also forbids discriminatory currency arrangements or multiple currency practices. Previously, Brazil availed itself of the transitional arrangements of Article XIV, which allows exchange restrictions but requires countries to take measures towards acceptance of Article VIII as soon as conditions permit.
} 
financial and capital markets that residents do. In addition, the prepayment of external debt was allowed as well as the conditions for the issuance of real-denominated external debt were set. Also, an important development of that period was to eliminate the prior approval of external loans by the Central Bank of Brazil. In effect, the current registration process for capital flows has become a documentary requirement instead of part of an active authorization process.

More recently, at the beginning of March 2005, the Central Bank announced the unification of the exchange markets and clearer rules concerning conversion of domestic currency into foreign currency. For example, the international transfer mechanism through deposits in accounts of nonresident financial institutions was replaced by a more direct procedure.

In spite of the large liberalization of the 1990s, Arida, Bacha, and Lara-Resende (2004) point out that the resulting system does not mean unrestricted or free convertibility. The authors list several limits of the current system, including that current convertibility is based on monetary authority's rules instead of laws. Therefore, they can be lifted at any time. In addition, the public opinion still associates transfers abroad with illicit or antipatriotic practices. ${ }^{27}$

In fact, notwithstanding some efforts to consolidate the exchange and capital account rules, the regulation is still fragmented and involves rules set in different contexts and driven by various motivations. A consolidation of the whole regulation in a unified law is necessary. Reduction in bureaucratic requirements is needed as well. The rules would become less uncertain and clearer. These changes would facilitate the change in mentality, originated back in the capital flight period, when transfers abroad were necessarily associated with illicit or antipatriotic practices.

A further step could be adopted. Arida (2003a, 2003b, 2004) defends a change in legislation so as to assure unrestricted convertibility. He argues that the introduction by law of free convertibility-defined as the absence of any restriction to the exchange between foreign and domestic currencies, although keeping the domestic currency as the

\footnotetext{
${ }^{27}$ See Gleizer (2005) for a collection of papers on exchange arrangements and capital flow regulation in Brazil.
} 
only means of domestic payments-would give a positive signal. Arida (2003b, 2004) stresses that free convertibility should not be adopted immediately, but announced previously and implemented gradually, accompanying also some macroeconomic indicators and institutional changes, such as central bank independence. ${ }^{28}$

Our view is that much can and should be done in order to simplify and consolidate current exchange regulations. The system is excessively bureaucratic and complicated, consequence of the patch pattern way it was created as the macroeconomic conditions evolved and ideology changed. At this juncture a consolidation of the advances of the last decade should be unified in a consolidated and simple law. Further liberalization steps, beyond consolidation, will need to be accompanied by additional institutional developments as establishing central bank autonomy, solidifying the fiscal responsibility law and the need for a mature fiscal policy, reaching a stronger consensus about the necessity of lower inflation, and implementing judiciary reform and further microeconomic reforms. Complete freedom of capital flows should emerge as a "natural" consequence of improvements and maturity in institutions.

In summary, regarding capital controls in Brazil: i) liberalization has advanced significantly since the 1990s; ii) the restrictive measures of the 1993-1996 period were mostly aimed at reducing large capital inflows and did not reverse the liberalization trend; iii) currency convertibility has increased significantly; iv) the current situation calls for a simplification of the exchange market and elimination of existing bureaucracy; and v) the advances achieved in the last decade (through several rules) should be consolidated in a simple law approved by Congress.

\section{Volatility of capital flows and financial crises}

The large volatility of capital flows has been one of the main arguments for those that oppose complete liberalization of capital movements. Is the volatility of capital flows in Brazil a permanent feature? Is the volatility large across the different types of flows?

\footnotetext{
${ }^{28}$ Arida's proposal has generated some controversy. An opposite view can be found in Ferrari Filho et al. (2005).
} 
Besides the normal volatility analysis, it is important to verify the behavior of capital flows in periods of stress, such as in financial crises. This provides more qualitative information regarding the whole distribution of the flows. The Brazilian economy was affected by four external and two domestic crises in the last decade: i) Mexican (late 1994); ii) Asian (last quarter of 1997); iii) Russian (third quarter of 1998); iv) Brazilian exchange crisis (late 1998-early 1999); v) Argentinean (second half of 2001); and vi) Brazilian confidence crisis (last three quarters of 2002). Figure 19 depicts monthly averages of the EMBI+ Brazil, ${ }^{29}$ whose peaks reflect the crises. In this section we conduct some basic estimates of volatility of capital flows and assess their behavior during the crises.

\section{Volatility of capital flows}

The results on volatility are shown in Table 4 for the 1992:1-2004:2 period (quarterly data). Considering the coefficient of variation (ratio of standard deviation to average), net direct investment is the less volatile group, in line with the results in Prasad et. al. (2003), which shows, using a dataset of 76 industrial and developing countries, that bank borrowing and portfolio flows are substantially more volatile than FDI. Portfolio investment is the most volatile group. The standard deviation and coefficient of variation of portfolio investment are 1.3 and 2.0 higher than those for direct investment. Note that loans are extremely volatile as well. Thus, according to these indicators, financing through debt securities is not more volatile than via loans. Furthermore, the variance of direct investment is actually underestimated because its average in the second half of the sample is substantially higher than in the first half. Considering the 1997:1-2004:2 sample, its variation coefficient decreases to 0.5, whereas that of portfolio investment rises to 3.0.

When we use net flows, however, the variation coefficient is sensitive to averages close to zero. To minimize this problem, we estimate separately the volatility for inflows and outflows, which are shown in Table 5. Similar to net flows, inflows and outflows of portfolio investment present a standard deviation significantly higher than

\footnotetext{
${ }^{29}$ The series refers to the sovereign spread of the EMBI until 1997:12, and of the EMBI+ thereafter. For simplicity, we call it EMBI along the text.
} 
that for FDI. ${ }^{30}$ Likewise, contrary to expectations, the item "other long-term loans", when compared to the group portfolio investment, does not present a higher volatility. ${ }^{31}$ Note also that trade credits present a high variation coefficient.

The literature has emphasized the volatility of short-term flows and their role during the financial crises. The figures on the greater stability of FDI flows support this analysis. However, the same does not apply when we compare short- versus long-term debt flows. Long-term debt flows present a higher standard deviation and coefficient of variation. On the other hand, when including the groups "other short-term assets" and net direct investment in the short- and long-term flows, respectively, the volatility is significantly lower in the latter. Nevertheless, as we can see in Figure 12, net short-term debt flows have been relatively more stable since mid-1999, when compared to the previous period.

We also conduct some basic analysis of the correlation between selected groups (Table 6). The groups equities, debt securities, loans and trade credits are positively correlated, although the correlation coefficients are not large. ${ }^{32}$ Net direct investment, in turn, usually presents negative correlation with those groups. The correlation between short- and long-term flows (not shown) is significantly higher, mainly when we use annual data (correlation coefficient of 0.73). This result strengthens the previous findings concerning similar volatilities of short- and long-term debt flows.

\section{Capital flows during crises}

Sudden stops were more intense during the domestic crises than during the external ones. Table 7 shows net flows previous to and during the crises. In the domestic crises, the expectation of a change in regime and depreciation of domestic currency stimulated capital outflows and discouraged capital inflows significantly. Net flows during the Mexican and Asian crises were negative only for one or two quarters,

\footnotetext{
${ }^{30}$ Although the variation of coefficient of inflows and outflows of portfolio investments is lower than that of FDI, when we consider the 1997:1-2004:2 period, the result is reversed. Furthermore, under the point of view of pressures on the balance of payments, the standard deviation measure seems to be more relevant because it captures the absolute amount of change in the flows.

${ }^{31}$ It presents a higher variation coefficient when considering inflows and similar in the case of outflows, although it has, at the same time, a lower standard deviation.

${ }^{32}$ Bosworth and Collins (1999) have found no or very low correlation between foreign direct investment, portfolio investment and loans for a 58-developing-country sample.
} 
and recovered quickly_four-quarter cumulative flows remained positive. In contrast, during the exchange crisis (1999)—considering also the Russian crisis period-and the confidence crisis (2002), the reversal of flows was large and lasted at least three quarters. From 1998:3 through 1999:1, the cumulative private capital account balance stood at US\$ -23.2 billion, after having accumulated US\$ 48.1 billion in the previous four quarters. In the second half of 2002, flows reached US\$ -12.7 billion, following US\$ 13.1 billion accumulated in the previous four quarters.

The reversal in capital flows in the exchange crisis was higher than in the confidence crisis for the following reasons: i) the economy was receiving large inflows, in part because of the huge spread between domestic and foreign interest rates; ii) in mid-1998, despite FDI growth, most of the flows consisted of portfolio investment, loans and trade credits, which tend to respond more quickly and intensely to crises. In contrast, FDI comprised a large part of the flows when the confidence crisis took place; iii) after some point in time most agents considered the collapse of the exchange regime unavoidable, with the corresponding strong devaluation of domestic currency, remaining doubts mainly about when it would take place. In this context, protection of asset values meant large positive net capital outflows. In contrast, the confidence crisis occurred in a different regime, and was reversed as the elected government displayed some strong signs of continuity in macroeconomic policy; and iv) the exchange depreciation during the confidence crisis, after some point in time, tended to discourage outflows and stimulate inflows. In the exchange crisis, the decision of sticking to the pegged system did not allow this mechanism.

In general, the literature has emphasized the role of short-term flows during the financial crises. In fact, in Brazil, FDI has been more stable than other flows. Nevertheless, debt securities, loans and trade credits with maturity superior to 360 days-classified as long-term flows-have exerted an important role during the crises as well. In the moments of crisis, long-term debt inflows tended to decline as much as short-term inflows. Actually, they may fall more as their horizon is longer and, therefore, are more sensitive to uncertainties. The difference, of course, is that, with longer-term debt, outflows are better distributed over time-lower repayments and pressure for debt rollover-tending to reduce net outflows in the short-run. However, 
the long-term category of the balance of payments statistics includes flows as short as one year, which are not enough to allow great extension of maturity.

"Other short-term assets" exerted an important role, mainly in the exchange crisis. In fact, $44.3 \%$ of the deficit of US\$ 25.1 billion in the private capital balance from 1998:8 through 1999:1 consisted of this category, which is related to the so-called CC5 accounts.

Sudden stops involve both the interruption of capital inflows and an increase in outflows. Figures 20.a to 20.c show the behavior of inflows and outflows of foreign investments in Brazilian corporate equities, debt securities, and long-term loans. In general, both inflows and outflows have played an important role. Outflows of investments in equities followed closely inflows, placing in evidence their short-term nature. The reduction in inflows was substantially higher in the exchange crisis and took place before any increase in outflows, which actually started declining as inflows reduced. In the case of debt securities, the fall in inflows was large during both domestic crises. Since outflows depend on the due dates, a decrease in inflows took place before an increase in outflows for both debt securities and long-term loans.

In sum, we find in this section that in general FDI flows tend to be more stable and less correlated to the other flows. Long-term debt flows worked as a stabilizing factor during external crises, but behaved pro-cyclically during domestic crises. Moreover, sudden stops are more pronounced when the crisis is mostly domestically driven.

\section{Capital flows and macroeconomic performance}

The analysis of capital flows in Brazil naturally brings about a set of important questions. What has been the role of capital flows in Brazil? What have capital flows financed? What is the relationship with other macroeconomic variables? This section deals with these questions.

Initially, we investigate whether capital flows have financed a change in reserves or the capital account balance. Thereafter, using the national accounts, we examine 
whether current account deficits have financed consumption or investment or even reflected greater deficit in income account.

What have capital flows financed? International reserves versus current account balance

Capital flows can be associated with the current account balance or changes in international reserves. In particular, positive net flows can be used to finance reserve accumulation or current account deficits. Figure 21 shows that short movements in capital flows have implied changes in reserves, whereas movements of lower frequency are associated with current account deficits. Using quarterly data, Table 8 records the correlation of private capital account with the current account balance and reserve changes for different periods. Private capital account and reserve changes are highly correlated contemporaneously. As expected, this correlation is higher in the 1992-1998 period-dominated by managed exchange systems - than in the floating exchange rate period. As reserves respond less, the contemporaneous correlation between capital flows and current account deficits is higher in the latter period. Likewise, the lagged and leading correlations are higher in the recent period. These results indicate that, during the floating exchange regime, capital flows have been associated with quicker and larger changes in the current account.

To have some indication of when net capital flows financed reserve accumulation versus current account deficits, we have calculated, for each year, the ratios of both reserve change and current account deficit to the capital and financial account balance (including errors and omissions). Figure 22 depicts the results for 1990-2003. The left axis shows the share of net flows used to finance current account deficits. Negative values correspond to years of positive current account balance (1992 and 2003), and values greater than $100 \%$ refer to periods of current account deficit and reduction in reserves (1991, 1997-1999). The values in the right axis-shown in inverse scale-represent the share of net flows that translated into reserve increases. Negative values refer to periods of a reduction in reserves. Note, however, that the figure shows only proportions and not the amount of the values involved. 
Capital flows were used basically to finance current account deficits, especially during the cycle from 1995 through 2002. The exception to the rule was from 1992 through 1994, when most of net flows were employed to finance reserve accumulation. Actually, as we can see in Figure 23, there was an intense process of reserve accumulation from 1992 through 1996. Reserves rose from US\$ 9.4 billion at end-1991 to US\$ 60.1 billion at end-1996, and were fundamental for the implementation of Real Plan. The other exception took place in 2003, eased by positive current account results. $^{33}$

What have capital flows financed? Consumption or investment?

After averaging $0.6 \%$ over 1990-1994, the current-account-deficit-to-GDP ratio rose by 2.8 percentage points in the 1995-1997 period, reaching $4.1 \%$ in the latter year. The high deficits continued in the following years, averaging 4.4\% over 1998-2001. They reverted in 2002, with a deficit of $1.2 \%$, and turned into surplus in the following years. This section uses the national accounts to have an indication of the main aggregate components that accounted for the deficits. National account statistics, however, have to be used with care because they do not necessarily reflect relationships of causality.

$$
\begin{aligned}
& \text { We use the well-known basic identities of the national accounts: }{ }^{34} \\
& \text { CA }=\mathrm{S}-\mathrm{I} \text {, } \\
& \text { GNDY = GDP + NYCT, } \\
& \mathrm{S}=\mathrm{GNDY}-\mathrm{C}, \\
& \mathrm{C}=\mathrm{Ch}+\mathrm{Cg},
\end{aligned}
$$

where $\mathrm{CA}=$ current account balance, $\mathrm{S}$ = gross domestic saving, $\mathrm{I}=$ investment, GNDY $=$ gross national disposable income, GDP $=$ gross domestic product, $\mathrm{NYCT}=$ net income from abroad and net current transfers, $\mathrm{C}=$ consumption, $\mathrm{Ch}=$ household consumption, and $\mathrm{Cg}=$ government consumption.

\footnotetext{
${ }^{33}$ During the 1980 s, the exception was 1984-1985, with high trade balance surpluses.

${ }^{34}$ See, for instance, IMF (1993).
} 
Tables 9 and 10 divide the current-account-deficit period into two phases: i) 1995-1997, characterized by a large increase in the deficit and in domestic expenditure rates; and ii) 1998-2001, featured by some increase in the deficit and by a prominent role of the deficit in the net income from abroad. We estimate the contribution of the variables to the increase in the current account deficit comparing the first phase to 1990-1994, and the second phase to the first one.

According to Table 9, the increase in the current account deficit in the first period corresponded to both an increase in the investment ratio and a reduction in domestic saving. The rise in the investment ratio responded for $43.2 \%$ of the deficit increase in the period. In contrast, in the second period, the reduction in domestic saving was accompanied by a decrease, at a lower value, in the investment ratio. Table 10 allows us to discriminate the elements behind the reduction in domestic saving.

The current-account-deficit cycle was accompanied by an increase of 2.1 p.p. in the consumption share in the GDP, which took place basically in 1995 and 1996, as we can see in Figure 24. ${ }^{35}$ In fact, under the point of view of the national accounts, consumption-household and government-accounted for the larger part (74.6\%) in the increase in the current account deficit. On the other hand, because the share of consumption is approximately four times higher than that of investment, the percentage increase in the consumption ratio was lower than that of investment $(2.7 \%$ against $5.9 \%$ ). The combination of an increase in investment and consumption comprised $117.8 \%$ of the deficit increase (net income from abroad contributed with $-17.8 \%$ ).

In the 1998-2001 period, however, it was an increase in the net income deficit that accounted for most of the increase in the current account deficit. Net-incomedeficit-to-GDP rose by 1.5 p.p., reflecting basically the debt accumulation and foreign investments of the previous period, besides some movements related to the domestic crises.

In summary, the role of net financial flows in the 1990s was to finance:

i) a strong accumulation of international reserves between 1992 and 1996;

\footnotetext{
${ }^{35}$ Note that the values in the right axis refer to the consumption ratio.
} 
ii) a large expansion of the current account deficit over 1995-1997, representing an expansion of both investment and consumption;

iii) an increase in the current account deficit over 1998-2001, resulting from a higher deficit in the net income from abroad.

GDP Growth

Since the 1980s, the Brazilian economy has experienced short-lived business cycles. Figure 25 shows the four-quarter-moving average of GDP growth and the fourquarter cumulative balance of the private capital account since 1992. Economic expansions have lasted approximately two years. The figure also shows that there is an association between capital flows and output movements. The two expansions before the adoption of the floating exchange rate regime benefited from the large capital inflows. Figure 3 shows clearly the appreciation trend and the large trade deficit of the period.

In comparison to the 1990s growth episodes, economic growth in 2000-2001 and at the present (2004) took place in a different context. First, net capital flows have been of a lower magnitude and have been dominated by FDI. Actually, since 1998, net direct investment has comprised more than $100 \%$ of the private capital account balance. There has been no significant surge of short-term flows or portfolio investment. Second, the expansions have been accompanied by a more favorable situation in the trade balance. Third, the policy regime has changed to improve fundamentals. Furthermore, the economic slowdown was less intense in the Brazilian confidence crisis than in other countries' sudden stop crises. Figure 26 shows GDP growth in the year following the crises for a few comparable cases.

\section{Consumption smoothing}

Based on the intertemporal approach to the current account, capital flows are deemed to bring about greater consumption smoothing. ${ }^{36}$ When facing idiosyncratic shocks, country's consumers can borrow (or lend) abroad and reduce consumption volatility. Table 11 shows consumption volatility for three periods. We compare

\footnotetext{
${ }^{36}$ See Obstfeld and Rogoff $(1994,1996)$.
} 
volatility after capital account openness with the periods of absence of capital flows and of the 1970s debt accumulation. In fact, consumption-its growth rate or share in GDP_is more stable in the recent period than in the 1980s. ${ }^{37}$ The standard deviation of consumption growth is also lower after the capital account liberalization in comparison to the 1970s, even though the variation coefficient is slightly higher because of the lower growth rate. ${ }^{38}$

\section{What determines capital flows and their components?}

To assess the main determinants of capital flows, we have estimated regressions for selected items: private capital account, official-agency-related loans, net foreign direct investment, and net foreign investment in debt securities, equities, and loans. In particular, we are interested in the role played by the external and domestic interest rates and the crises. The main results are recorded in Table 12. We have used as explanatory variables: Fed Funds interest rate, domestic interest rate minus expected depreciation, ${ }^{39}$ and EMBI+ Brazil (sovereign spread). Although the EMBI is also affected by the Fed Funds rate, it tends to reflect basically the several crises. The correlation coefficient between the Fed Funds rate and the EMBI is -0.208 . Thus, we do not include dummies for the crises, whose specification implies some arbitrariness and may distort the estimations. $^{40}$

\footnotetext{
${ }^{37}$ In contrast, Prasad et. al. (2003) have found that the median of the consumption volatility of 22 more financially integrated developing countries—which include Brazil-increased in the 1990s in comparison to the 1980s.

${ }^{38}$ One should be cautious about these comparisons because the periods may involve different moments in the cycle, and of course GDP has additional determinants. In particular, 1983-1991 was a period marked by the external adjustment resulting from the debt crisis and by the recession brought about by the Collor Plan in 1990. On the other hand, the 1970s was a period of great economic expansion, and the last decade was featured by several financial crises.

${ }^{39}$ Calculated using the Selic in the first working day of the month divided by the expected exchange rate change, measured as the ratio between the forward rate for contracts due at the beginning of the following month and the spot rate. All dependent variables are measured at constant U.S. prices.

${ }^{40}$ Initially, we have conducted unit root tests - augmented Dickey-Fuller formulation-basically to avoid incurring spurious regression. We reject the null for all dependent variables, except for direct investment. In the case of the regressors, we accept the null of presence of a unit root in the U.S. and domestic interest rates, and reject it for the EMBI. In the estimations, we have used two-stage-least squares, employing standard errors corrected by Newey-West heteroskedasticity and autocorrelation consistent covariance matrix. The instrument variables for domestic interest rate and the EMBI Brazil were these variables lagged one and two periods. We consider that the Fed Funds rate is not affected contemporaneously by shocks to capital flows to Brazil.
} 
The role played by the EMBI and the domestic interest rate is evident. In the regressions of the variables representing private capital flows, the EMBI enters significantly with a negative sign and the domestic interest rate with a positive sign, except in the case of direct investment. Greater yields in domestic bonds attract capital inflows, and financial crises stimulate net outflows. The Fed Funds rate enters significantly only in the equity and direct investment equations, but with a positive sign. One possible explanation is that increases in the U.S. interest rate tend to generate economic slowdown, discouraging investment in that country and thus stimulating investment abroad.

In contrast to the other private flows, the coefficient on the domestic interest rate is negative in the direct investment equation. In this case, as an increase in the domestic interest rate generates an economic slowdown, inward direct investment is discouraged. ${ }^{41}$ The equation for official-agency loans appears with a positive coefficient on the EMBI, indicating the role played by these loans in working as "compensatory flows" during some crises. ${ }^{42}$

The relationship between capital flows and macroeconomic performance: a VAR approach

We have estimated a structural vector autoregression to further examine the role played by capital flows. Our interest is to assess the importance and impact of capital flow movements on other macroeconomic variables as well as the factors behind those movements.

To estimate the VAR, we choose variables that are related to the behavior of the current account and capital flows: industrial production, current account balance, private capital account, terms of trade (measured as the ratio of export prices to import prices), EMBI+ Brazil, real effective exchange rate (measured as the value of foreign currency

\footnotetext{
${ }^{41}$ Since we could not reject the null of presence of a unit root in the direct investment, we have also estimated in first differences, after having rejected the presence of cointegration. None of the coefficients is significant.

${ }^{42}$ We have also tested for the inclusion of other variables, such as output-level and growth-and exchange rate-measured as deviation of a trend estimated using HP filter-but they did not enter significantly.
} 
in terms of domestic currency), and domestic real interest rate (Selic rate). The exogenous variables are the Fed Funds interest rate and the U.S. industrial production.

The sample goes from 1995:1 through 2004:8. Unfortunately, although we are using monthly data, some of the results are sensitive to the identification structure assumed concerning the contemporaneous effects of the shocks. Therefore, the results have to be seen with caution. Appendix D brings a more detailed explanation of the variables and identification structure used.

For simplicity, we show only the resulting impulse response functions and the variance error decomposition (Figure 27 and Table 13). In general, the results using the point estimates of the impulse response functions are consistent with the theory and historical evidence. The most interesting result refers to the behavior of the variables when the economy is hit by a shock to the EMBI. An increase in the country risk premium clearly leads to a positive response of interest rate, exchange rate depreciation (depreciation of domestic currency) and a reduction in capital flows (measured by the private capital account balance). Although with some lag, output falls. As exchange rate depreciates, terms of trade deteriorate. These results are in line with the historical evidence concerning the effects of several crises on the economy.

As expected, in response to positive interest-rate shocks, output falls. Positive shocks to the current account, in turn, lead to an exchange rate appreciation, reduction in the EMBI, and some improvement in terms of trade and output levels. Positive shocks to capital flows are not persistent but lead to a reduction in the interest rate, which seems to cause exchange rate depreciation. In response to a favorable shock to terms of trade, exchange rate tends to appreciate. Finally, positive shocks to the exchange rate are followed by an increase in the interest rate and EMBI. The increase in the country risk premium, in turn, tends to cause a reduction in the capital flows. Current account tends to respond somewhat positively. Output, however, declines, but reverts as the exchange rate, EMBI and interest rate return to their previous values.

The variance error decomposition allows us to have an idea of the importance of certain shocks for forecast errors. Shocks to current account, private capital account and exchange rate explain large part of output forecast errors in a 12 or 24-month horizon. 
Interest rate shocks affect output forecast errors more strongly in the short horizon. Private capital account forecast errors, in turn, are largely explained by shocks to the EMBI, exchange rate and interest rate. In the case of exchange rate, shocks to the country risk premium, private capital account and current account respond for large part of its forecast errors. Interest rate forecast errors, in turn, are explained by shocks to private capital account, terms of trade, EMBI and exchange rate, besides shocks to itself.

\section{Conclusions}

Notwithstanding the financial crises and macroeconomic volatility of the recent past, financial liberalization has led to reduced external vulnerability. Balance of payments patterns have changed. Recent growth has been accompanied by a more favorable trade balance position. The profile of external financing has improved after the floating of the currency. The private sector has decreased significantly its issuance of external debt and FDI has replaced portfolio investment as the main financing source.

Liberalization of the capital account in the last fifteen years has provided more convertibility to the currency. The new rules, however, coexist with an old legislation that was established in a more control-prone environment. Therefore, the result is a complex web of regulations and rules that require consolidation and a mentality that still associates transfers abroad with illicit or antipatriotic practices (based on the capital flight legislation period).

We believe further progress in capital account convertibility is warranted. Liberalization should be accompanied by a broad range of reforms to improve and foster stronger institutions-such as approval of de jure central bank independence (not only de facto)—establish a longer track record of responsible fiscal policy (under the fiscal responsibility law) and reduce microeconomic inefficiencies and contractual uncertainties.

\section{References}

Arida, Persio (2003a), "Por uma moeda plenamente conversível", Revista de Economia Política, 23(3): 151-154, Jul.-Sept. 
Arida, Persio (2003b), “Ainda sobre a conversibilidade”, Revista de Economia Política, 23(3): 135-142, Jul.-Sept.

Arida, Persio (2004), "Aspectos Macroeconômicos da Conversibilidade: uma Discussão do Caso Brasileiro", mimeo.

Arida, Persio, Edmar L. Bacha, and André Lara-Resende (2004), "Credit, interest, and jurisdictional uncertainty: conjectures on the case of Brazil", forthcoming in Giavazzi, Francesco, Ilan Goldfajn, and Santiago Herrera (eds.) (2005), Inflation targeting, debt and the Brazilian experience, 1999 to 2003, MIT Press.

Ariyoshi, Akira, Karl Habermeier, Bernard Laurens, Inci Otker-Robe, Jorge I. CanalesKriljenko, and Andrei Kirilenko (2000), "Capital controls: country experiences with their use and liberalization", IMF, Occasional Paper no. 190.

Banco Central do Brasil (1993), "O regime cambial brasileiro: evolução recente e perspectivas", Brasília, Banco Central do Brasil.

Banco Central do Brasil (2001), "Notas metodológicas do balanço de pagamentos", Notas Técnicas do Banco Central do Brasil no. 1, June.

Bosworth, Barry P., and Susan M. Collins (1999), "Capital flows to developing economies: implications for saving and investment", Brookings Papers on Economic Activity, 1999(1): 143-180.

Cardoso, Eliana, and Ilan Goldfajn (1998), "Capital flows to Brazil: the endogeneity of capital controls", IMF Staff Papers, 45(1), 161-202.

Carvalho, Bernardo S. de M. (2005), "A eficácia dos controles de entrada de capitais", Master's Thesis, PUC-Rio, mimeo.

Cerqueira, Ceres A. (2003), Dívida Externa Brasileira, 2nd ed., Brasília, Banco Central do Brasil.

Edwards, Sebastian (2005), "Capital controls, sudden stops and current account reversals", NBER, Working Paper no. 11170, Mar.

Ferrari Filho, Fernando, Frederico G. Jayme Jr., Gilberto T. Lima, José L. Oreiro and Luiz F. Paula (2005), "Uma avaliação crítica da proposta de conversibilidade plena do real", Revista de Economia Política, 25(1): 133-151, jan.-mar.

Franco, Gustavo H. B., and Demosthenes M. Pinho Neto (2004), “A desregulamentação da conta de capitais: limitações macroeconômicas e regulatórias”, PUC-RJ, Texto para Discussão no. 479, Jan. 
Garcia, Márcio G. P., and Alexandre Barcinski (1998), "Capital flows to Brazil in the nineties: macroeconomic aspects and the effectiveness of capital controls", Quarterly Review of Economics and Finance, 38(3): 319-357.

Garcia, Márcio G. P., and Marcus V. F. Valpassos (1998), "Capital flows, capital controls and currency crisis: the case of Brazil in the nineties”, PUC-RJ, Texto para Discussão no. 389, Nov.

Giavazzi, Francesco, Ilan Goldfajn, and Santiago Herrera (eds.) (2005), Inflation targeting, debt and the Brazilian experience, 1999 to 2003, MIT Press.

Gleizer, Daniel (ed.) (2005), Aprimorando o mercado de câmbio brasileiro, São Paulo, Bolsa de Mercadorias \& Futuros.

Hamilton, James D. (1994), Time Series Analysis, Princeton, Princeton University Press.

International Monetary Fund (1993), Balance of Payments Manual, Washington, D.C. International Monetary Fund, Annual Report on Exchange Arrangements and Exchange Restrictions, Washington, D.C., various issues.

Obstfeld, Maurice, and Kenneth Rogoff (1994), "The intertemporal approach to the current account”, NBER, Working Paper no. 4893, Oct.

Obstfeld, Maurice, and Kenneth Rogoff (1996), Foundations of International Macroeconomics, MIT Press, Cambridge, MA.

Prasad, Eswar, Kenneth Rogoff, Shang-Jin Wei, and M. Ayhan Kose (2003), "Effects of financial globalization on developing countries: some empirical evidence", IMF, Occasional Paper no. 220, Mar.

Schwartsman, Alexandre (2004), "Descontrole nas contas CC5", Valor Econômico, 8.30.04.

Sims, Christopher A., James H. Stock, and Mark W. Watson (1990), "Inference in Linear Time Series Models with Some Unit Roots", Econometrica, vol. 58, no. 1, pp. 113-144, Jan.

Soihet, Elena (2002), "Índice de controle de capitais: uma análise da legislação e dos determinantes do fluxo de capital no período 1990-2000”, EPGE-FGV, Master's Thesis, June.

Stiglitz, Joseph (2002), Globalization and its discontents, W.W. Norton, New York and London. 


\section{Appendix A: Main exchange restrictions in Brazil}

\section{Export Surrender}

- Export proceeds are required to be converted into domestic currency ("exports surrender"). Furthermore, the netting of payments is not allowed, e.g., exporters cannot use their proceeds to pay for an import or an external debt before converting them into domestic currency.

\section{Controls on capital flows}

- There are generally no current taxes on capital flows. Two exceptions. Shortterm fixed income flows (up to 90 days) are taxed at a 5\% rate. Payments of credit card transactions are taxed at $2 \%$.

- All capital flows must be registered at the Central Bank of Brazil

\section{Transfers of currency}

- Transfers abroad by residents are allowed but have to be registered at the Central Bank.

- Travelers may take out or bring into the country domestic or foreign banknotes, checks, or traveler's checks without restriction but must declare to customs any amount over $\mathrm{R} \$ 10,000$ or its equivalent.

\section{Limits on transactions and deposits in foreign currency}

- Settlements of transactions among residents and pricing of contracts or goods in foreign currency is prohibited.

- Lending in foreign currency is prohibited, except for onlending of external foreign currency loans by banks.

- Deposits in foreign currency are generally not allowed. There are several exceptions. Residents: authorized foreign exchange dealers, tourist agencies, Brazilian citizens living abroad, the Brazilian Post Office Administration, credit card administration companies, companies responsible for the development and execution of projects in the energy sector, and insurance and reinsurance companies and reinsurance brokers. Nonresidents: embassies, foreign delegations, international organizations, foreign transportation companies, foreign citizens in transit in the country, and reinsurance companies.

\section{Direct Investment}

- Foreign direct investment in Brazil is generally free. However, there are legal restrictions on participation in certain economic activities.

- Brazilian direct investment abroad requires prior approval by the Central Bank. The exception is transfers of up to the equivalent of US\$5 million, including all remittances in the previous 12 months.

\section{Nonresident participation in local markets}

- No restriction on purchase of debt instruments. Purchase by nonresident of 
shares is also generally free. There are restrictions in certain economic activities.

- Nonresident may issue shares (or other securities that represent ownership) only through Brazilian Depositary Receipts (BDRs). The exception is for MERCOSUR countries, where direct sales are also allowed.

\section{Resident restrictions on investment and issues abroad}

- Residents may purchase bonds or other debt securities through dedicated offshore investment funds (FIEX).

- Residents may invest only in stock exchanges in MERCOSUR countries. Brazilians are allowed to purchase Depositary Receipts issued abroad by companies headquartered in Brazil.

- Corporations may issue Depositary Receipts abroad. 
Appendix B: Cronology of main changes to capital account regulation (1990-2004) ${ }^{(*)}$

Resident and nonresident accounts

\begin{tabular}{llll}
\hline Normative & Date & $\mathrm{N}^{(1)} \mathrm{D}^{(2)}$ & Description \\
\hline
\end{tabular}

Regulation implemented prior to the 1990s

$\begin{array}{ll}\text { Decree } 23,501 \text {, replaced } & 11.27 .33 \\ \text { by Decree-Law } 857 & 9.11 .69\end{array}$
Decree 55,762

Circular Letter 5

Resolution 1,552

12.22 .88
Decree 42,820

Establishment of the domestic currency as the only legal tender. In other words, payments in foreign currency are not allowed (exceptions included contracts related to imports and exports, exchange contracts, and debt involving nonresidents as creditor or debtor). Law 10,192, 2.14.01 (previously Provisory Measure 1,053, 6.30.95), reaffirmed those restrictions, and also clarified that restriction includes indexation to a foreign currency.

Determination that "it is permissible to take out or bring in domestic and foreign paper currency, as well as stocks and any other financial assets that have monetary value" (article 17). The National Monetary Council $(\mathrm{CMN})$, if necessary, can restrict the entry and exit of domestic paper money (article 20).

Permission for nonresidents to transfer abroad, without prior authorization, the balance resulting from foreign exchange sales or money orders in foreign currency (article 57).

Classification of nonresidents' deposit accounts into two categories: i) "free accounts - coming from exchange sales", and ii) "free accounts from other origins". The balance of the former that is not withdrawn is freely convertible into foreign currency; however, if the balance is withdrawn and then subsequently returned to the account, it is classified in the second category.

Creation of the "floating exchange rate market"-also called "dollartourism market"-alongside the "commercial or free exchange rate market". Permission for authorized institutions to transfer their long foreign currency position to nonresident institutions in exchange for domestic currency. Furthermore, permission for the Central Bank to change the conditions of the floating exchange rate market at any time.

\section{Main changes}

Circular Letter 2,259

2.20 .92

L O Creation of a third category in the free accounts established in Circular Letter 5, complementing Resolution 1,552: "free accounts - financial institutions - floating exchange rate market", which can be opened by nonresident financial institutions and whose withdrawals and deposits are freely available, including those coming from exchange sales or purchases.

Resolution 1,946, Circular 7.29.92, 2,242 10.7.92

Circular 2,677, Circular 2,242

4.10.96, 10.7.92
R O Requirement that international transfers in domestic currency should be identified and registered in the Central Bank Information System (Sisbacen), when equal to or greater than US\$10,000.00.

E O Consolidation and revision of the regulation on nonresidents' accounts and international transfers in reais. Requirement of Sisbacen identification when withdrawals or deposits are equal to or greater than $R \$ 10,000.00$ (revoked Circular Letter 5).

Notes: In this table, we focus on the so-called CC5 accounts.

${ }^{(1)} \mathrm{L}, \mathrm{R}$ and $\mathrm{E}$ refer to liberazing, restrictive and regulatory measures, respectively.

(2) I and $O$ refer to related to measures to inflows and outflows, respectively.

${ }^{*}$ ) We focus on regulation of capital account and convertibility of domestic currency into foreign currency. Thus, we do not deal, for example, with export and import payments. Resolutions are rules set by the National Monetary Council; circulars, circular letters and communications by the Central Bank of Brazil; and directives by the Ministry of Finance. This chronology was written consulting directly the rules, but using initially IMF, Annual Report on Exchange Arrangements and Exchange Restrictions, and Soheit (2002). 
Foreign direct investment

\begin{tabular}{|c|c|c|c|}
\hline Normative & Date & $N^{(1)} D^{(2)}$ & Description \\
\hline \multicolumn{4}{|l|}{$\begin{array}{l}\text { Regulation implemented } \\
\text { prior to the } 1990 \text { s }\end{array}$} \\
\hline $\begin{array}{l}\text { Law } 4,131, \text { Law } 4,390 \text { and } \\
\text { Decree } 55,762\end{array}$ & $\begin{array}{l}9.3 .62 \\
8.29 .64 \\
2.17 .65\end{array}$ & & $\begin{array}{l}\text { Regulation of foreign capital in Brazil, basically direct investment and } \\
\text { loans, and the associated remittance of income abroad. }\end{array}$ \\
\hline Resolution 1,460 & 2.1 .88 & & $\begin{array}{l}\text { Regulation of the conversion of external debt into investment in the } \\
\text { country. }\end{array}$ \\
\hline Constitution & 10.5 .88 & & Restriction on foreign investment in some economic sectors. \\
\hline \multicolumn{4}{|l|}{ Main changes } \\
\hline Resolution 1,810 & 3.27 .91 & L I & $\begin{array}{l}\text { Authorization of the conversion of external debt instruments of the federal } \\
\text { public sector, bonds, and deposits denominated in foreign currency for } \\
\text { use in the National Privatization Program. }\end{array}$ \\
\hline Law 8,383 & 12.30 .91 & L O & $\begin{array}{l}\text { Elimination of the additional tax, ranging from } 40 \% \text { to } 60 \% \text {, on remittance } \\
\text { of profits and dividends abroad that exceeded } 12 \% \text { of registered capital - } \\
\text { effective } 1.1 .92 \text {. Reduction to } 15 \% \text { of the withholding tax on profits and } \\
\text { dividends of nonresidents - effective } 1.1 .93 \text {. }\end{array}$ \\
\hline Resolution 1,894 & 1.9 .92 & L I & $\begin{array}{l}\text { Reduction from twelve to six years of the period that investments resulting } \\
\text { from the conversion of external debt instruments for use in the National } \\
\text { Privatization Program are required to remain in Brazil. }\end{array}$ \\
\hline Circular 2,487 & 10.5 .94 & R I & $\begin{array}{l}\text { Prohibition of inflows in the form of both advances for future capital } \\
\text { increases and bridge investments in anticipation of future conversion of } \\
\text { debts into investment. }\end{array}$ \\
\hline Law 8,987 & 2.13 .95 & L I & $\begin{array}{l}\text { Opening of new possibilities for investment in public utilities with the } \\
\text { Concession Law. }\end{array}$ \\
\hline $\begin{array}{l}\text { Constitutional } \\
\text { Amendment } 6\end{array}$ & 8.15 .95 & L I & $\begin{array}{l}\text { Removal of the constitutional distinction between Brazilian } \\
\text { firms-licensed under Brazilian laws and with headquarters and } \\
\text { administration in the country-and Brazilian firms of national } \\
\text { capital-restricted to those under control of residents-and the related } \\
\text { special treatment given to the latter. Regardless of owner nationality, firms } \\
\text { licensed under Brazilian laws and with headquarters and administration in } \\
\text { the country were guaranteed: i) special treatment in the case of small } \\
\text { firms; and ii) exclusivity rights in the mining sector. }\end{array}$ \\
\hline $\begin{array}{l}\text { Constitutional } \\
\text { Amendment } 7\end{array}$ & 8.15 .95 & L I & $\begin{array}{l}\text { Removal of the constitutional requirement that navigation along the coast } \\
\text { and in the inland waterways be conducted by national vessels. }\end{array}$ \\
\hline $\begin{array}{l}\text { Statement of Reasons } 311, \\
\text { Communications } 5,796 \\
\text { and } 10,844\end{array}$ & $\begin{array}{l}\text { 8.23.95, } \\
9.9 .97 \\
3.19 .03\end{array}$ & L I & $\begin{array}{l}\text { Possibility for an increase in the ownership participation of nonresidents in } \\
\text { financial institutions, after case-by-case analysis by the monetary } \\
\text { authority, and Republic President's final decision. }\end{array}$ \\
\hline Law 9,249 & 12.26 .95 & L $\quad O$ & $\begin{array}{l}\text { Removal of income tax, previously of } 15 \% \text {, on remittance of profits and } \\
\text { dividends abroad. }\end{array}$ \\
\hline Directive MF 28 & 2.8 .96 & R I & $\begin{array}{l}\text { Imposition of a financial transaction tax (IOF) of } 5 \% \text { on privatization } \\
\text { funds, when the resources enter the country. }\end{array}$ \\
\hline Directive MF 85 & 4.24 .97 & L I & $\begin{array}{l}\text { Reduction in the financial transaction tax (IOF) from } 5 \% \text { to } 0 \% \text { on } \\
\text { privatization funds. }\end{array}$ \\
\hline Circular 2,997 & 8.15 .00 & $\mathrm{E}$ & Introduction of electronic registration (RDE) for foreign direct investment. \\
\hline Resolution 2,815 & 1.24 .01 & L I & $\begin{array}{l}\text { Revocation of rule set in Resolution } 2,099,8.17 .94 \text {, which precluded the } \\
\text { opening of new bank branches controlled by nonresidents. }\end{array}$ \\
\hline
\end{tabular}

(1) $\mathrm{L}, \mathrm{R}$ and $\mathrm{E}$ refer to liberazing, restrictive and regulatory measures, respectively.

(2) I and $O$ refer to related to measures to inflows and outflows, respectively. 
Foreign portfolio investment and external loans

\begin{tabular}{|c|c|c|c|}
\hline Normative & Date & $N^{(1)} D^{(2)}$ & Description \\
\hline \multicolumn{4}{|l|}{$\begin{array}{l}\text { Regulation implemented } \\
\text { prior to the } 1990 \text { s }\end{array}$} \\
\hline $\begin{array}{l}\text { Law } 4,131 \text { and } 4,390 \\
\text { Decree } 55,762\end{array}$ & $\begin{array}{l}\text { 9.3.62, } \\
8.29 .64 \\
2.17 .65\end{array}$ & & $\begin{array}{l}\text { Regulation of foreign capital in Brazil, basically direct investment and } \\
\text { loans, and the associated remittance of income abroad. }\end{array}$ \\
\hline Resolution 63 & 8.21 .67 & & $\begin{array}{l}\text { Regulation of external loans that are on-lent by resident financial } \\
\text { institutions. }\end{array}$ \\
\hline Resolution 64 & 8.23 .67 & & $\begin{array}{l}\text { Inclusion of BNDES among the institutions authorized to on-lend loans } \\
\text { under Resolution } 63 .\end{array}$ \\
\hline Resolution 125 & 12.12 .69 & & Requirement that external loans be previously approved by the BCB. \\
\hline Resolution 498 & 11.22 .78 & & $\begin{array}{l}\text { Determination of a minimum maturity of ten years for external loans to be } \\
\text { eligible for reimbursement, reduction or exemption from income tax. }\end{array}$ \\
\hline Resolution 644 & 10.22 .80 & & $\begin{array}{l}\text { Exemption from tax on the remittance abroad of interest, commission and } \\
\text { issuance expenditures of commercial paper. }\end{array}$ \\
\hline $\begin{array}{l}\text { Resolution } 1,289 \text {, with } \\
\text { Annexes I to III }\end{array}$ & 3.20 .87 & & $\begin{array}{l}\text { Regulation of the creation, operation, and management of foreign capital } \\
\text { investment companies, foreign capital investment funds, and stock and } \\
\text { bond portfolios. }\end{array}$ \\
\hline Resolution 1,460 & 2.1 .88 & & $\begin{array}{l}\text { Regulation of the conversion of external debt into investment in the } \\
\text { country. }\end{array}$ \\
\hline \multicolumn{4}{|l|}{ Main changes } \\
\hline Resolution 1,734 & 7.31 .90 & L I & $\begin{array}{l}\text { Authorization for certain financial institutions to issue commercial paper } \\
\text { abroad. }\end{array}$ \\
\hline Resolution 1,803 & 3.27 .91 & L I & $\begin{array}{l}\text { Reduction in the minimum maturity of external loans from ten to five years } \\
\text { for those to be eligible for reimbursement, reduction or exemption from } \\
\text { income tax (revoked Resolution 498). }\end{array}$ \\
\hline Debt Agreement & 4.1 .91 & $E$ & $\begin{array}{l}\text { Preliminary agreement with nonresident creditor banks for the elimination } \\
\text { of arrears outstanding at the end of } 1990 \text {. }\end{array}$ \\
\hline Resolution 1,832 & 5.31 .91 & L I & $\begin{array}{l}\text { Liberalization of the securities market to foreign institutional investors, via } \\
\text { Annex IV to Resolution } 1,289 \text {. These investments were given exempted } \\
\text { from income and capital gains tax, but subject to a } 15 \% \text { tax on income } \\
\text { remitted abroad. }\end{array}$ \\
\hline $\begin{array}{l}\text { Circular } 1,969 \text {, replaced by } \\
\text { Circular } 2,199\end{array}$ & $\begin{array}{l}\text { 6.6.91, } \\
7.16 .92\end{array}$ & L I & Authorization for the issuance of convertible debentures abroad. \\
\hline Resolution 1,853 & 7.31 .91 & $\mathrm{~L} \quad \mathrm{O}$ & $\begin{array}{l}\text { Tax exemption for the remittance abroad of interest, commission and } \\
\text { issuance expenditures, applied to commercial paper, extended to floating } \\
\text { rate notes, fixed rate notes, floating rate certificates of deposit, fixed rate } \\
\text { certificates of deposit, publicly-issued bonds, and private issued bonds. }\end{array}$ \\
\hline $\begin{array}{l}\text { Resolution } 1,848 \text {, replaced } \\
\text { by Resolution } 1,927\end{array}$ & $\begin{array}{l}\text { 8.1.91, } \\
5.18 .92\end{array}$ & L I & $\begin{array}{l}\text { Authorization for the issuance abroad of Depository Receipts representing } \\
\text { Brazilian securities (American Depositary Receipts - ADRs, and } \\
\text { International Depositary Receipts - IDRs) - Annex V. }\end{array}$ \\
\hline Resolution 1,872 & 9.25 .91 & L I & Permission for external borrowing for agricultural financing. \\
\hline Circular 2,083 & 11.7.91 & L I & $\begin{array}{l}\text { Reduction in the minimum term for on-lending opera-tions related to } \\
\text { Resolution } 63 \text { from one year (investment banks and BNDES) or six } \\
\text { months (commercial banks) to } 90 \text { days. }\end{array}$ \\
\hline Resolution 1,901 & 1.29 .92 & $\mathrm{~L}$ & $\begin{array}{l}\text { Authorization for natural and juridical persons to invest in securities in } \\
\text { Mercosur countries. }\end{array}$ \\
\hline
\end{tabular}


Foreign portfolio investment and external loans (continued)

\begin{tabular}{|c|c|c|c|c|}
\hline Normative & Date & $\mathrm{N}^{(1}$ & $D^{(2)}$ & Description \\
\hline $\begin{array}{l}\text { Communications } 2,747 \\
\text { and } 2,757\end{array}$ & $\begin{array}{l}3.12 .92 \\
3.13 .92\end{array}$ & $\mathrm{R}$ & I & $\begin{array}{l}\text { Increase in the minimum average maturity of debt securities (commercial } \\
\text { paper and those listed in Resolution } 1,853,7.31 .91 \text { ) to } 30 \text { months to be } \\
\text { eligible for tax exemptions. }\end{array}$ \\
\hline Circular Letter 2,269 & 4.24 .92 & $\mathrm{R}$ & I & $\begin{array}{l}\text { Requirement that the minimum average maturity for issuance of debt } \\
\text { securities must be } 30 \text { months, and increase, from } 30 \text { to } 60 \text { months, in the } \\
\text { minimum average maturity required for those to be eligible for tax } \\
\text { exemptions (revoked Communications } 2,747 \text { and } 2,757 \text { ). }\end{array}$ \\
\hline Resolution 1,921 & 4.30 .92 & $\mathrm{~L}$ & & $\begin{array}{l}\text { Authorization for hedge operations against interest rate risk in the } \\
\text { international market. }\end{array}$ \\
\hline Resolution 1,935 & 6.30 .92 & $\mathrm{~L}$ & I & $\begin{array}{l}\text { Authorization for foreign investors represented by funds, investment } \\
\text { companies, and institutional investors to operate in the options and } \\
\text { futures markets for securities, exchange, and interest rates. }\end{array}$ \\
\hline Resolution 1,968 & 8.30 .92 & $\mathrm{~L}$ & & $\begin{array}{l}\text { Authorization for natural and juridical persons to invest in derivatives } \\
\text { markets as hedge operations in Mercosur countries (replaced Resolution } \\
1,901 \text { ). }\end{array}$ \\
\hline Circular Letter 2,333 & 10.29 .92 & $\mathrm{R}$ & 1 & $\begin{array}{l}\text { Authorization for external loans only for those with a minimum average } \\
\text { maturity of } 30 \text { months. }\end{array}$ \\
\hline Circular Letter 2,372 & 6.16 .93 & $\mathrm{R}$ & I & $\begin{array}{l}\text { Increase in both the minimum average maturity required for the issuance } \\
\text { of debt securities from } 30 \text { to } 36 \text { months, and in the minimum average } \\
\text { maturity from } 60 \text { to } 96 \text { months for eligibility for reimbursement, reduction } \\
\text { or exemption from income tax (revoked Circular Letter } 2,269 \text { ). }\end{array}$ \\
\hline Circular Letter 2,373 & 6.16 .93 & $\mathrm{R}$ & I & $\begin{array}{l}\text { Increase in the minimum average maturity required for loans from } 30 \text { to } \\
36 \text { months (revoked Circular Letter } 2,333 \text { ). }\end{array}$ \\
\hline Resolution 1,986 & 6.28 .93 & $\mathrm{R}$ & I & $\begin{array}{l}\text { Increase in the minimum average maturity of loans from } 60 \text { to } 96 \text { months } \\
\text { for those to be eligible for reimbursement, reduction or exemption from } \\
\text { income tax (revoked Resolution } 1,803 \text { ). }\end{array}$ \\
\hline Resolution 2,012 & 7.30 .93 & $\mathrm{~L}$ & & $\begin{array}{l}\text { Expansion of the hedge operations that firms are allowed to undertake, } \\
\text { including, besides those related to interest rates previously allowed, those } \\
\text { related to exchange rate and commodity prices (revoked Resolution } \\
1,921 \text { ). }\end{array}$ \\
\hline Resolution 2,013 & 8.19 .93 & $\mathrm{R}$ & I & $\begin{array}{l}\text { Prohibition of foreign capital, registered under Annexes I to IV, to invest in } \\
\text { fixed-income bonds. }\end{array}$ \\
\hline Decree 995 & 11.25 .93 & $\mathrm{R}$ & I & $\begin{array}{l}\text { Imposition of a financial transaction tax (IOF) of } 5 \% \text { on investments in } \\
\text { fixed-income funds and } 3 \% \text { on external loans when entering the country. }\end{array}$ \\
\hline Resolution 2,028 & 11.25 .93 & $\mathrm{R}$ & I & $\begin{array}{l}\text { Prohibition of foreign capital, registered under Annexes I to IV, to invest in } \\
\text { debentures, accompanied by the creation of foreign capital fixed-income } \\
\text { funds - FRF-CE, to invest in private debt securities. Portfolio investment } \\
\text { by foreign investors in fixed-income instruments was restricted to those } \\
\text { new funds. }\end{array}$ \\
\hline Circular 2,384 & 11.26 .93 & $\mathrm{~L}$ & I & $\begin{array}{l}\text { In the absence of objection by the Central Bank of Brazil, automatic } \\
\text { authorization for the issuance of debt securities by the private sector after } \\
\text { five working days of the request for authorization. }\end{array}$ \\
\hline Resolution 2,034 & 12.17 .93 & $\mathrm{R}$ & I & $\begin{array}{l}\text { Prohibition of foreign capital, registered under Annexes I to IV, to invest in } \\
\text { derivatives markets-unless as a hedge-including operations that result } \\
\text { in fixed income. FRF-CE funds were allowed to invest in federal bonds, } \\
\text { derivatives and in Financial Investment Funds - FAF (revoked Resolution } \\
2,028 \text { ). }\end{array}$ \\
\hline
\end{tabular}


Foreign portfolio investment and external loans (continued)

\begin{tabular}{|c|c|c|c|c|}
\hline Normative & Date & $\mathrm{N}^{\prime}$ & $D^{(2)}$ & Description \\
\hline Resolution 2,042 & 1.13 .94 & $\mathrm{~L}$ & & $\begin{array}{l}\text { Authorization for certain institutions to conduct swap operations involving } \\
\text { gold, exchange rates, interest rates, and price indices in the over-the- } \\
\text { counter market. }\end{array}$ \\
\hline Resolution 2,046 & 1.19 .94 & $\mathrm{R}$ & I & $\begin{array}{l}\text { Change in the regulation of investments under annexes I to IV, including } \\
\text { prohibition of investment in debentures (revoked Resolution } 2,013 \text { ). }\end{array}$ \\
\hline Circular 2,410 & 3.2 .94 & $\mathrm{R}$ & I & $\begin{array}{l}\text { Termination of the automatic authorization for the issuance of debt } \\
\text { securities abroad that had been set by Circular } 2,384,11.26 .93 \text {. }\end{array}$ \\
\hline Circular Letter 2,444 & 3.14 .94 & $\mathrm{R}$ & I & $\begin{array}{l}\text { Renewal or extension of contracts of debt securities subject to the same } \\
\text { rules as new contracts established by Circular Letter } 2,372,6.16 .93 \text {. }\end{array}$ \\
\hline Debt Agreement & 4.15 .94 & $E$ & & $\begin{array}{l}\text { Conclusion of the arrangements to reschedule Brazil's external debts to } \\
\text { commercial bank creditors. }\end{array}$ \\
\hline Resolution 2,079 & 6.15 .94 & $\mathrm{R}$ & I & $\begin{array}{l}\text { Prohibition of foreign capital, registered under Annexes I to IV, to invest in } \\
\text { certificates of privatization and related securities. }\end{array}$ \\
\hline Resolution 2,105 & 8.31 .94 & $\mathrm{~L}$ & $\mathrm{O}$ & Permission for prepayment of external loans and import financing. \\
\hline Resolution 2,115 & 10.19 .94 & $\mathrm{R}$ & I & $\begin{array}{l}\text { Prohibition of foreign capital, registered under Annexes I to IV, to invest in } \\
\text { Financial Investment Funds - FAF. }\end{array}$ \\
\hline Directive MF 534 & 10.19 .94 & $\mathrm{R}$ & I & $\begin{array}{l}\text { Increase in the financial transaction tax (IOF) from } 5 \% \text { to } 9 \% \text { on foreign } \\
\text { investment in fixed-income funds, and from } 3 \% \text { to } 7 \% \text { on external loans, } \\
\text { and imposition of a tax of } 1 \% \text { on foreign investment in securities. }\end{array}$ \\
\hline Circular 2,492 & 10.19 .94 & $\mathrm{R}$ & I & $\begin{array}{l}\text { Increase in the minimum maturity for on-lending operations under } \\
\text { Resolution } 63 \text { from } 90 \text { to } 540 \text { days (revoked Circular } 2,083 \text { ). }\end{array}$ \\
\hline Circular 2,545 & 3.9 .95 & $\mathrm{~L}$ & I & $\begin{array}{l}\text { Reduction in the minimum term for on-lending operations related to } \\
\text { Resolution } 63 \text { from } 540 \text { days to } 90 \text { days (revoked Circular } 2,492 \text { ). }\end{array}$ \\
\hline Circular 2,546 & 3.9 .95 & $\mathrm{~L}$ & I & $\begin{array}{l}\text { Reduction in the minimum average maturity required for loans from } 36 \text { to } \\
24 \text { months, with maintenance of the minimum average maturity of } 96 \\
\text { months for those to be eligible for reimbursement, reduction or exemption } \\
\text { from income tax (revoked Circular Letters } 2,372 \text { and } 2,373 \text { ). }\end{array}$ \\
\hline $\begin{array}{l}\text { Circular 2,547, replaced by } \\
\text { Circular } 2,559\end{array}$ & $\begin{array}{l}3.9 .95 \\
4.20 .95\end{array}$ & $\mathrm{~L}$ & 1 & $\begin{array}{l}\text { Reduction in the minimum average maturity required for the renewal and } \\
\text { extension of debt securities contracts from } 36 \text { months to } 180 \text { days, with } \\
\text { maintenance of the minimum average maturity of } 96 \text { months for eligibility } \\
\text { for reimbursement, reduction or exemption from income tax (revoked } \\
\text { Circular Letter 2,444). }\end{array}$ \\
\hline Directive MF 95 & 3.9 .95 & $\mathrm{~L}$ & I & $\begin{array}{l}\text { Reduction in the financial transaction tax (IOF) from } 9 \% \text { to } 5 \% \text { on foreign } \\
\text { investment in fixed-income funds, from } 1 \% \text { to } 0 \% \text { on foreign investment in } \\
\text { securities, and from } 7 \% \text { to } 0 \% \text { on external loans. }\end{array}$ \\
\hline Resolution 2,147 & 3.9 .95 & $\mathrm{R}$ & $\mathrm{O}$ & $\begin{array}{l}\text { Revocation of the permission for prepayment of external loans and import } \\
\text { financing (revoked Resolution 2,105). }\end{array}$ \\
\hline Resolution 2,148 & 3.16 .95 & $\mathrm{~L}$ & I & $\begin{array}{l}\text { Permission for external borrowing for the financing of agricultural } \\
\text { investment. Minimum maturity for these external loans of } 180 \text { days } \\
\text { (revoked Resolution 1,872). }\end{array}$ \\
\hline Resolution 2,170 & 6.30 .95 & $\mathrm{~L}$ & I & $\begin{array}{l}\text { Permission for financial institutions to contract resources abroad, with a } \\
\text { minimum maturity of } 720 \text { days, for the financing of construction or } \\
\text { acquisition of new real estate ventures. }\end{array}$ \\
\hline
\end{tabular}




\section{Foreign portfolio investment and external loans (continued)}

\begin{tabular}{|c|c|c|c|c|}
\hline Normative & Date & $\mathrm{N}^{1}$ & $D^{(2)}$ & Description \\
\hline Directive MF 202 & 8.10 .95 & $\mathrm{R}$ & (1) & $\begin{array}{l}\text { Increase in the financial transaction tax (IOF) from } 5 \% \text { to } 7 \% \text { on foreign } \\
\text { investment in fixed-income funds, and from } 0 \% \text { to } 5 \% \text { on external loans, } \\
\text { and imposition of a } 7 \% \text { rate on interbank foreign exchange operations } \\
\text { between financial institutions abroad and institutions authorized to operate } \\
\text { in the foreign exchange market, and on the formation of short-term cash } \\
\text { holdings ("disponibilidades") of nonresidents. }\end{array}$ \\
\hline Directive MF 228 & 9.15 .95 & $\mathrm{~L}$ & 1 & $\begin{array}{l}\text { Imposition of a differentiated financial transaction tax (IOF) on external } \\
\text { loans according to average maturity: } 5 \% \text { for those with an average } \\
\text { maturity of two years, } 4 \% \text { for three years, } 2 \% \text { for four years, } 1 \% \text { for five } \\
\text { years, and } 0 \% \text { for six years. }\end{array}$ \\
\hline Resolution 2,188 & 10.8 .95 & $\mathrm{R}$ & 1 & $\begin{array}{l}\text { Prohibition of foreign capital, registered under Annexes I to IV, to invest in } \\
\text { futures and options markets (revoked Resolution 2,115). }\end{array}$ \\
\hline Circular 2,661 & 2.8 .96 & $\mathrm{R}$ & I & $\begin{array}{l}\text { Increase in the minimum average maturity required for external credits to } \\
36 \text { months, with maintenance of the minimum average maturity of } 96 \\
\text { months for debt securities to be eligible for reimbursement, reduction or } \\
\text { exemption from income tax (revoked Circulars } 2,546 \text { and } 2,559 \text { ). }\end{array}$ \\
\hline Resolution 2,246 & 2.8 .96 & $\mathrm{R}$ & I & $\begin{array}{l}\text { Prohibition of foreign capital, registered under Annexes I to IV, to invest in } \\
\text { Agrarian Debt Bonds (TDA), National Development Fund Bonds (OFND) } \\
\text { and Siderbras debentures (revoked Resolution 2,188). }\end{array}$ \\
\hline Resolution 2,247 & 2.8 .96 & $\mathrm{~L}$ & 1 & $\begin{array}{l}\text { Permission for nonresidents to invest in Mutual Investment Funds in } \\
\text { Emerging Firms. }\end{array}$ \\
\hline Resolution 2,248 & 2.8 .96 & $\mathrm{~L}$ & 1 & Permission for nonresidents to invest in Real Estate Investment Funds. \\
\hline Resolution 2,266 & 3.29 .96 & $\mathrm{~L}$ & I & $\begin{array}{l}\text { Expansion of permission for external borrowing to finance agricultural } \\
\text { activities to all financial institutions, not only those participating of the } \\
\text { national system of rural credit. }\end{array}$ \\
\hline Resolution 2,271 & 4.18.96 & $\mathrm{R}$ & I & $\begin{array}{l}\text { Restriction of external financing for states, Federal District and } \\
\text { municipalities, and their dependencies, foundations and firms, to the } \\
\text { refinancing of their domestic debt. }\end{array}$ \\
\hline Resolution 2,280 & 5.22 .96 & $\mathrm{~L}$ & I & $\begin{array}{l}\text { Establishment of some exceptions to the restrictions set in Resolution } \\
2,271 \text { (revoked Resolution 2,271). }\end{array}$ \\
\hline Directive MF 241 & 10.31 .96 & $\mathrm{~L}$ & I & $\begin{array}{l}\text { Reduction in the differentiated financial transaction tax (IOF) on external } \\
\text { loans according to average maturity: } 3 \% \text { for those with an average } \\
\text { maturity less than three years, } 2 \% \text { for four years, } 1 \% \text { for five years, and } \\
0 \% \text { for equal to or above five years. }\end{array}$ \\
\hline $\begin{array}{l}\text { Resolution } 2,337 \text { and } \\
\text { Circular } 2,728\end{array}$ & $\begin{array}{l}11.28 .96 \\
11.28 .96\end{array}$ & $\mathrm{E}$ & & $\begin{array}{l}\text { Introduction of electronic registration (RDE) for inward and outward flows, } \\
\text { starting with foreign portfolio investment. }\end{array}$ \\
\hline Resolution 2,345 & 12.19 .96 & $\mathrm{~L}$ & 1 & $\begin{array}{l}\text { Authorization for the issuance abroad of Depository Receipts representing } \\
\text { non-voting shares of resident financial institutions with shares traded in } \\
\text { the stock market - Annex V. }\end{array}$ \\
\hline Law 9,430 & 12.27 .96 & $\mathrm{E}$ & & $\begin{array}{l}\text { Revocation of the decrees that gave authority to the National Monetary } \\
\text { Council to set some rules on nonresident income tax. As a consequence, } \\
\text { termination of tax rules set in Resolution } 1,853 \text {, and Circulars } 2,546 \text { and } \\
2,661 \text {. }\end{array}$ \\
\hline $\begin{array}{l}\text { Provisory Measure } 1,563 \text {, } \\
\text { turned into Law } 9,481\end{array}$ & $\begin{array}{l}12.31 .96 \\
8.13 .97\end{array}$ & $\mathrm{R}$ & I & $\begin{array}{l}\text { Exemption from income tax on interest, commission and issuance } \\
\text { expenditures of debt securities with a minimum average maturity of } 96 \\
\text { months. Exemption from income tax on interest of loans with a minimum } \\
\text { maturity of fifteen years. }\end{array}$ \\
\hline
\end{tabular}


Foreign portfolio investment and external loans (continued)

\begin{tabular}{|c|c|c|c|}
\hline Normative & Date & $N^{(1)} D^{(2)}$ & Description \\
\hline Directive MF 85 & 4.24 .97 & L I & $\begin{array}{l}\text { Reduction in the financial transaction tax (IOF) from } 7 \% \text { to } 2 \% \text { on foreigr } \\
\text { investment in fixed-income funds, from the differentiated rates to a flat } \\
\text { rate of } 0 \% \text { on loans, and from } 7 \% \text { to } 2 \% \text { on interbank exchange } \\
\text { operations between financial institutions abroad and institutions } \\
\text { authorized to operate in the exchange market, and on the formation of } \\
\text { short-term cash holdings of nonresidents. }\end{array}$ \\
\hline Resolution 2,384 & 5.22 .97 & L I & $\begin{array}{l}\text { Permission for foreign capital, registered under Annexes I to IV, to invest } \\
\text { in convertible debentures, and futures and options markets as hedge } \\
\text { operations. }\end{array}$ \\
\hline Resolution 2,406 & 6.26 .97 & L I & $\begin{array}{l}\text { Authorization for creation of Investment Funds in Emerging Firms - } \\
\text { Foreign Capital. }\end{array}$ \\
\hline Circular 2,783 & 11.13 .97 & L I & $\begin{array}{l}\text { Reduction in the minimum average maturity required for loans from } 36 \text { t } \\
\text { twelve months for new loans, and to six months for renewed or extended } \\
\text { loans. }\end{array}$ \\
\hline Circular 2,807 & 2.26 .98 & R I & $\begin{array}{l}\text { Increase in the minimum average maturity required for loans from twelve } \\
\text { to } 24 \text { months for new loans, and from six to twelve months for renewed c } \\
\text { extended loans (revoked Circulars } 2,661 \text { and replaced Circular } 2,783 \text { ). }\end{array}$ \\
\hline $\begin{array}{l}\text { Circular } 2,834 \text {, replaced by } \\
\text { Circular } 2,850\end{array}$ & $\begin{array}{l}\text { 8.24.98, } \\
11.30 .98\end{array}$ & L I & $\begin{array}{l}\text { Reduction in the minimum average maturity required for loans from } 24 \text { t } \\
\text { twelve months for new loans, and from twelve to six months for renewed } \\
\text { or extended loans (revoked Circular } 2,807 \text { ). }\end{array}$ \\
\hline Directive MF 348 & 12.30 .98 & R I & $\begin{array}{l}\text { Increase in the financial transaction tax (IOF) from } 2 \% \text { to } 2.38 \% \text { on } \\
\text { foreign investment in fixed-income funds, on interbank exchange } \\
\text { operations between financial institutions abroad and institutions } \\
\text { authorized to operate in the exchange market, and on the formation of } \\
\text { short-term cash holdings of nonresidents, and from } 0 \% \text { to } 0.38 \% \text { on } \\
\text { foreign investment in securities. Imposition of a } 0.38 \% \text { rate on financial } \\
\text { transfers abroad and from abroad. }\end{array}$ \\
\hline
\end{tabular}

Circular 2,859

Resolution 2,590

Resolution 2,591

Directives MF 56 and $157 \quad 3.12 .99$,

Resolution 2,625

Resolution 2,622

Directive MF 306
6.24 .99

1.27 .99

1.28 .99

1.28 .99

7.29 .99

7.29 .99

8.18.99

L I Reduction in the minimum average maturity required for loans from twelve to nine months for new loans, and from nine to six months for renewed or extended loans (revoked Circular 2,850).

L I Reduction in the minimum average maturity from 180 to 90 days for agricultural loans.

L I Permission for foreign capital, registered under Annexes I to IV, to invest in public debt securities of the federal government.

L I Reduction in the financial transaction tax (IOF) from $2.38 \%$ to $0.5 \%$ on foreign investment in fixed-income funds, on interbank exchange operations between financial institutions abroad and institutions authorized to operate in the exchange market, and on the formation of short-term cash holdings of nonresidents.

L Permission for financial institutions to issue bonds abroad and use the proceeds freely in the domestic market as long as those resources stay a minimum of five years in the country.

I Permission for nonresidents to invest in futures contracts related to agricultural products.

I Reduction in the financial transaction tax (IOF) from 0.5 to $0 \%$ on foreign investment in fixed-income funds, on interbank exchange operations between financial institutions abroad and institutions authorized to operate in the exchange market, and on the formation of short-term cash holdings of nonresidents (revoked Directives MF 56 and 157). 
Foreign portfolio investment and external loans (continued)

\begin{tabular}{|c|c|c|c|c|}
\hline Normative & Date & $\mathrm{N}^{(1}$ & $D^{(2)}$ & Description \\
\hline Directive MF 306 & 8.18 .99 & $\mathrm{~L}$ & I & $\begin{array}{l}\text { Reduction in the financial transaction tax (IOF) from } 0.5 \text { to } 0 \% \text { on foreign } \\
\text { investment in fixed-income funds, on interbank exchange operations } \\
\text { between financial institutions abroad and institutions authorized to operate } \\
\text { in the exchange market, and on the formation of short-term cash holdings } \\
\text { of nonresidents (revoked Directives MF } 56 \text { and 157). }\end{array}$ \\
\hline Resolution 2,628 & 8.6 .99 & $\mathrm{~L}$ & I & $\begin{array}{l}\text { Permission for foreign capital, registered under Annexes I to IV, to invest } \\
\text { in fixed-income instruments, although within some limits (replaced } \\
\text { Resolutions 2,384 and 2,591). }\end{array}$ \\
\hline Resolution 2,683 & 12.29 .99 & $\mathrm{~L}$ & I & $\begin{array}{l}\text { Elimination of the requirement of five years for the proceeds from the } \\
\text { bonds issued abroad by financial institutions to stay in the country. } \\
\text { Elimination of minimum average maturity required for external loans } \\
\text { (revoked Resolution } 2,625 \text { ). }\end{array}$ \\
\hline Directive MF 492 & 12.29 .99 & $\mathrm{R}$ & I & $\begin{array}{l}\text { Determination of the financial transaction tax (IOF) on external loans at a } \\
\text { rate of } 0 \% \text { for those with average maturity above } 90 \text { days, and } 5 \% \text { for } \\
\text { those with average maturity up to } 90 \text { days. }\end{array}$ \\
\hline $\begin{array}{l}\text { Provisory Measure 2,013- } \\
4 \text {, turned into Law 9,959 }\end{array}$ & $\begin{array}{l}12.30 .99 \\
1.27 .00\end{array}$ & $\mathrm{R}$ & $\mathrm{O}$ & $\begin{array}{l}\text { Termination of the income tax exemption on interest, commission and } \\
\text { issuance expenses for debt securities with a minimum average maturity of } \\
96 \text { months, and of the income tax exemption for loans with maturity } \\
\text { greater than } 15 \text { years. Interest payments on all external loans and debt } \\
\text { securities, regardless of the maturity, taxed at } 15 \% \text {. }\end{array}$ \\
\hline Resolution 2,689 & 1.26 .00 & $\mathrm{~L}$ & I & $\begin{array}{l}\text { Regulation of investment in the financial and capital markets, allowing } \\
\text { nonresidents to invest in the same instruments as residents. Inward } \\
\text { investment must be registered at the Central Bank. }\end{array}$ \\
\hline Circular 2,975 & 3.29 .00 & $E$ & & $\begin{array}{l}\text { Update on conditions for the electronic registration (RDE) of portfolio } \\
\text { investment (replaced Circular 2,728). }\end{array}$ \\
\hline Resolution 2,770 & 8.30 .00 & $\mathrm{~L}$ & I & $\begin{array}{l}\text { Consolidation of the regulation on external loans, including debt } \\
\text { securities. Termination of the requirement of prior approval by the Central } \\
\text { Bank for those operations, except for those involving the public sector as } \\
\text { a debtor. Maintenance of the requirement of registration at the Central } \\
\text { Bank for those operations (revoked } 67 \text { resolutions, } 96 \text { circulars, and } 51 \\
\text { circular letters, including Resolutions } 63,64,125 \text {, and } 1,986 \text {, and Circular } \\
2,410 \text { ). }\end{array}$ \\
\hline Circular 3,027 & 2.22 .01 & $E$ & & $\begin{array}{l}\text { Introduction of electronic registration (RDE) for external loans, including } \\
\text { debt securities. }\end{array}$ \\
\hline $\begin{array}{l}\text { Constitutional } \\
\text { Amendment } 37 \text {, and } \\
\text { Decree } 4,296\end{array}$ & $\begin{array}{l}6.12 .02 \\
7.10 .02\end{array}$ & $\mathrm{~L}$ & I & $\begin{array}{l}\text { Exemption from the Provisional Contribution on Financial Transactions } \\
\text { (CPMF) for entries into foreign investor accounts involving inflows of } \\
\text { financial resources to the country and remittances abroad when such } \\
\text { resources are used exclusively in stock operations. }\end{array}$ \\
\hline Resolution 3,217 & 6.30 .04 & $\mathrm{~L}$ & $\mathrm{O}$ & Permission for the prepayment of external debt, including debt securities. \\
\hline Resolution 3,221 & 7.29 .04 & $\mathrm{~L}$ & I & $\begin{array}{l}\text { Establishment of conditions for the issuance of real-denominated external } \\
\text { debt. }\end{array}$ \\
\hline
\end{tabular}

(1) $L, R$ and $E$ refer to liberazing, restrictive and regulatory measures, respectively.

(2) I and $O$ refer to related to measures to inflows and outflows, respectively. 


\begin{tabular}{|c|c|c|c|c|}
\hline Normative & Date & \multicolumn{2}{|c|}{$N^{(1)} D^{(2)}$} & Description \\
\hline \multicolumn{5}{|c|}{$\begin{array}{l}\text { Regulation implemented } \\
\text { prior to the } 1990 \text { s }\end{array}$} \\
\hline Circular 1,280 & 1.18 .88 & & & $\begin{array}{l}\text { Requirement that Brazilian investments abroad be compensated by a sale } \\
\text { to the Central Bank of gold bought in the domestic market for a value } \\
\text { equivalent to the investment. Previously, authorization for Brazilian } \\
\text { investment abroad was decided on a case-by-case basis by the monetary } \\
\text { authority. }\end{array}$ \\
\hline Resolution 1,534 & 11.30 .88 & & & $\begin{array}{l}\text { As an alternative to the exchange compensation with gold mechanism, } \\
\text { investment abroad by Brazilian enterprises may be authorized at the } \\
\text { official exchange rate in an amount equal to direct foreign investment } \\
\text { received by the firm. }\end{array}$ \\
\hline \multicolumn{5}{|l|}{ Main changes } \\
\hline Resolution 1,925 & 5.5 .92 & $\mathrm{~L}$ & O & $\begin{array}{l}\text { Termination of the mechanism of exchange compensation with gold, } \\
\text { transferring the operations of investment abroad to the floating exchange } \\
\text { rate market. }\end{array}$ \\
\hline Circular 2,243 & 10.14 .92 & $\mathrm{~L}$ & O & $\begin{array}{l}\text { Authorization for nonfinancial resident firms to invest abroad up to US } \$ 1 \\
\text { million without prior authorization, for each } 12 \text { months by economic } \\
\text { group. When above this value, investors must provide information to the } \\
\text { Central Bank } 30 \text { days ahead of the exchange transaction. }\end{array}$ \\
\hline Circular 2,472 & 8.31 .94 & $\mathrm{~L}$ & 0 & $\begin{array}{l}\text { Increase in the limit of the value of Brazilian investments abroad that do } \\
\text { not require previous authorization from US } \$ 1 \text { to US } \$ 5 \text { million. }\end{array}$ \\
\hline Resolution 2,111 & 9.22 .94 & $\mathrm{~L}$ & 0 & $\begin{array}{l}\text { Authorization of Foreign Investment Funds (FIEX) for investment in debt } \\
\text { securities in international markets. }\end{array}$ \\
\hline Resolution 2,318 & 9.26 .96 & $\mathrm{~L}$ & $\mathrm{OH}$ & $\begin{array}{l}\text { Regulation of residents' investments in Brazilian Depositary Receipts } \\
\text { (BDRs). }\end{array}$ \\
\hline Resolution 2,356 & 2.27 .97 & $\mathrm{~L}$ & 0 & $\begin{array}{l}\text { Permission for residents to invest in Depositary Receipts issued abroad } \\
\text { representing resident firms' securities. }\end{array}$ \\
\hline Circular 2,863 & 2.10 .99 & $\mathrm{R}$ & 0 & $\begin{array}{l}\text { Increase in the minimum share of Brazilian sovereign bonds in FIEX funds } \\
\text { from } 60 \% \text { to } 80 \% \text {. }\end{array}$ \\
\hline Circular 2,877 & 3.17 .99 & $\mathrm{R}$ & 0 & $\begin{array}{l}\text { Prohibition of financial institutions to invest directly or indirectly in FIEX } \\
\text { funds. }\end{array}$ \\
\hline Resolution 2,716 & 4.12 .00 & $\mathrm{~L}$ & O & $\begin{array}{l}\text { Permission for private pension funds to invest up to } 10 \% \text { of their } \\
\text { resources in BDRs. }\end{array}$ \\
\hline Resolution 2,717 & 4.12 .00 & $\mathrm{~L}$ & 0 & $\begin{array}{l}\text { Permission for insurance companies, capitalization companies, and open } \\
\text { private pension funds to invest up to } 10 \% \text { of their resources in BDRs. }\end{array}$ \\
\hline Resolution 2,763 & 8.9 .00 & $\mathrm{E}$ & & $\begin{array}{l}\text { New regulation on residents' investments in Brazilian Depositary Receipts } \\
\text { (BDRs), which represent securities of nonresident companies (replaced } \\
\text { Resolution 2,318). }\end{array}$ \\
\hline $\begin{array}{l}\text { Decree-Law } 1,060 \\
\text { Circular } 3,039 \text { and } \\
\text { Resolution } 2,911\end{array}$ & $\begin{array}{l}10.21 .69 \\
6.8 .01 \\
11.29 .01\end{array}$ & $\mathrm{E}$ & & $\begin{array}{l}\text { Implementation of the first survey of Brazilian capital abroad, which has } \\
\text { subsequently been conducted on an annual basis. The provision of } \\
\text { information from residents on their assets abroad is mandatory. }\end{array}$ \\
\hline
\end{tabular}

(1) $L, R$ and $E$ refer to liberazing, restrictive and regulatory measures, respectively.

(2) I and $O$ refer to related to measures to inflows and outflows, respectively. 


\section{Appendix C: Classification of capital flows}

In the text, we classify the items of the capital and financial account into six groups: net direct investment, portfolio investment, loans and trade credits, other shortterm assets, official-agency-related loans, and other items. ${ }^{43}$ We do not use the category "other investments" of IMF's classification because it consists of disparate flows. In particular, it includes both compensatory flows and private bank loans; thus, using the balance of this category may be misleading. For example, in 2002, despite negative net loan flows and large currency transfers abroad, the other investments balance does not appear as significantly negative (only US\$ -0.2 billion) because of IMF loans (a net inflow of US\$ 11.5 billion).

a) Net direct investment. It follows IMF's definition. It covers inflows (outflows) related to acquisition, subscription and increase in the capital of resident (nonresident) enterprises, and similarly flows related to partial or total sale of the capital. It also includes intercompany loans. ${ }^{44}$ Differently from the investor in equities, the "direct investor seeks a significant voice in the management" of the enterprise (IMF, 1993, p.80). In general, the criterion used is that the direct investor owns $10 \%$ or more of the ordinary shares or voting power (for an incorporated enterprise) or the equivalent (for an unincorporated enterprise) (IMF, 1993, p.86);

b) Portfolio investment. This category follows IMF's definition as well. It is represented by cross-border investment in equity securities that is not classified as direct investment, and debt securities. ${ }^{45}$ We also consider these two items separately when relevant. This category includes securities negotiated in Brazil and abroad;

\footnotetext{
${ }^{43}$ The balance of payments statistics are produced by the Central Bank of Brazil and are available on its website (www.bcb.gov.br). The statistics follow IMF's recommendations (IMF, 1993; Banco Central do Brasil, 2001). Although those recommendations were implemented in 2001, the historical statistics were conformed to the new methodology. We do not use the statistics published in the International Financial Statistics (IFS) database of the IMF, because its high level of aggregation does not allow us to make the classification used in this paper.

${ }^{44}$ It should include reinvested earnings as well, but because the data does not include this item since 1999, we exclude it to maintain the coherence throughout the series. The statistics do not include intercompany trade credits either.

${ }^{45}$ Throughout the paper, we have excluded from the series of portfolio investment and loans the values related to the conversion of debt under the Brady Plan, which appear in the second quarter of 1994. Maintaining them in the series would distort the analysis.
} 
c) Loans and trade credits. It comprises loans not related to official agencieswhich we call loans—and suppliers' and buyers' credits;

d) Other short-term assets. This group aims to capture the movements of currency and deposits, which played an important role during the crises. For example, in 1998, the negative balance of this category reached US\$ -17.6 billion. It consists of three items of the balance of payments statistics: "currency and deposits of nonresidents" (which includes flows through the called CC5 accounts classified as "disposable funds"), "currency and deposits of non-financial residents" (which includes deposits available abroad), and "other short-term assets" within other domestic investments (which includes flows through the CC5 accounts below 10,000 reais);

e) Official-agency-related loans. It consists of loans to the monetary authority (such as those from the IMF, BIS, Bank of Japan, and U.S. Treasury) and long-term financing from bilateral or multilateral organizations (such as IBD and World Bank Group). ${ }^{46}$ These loans have clearly worked as compensatory flows. For instance, in the crisis years of 1998 and 2002, the balance of this group was largely positive, US\$ 10.9 and US\$ 12.2 billion, respectively;

f) Other items. This category corresponds to the remaining items of the capital and financial account. It includes diverse items, but quantitatively the most important ones are "currency and deposits of financial residents" 47 and "other liabilities" within other foreign investments (mainly external liabilities assumed by the Central Bank, but whose repayments and interests were not sent abroad duly). ${ }^{48}$ The latter was the major item of the group through mid-1990s because of the arrears that occurred in some periods.

\footnotetext{
${ }^{46}$ Before 1979, some of the items that comprise official-agency-related loans are available only on an annual basis. We distributed the annual values over the four quarters and added to the data available quarterly.

${ }^{47}$ We do not classify "currency and deposits of financial residents" into the group "other short-term assets" because they are the main counterpart of the payments registered in the balance of payments. For example, when a resident repays a loan, it represents a reduction in external liabilities (increase in net assets of residents), but as counterpart there is a reduction in the foreign assets of the bank that sold the foreign currency (reduction in net assets of residents). In fact, the balance of this item was positive in 1998 and 2002.

48 The other items are "capital account" (according to IMF's (1993) definition, which covers capital transfers and acquisition or disposal of nonproduced, nonfinancial assets), financial derivatives, and other long-term assets of residents (Brazil's participation in multilateral organizations, and greater-than-oneyear escrow deposits).
} 
We also classify flows according to their maturity. Short-term debt flows correspond to equities and short-term debt securities, loans and trade credits. When including other short-term assets, we call them "short-term flows expanded". Long-term debt flows in turn comprise long-term debt securities, loans and trade credits, which, according to the balance of payments classification, correspond to contracts with maturity superior to 360 days. When including net direct investment, we call this group "long-term flows expanded".

\section{Appendix D: Methodology used in the VAR estimation}

To estimate the VAR, we have used the following endogenous variables: ${ }^{49}$ i) log-level of industrial production in Brazil (seasonally adjusted); ii) current account balance at constant prices (seasonally adjusted by the authors; ratio to the average GDP in the period); ${ }^{50}$ iii) private capital account (ratio to the average GDP in the period); iv) $\log$ of terms of trade, measured as the ratio of export prices to import prices; v) EMBI+ Brazil, sovereign spread; ${ }^{51}$ vi) log of real effective exchange rate (measured as the value of foreign currency in terms of domestic currency); ${ }^{52}$ and vii) real interest rate, measured as the Selic interest rate deflated by the IPCA. ${ }^{53}$ The exogenous variables are the Fed Funds interest rate and the U.S. industrial production (seasonally adjusted).

The sample goes from 1995:1 through 2004:8. It starts when the balance of payments statistics on a monthly basis are available according to IMF's (1993)

\footnotetext{
${ }^{49}$ The data source are the following: i) IBGE; ii) and iii) BCB; iv) Funcex, available in Ipeadata; v) JP Morgan; vi) and vii) BCB. The estimations were conducted using basically the Rats software.

${ }^{50}$ We do not use the ratio to the current GDP because the large movements in the exchange ratio tend to distort the analysis: movements in the ratio can reflect changes in the exchange ratio rather than capital account changes. On the other hand, the absence of normalization generated problems for the convergence of the algorithm to estimate the structural parameters. The same reasoning is valid for the private capital account.

51 Average of daily data of the EMBI Brazil from 1992:1 through 1996:12, and the EMBI+ Brazil thereafter.

${ }^{52}$ Estimated by the Central Bank of Brazil using the IPCA as internal deflator, and U.S. CPI as external deflator. It corresponds to the average of the domestic currency value in relation to 15 countries weighed by the participation of these countries in Brazil's exports.

${ }^{53}$ We use the inflation accumulated in the last twelve months because of the difficulties in using a measure for expected inflation for the whole sample. We use 12 months because of the volatility of the inflation rate of one or even six months. From 1995:01 through 1995:07, however, we use the average inflation in the period starting in 1994:09 instead of 12 months to avoid the distortions caused by the high-inflation period.
} 
methodology. Furthermore, it does not include the high-inflation period. ${ }^{54}$ We have estimated the VAR using the variables in levels, ${ }^{55}$ employing six lags for the endogenous variables. ${ }^{56}$ For the exogenous variables, we use their contemporaneous and one-period lagged values. ${ }^{57}$

To determine the identification structure concerning the contemporaneous effects of the shocks, we have considered the relationships between variables and possible lags in the effects of one variable on another as well as the correlation of the estimated reduced-form residuals. First, we have assumed that current account, terms of trade and interest rate are not affected contemporaneously by shocks to other variables. Effective exports and imports are usually result of contracts set in advance. ${ }^{58}$ Terms of trade, besides depending on exogenous variables, are affected by pricing-to-market decisions, which tend to react with some lag. Although interest rate is a financial variable, we are using the rate whose target is set by the Central Bank. We are assuming that there is a one-month lag in the reaction of the Central Bank either because information is not available promptly or because there is some lag in Central Bank's decisions. In particular, the target for the basic interest rate is usually set on a monthly basis rather than on a daily basis. ${ }^{59}$ Second, since the EMBI and exchange rate are financial variables, they tend to react more quickly. We assume then that reduced-form shocks to the other variables affect those variables contemporaneously. Third, for output and capital flows, we have used the matrix of correlation coefficients of reduced-form residuals. We have considered only residuals that have a correlation coefficient greater than 0.1 , which led to assume that output responds contemporaneously to terms of trade, EMBI, exchange rate, ${ }^{60}$ and interest rate, and capital flows to EMBI, exchange rate and interest rate.

\footnotetext{
${ }^{54}$ Thus, we do not face the problem of measuring the real interest rate in the high-inflation period and making it comparable to the low-inflation period.

55 The estimation is consistent even in the presence of variables integrated of order one (Sims, Stock, and Watson, 1990; Hamilton, 1994).

${ }^{56}$ Schwarz criterion has indicated two lags, but, using a Lagrange multiplier test, we reject the null hypothesis of absence of serial correlation in the residuals. We then add lags until accepting the null of no serial correlation.

57 Further lags were not significant. The presence of one lag also avoids the problem of spurious regression (Hamilton, 1994).

${ }^{58}$ Even in the case of terms of trade, the correlation coefficient between the reduced-form shock to that variable and to current account balance was not positive $(-0.02)$.

${ }^{59}$ Even in the case of crises, the basic interest rate did not react in the same month.

${ }^{60}$ The correlation with exchange rate is low, but the coefficient was included to ease the convergence of the algorithm.
} 
The resulting structure was the following (time subscripts were omitted):

$$
\left[\begin{array}{ccccccc}
1 & 0 & 0 & a_{14} & a_{15} & a_{16} & a_{17} \\
0 & 1 & 0 & 0 & 0 & 0 & 0 \\
0 & 0 & 1 & 0 & a_{35} & a_{36} & a_{37} \\
0 & 0 & 0 & 1 & 0 & 0 & 0 \\
a_{51} & a_{52} & a_{53} & a_{54} & 1 & a_{56} & a_{57} \\
a_{61} & a_{62} & a_{63} & a_{64} & a_{65} & 1 & a_{67} \\
0 & 0 & 0 & 0 & 0 & 0 & 1
\end{array}\right]\left[\begin{array}{c}
\text { OUT } \\
C A \\
K A \\
T O T \\
E M B I \\
E R \\
I N T
\end{array}\right]=c+A(L)\left[\begin{array}{c}
\text { OUT } \\
C A \\
K A \\
T O T \\
E M B I \\
E R \\
I N T
\end{array}\right]+H(L)\left[\begin{array}{c}
e_{O U T} \\
e_{C A} \\
I N T_{-} U S
\end{array}\right]+\left[\begin{array}{c}
e_{K A} \\
e_{T O T} \\
e_{E M B I} \\
e_{E R} \\
e_{I N T}
\end{array}\right],
$$

where OUT, CA, KA, TOT, EMBI, ER, INT, OUT_US, and INT_US stand for output, current account, private capital account, terms of trade, EMBI+ Brazil, real effective exchange rate, real interest rate, U.S. output, and U.S. interest rate, respectively, $\mathrm{c}$ is a vector of constants, $\mathrm{A}$ and $\mathrm{H}$ are coefficient matrices, $\mathrm{L}$ is the lag operator, and $e$ is the structural shock. Since there are 26 free parameters, the model is over-identified. Even though most of the structural coefficients are not significant, we can accept the identification restrictions ( $\mathrm{p}$-value of 0.293 ). 
Current Account and Private Capital Account

(four-quarter cumulative balance - 1970:4-2004:2 - at 2003 prices)

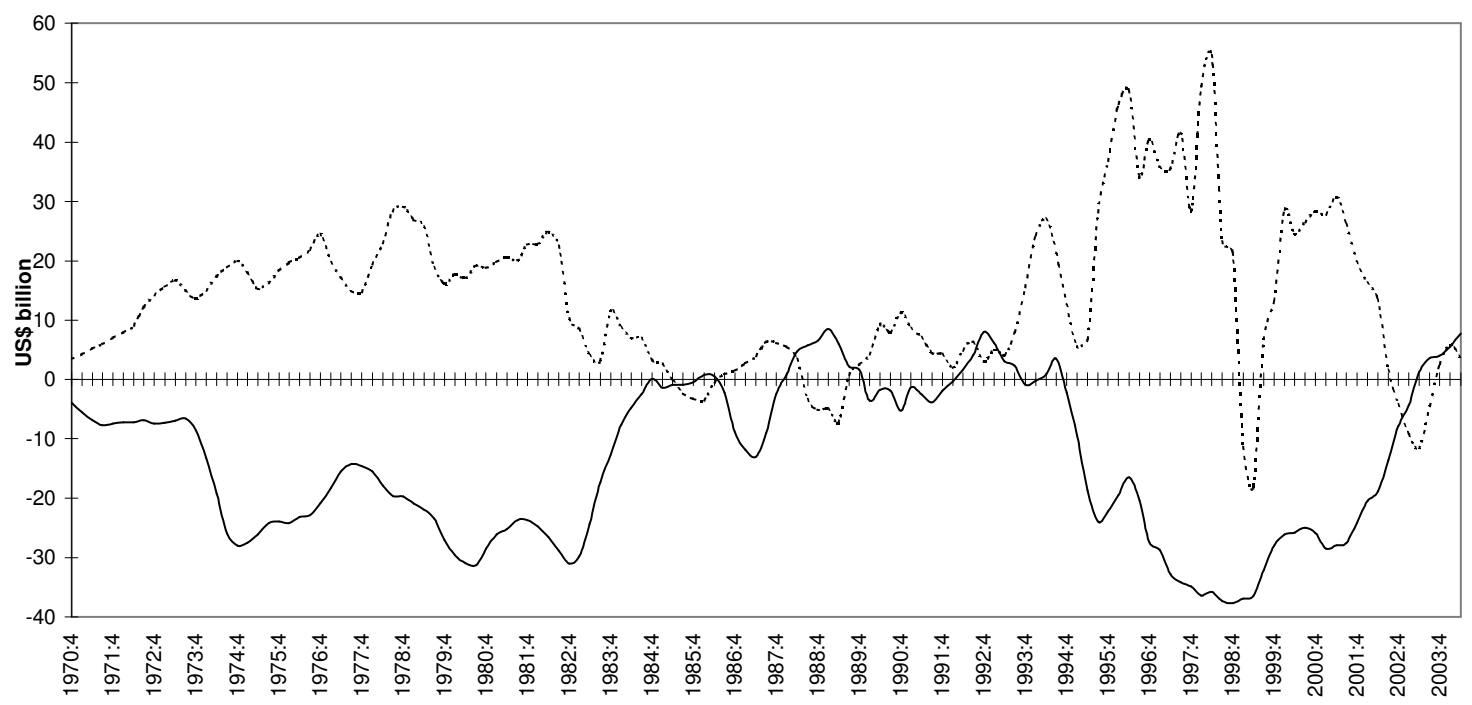

Trade Balance and Income Balance

(four-quarter cumulative balance - 1970:4-2004:2 - at 2003 prices)

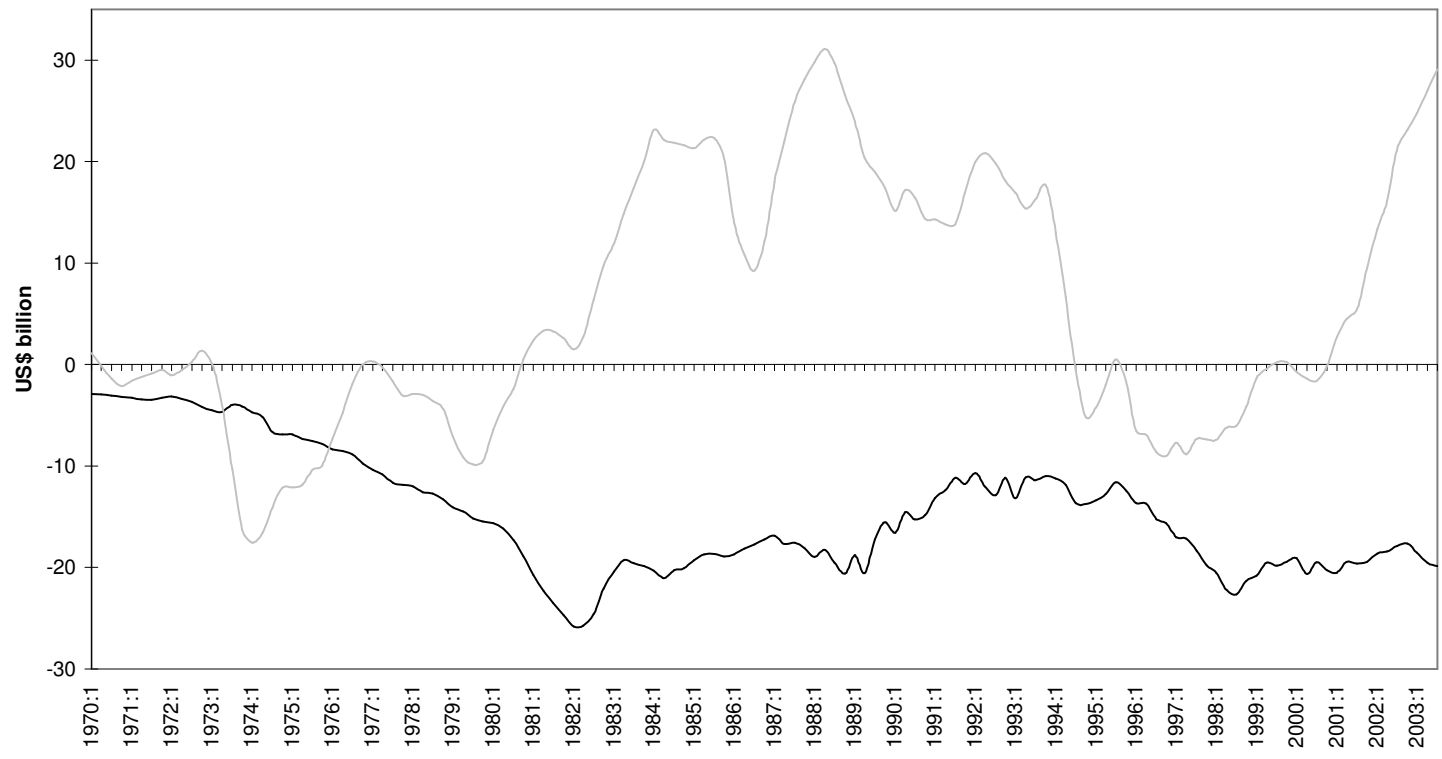

_Income Balance _ Trade Balance 
Figure 3

Real Effective Exchange Rate and Cumulative 12-month Trade Balance

(1991:1-2004:9)

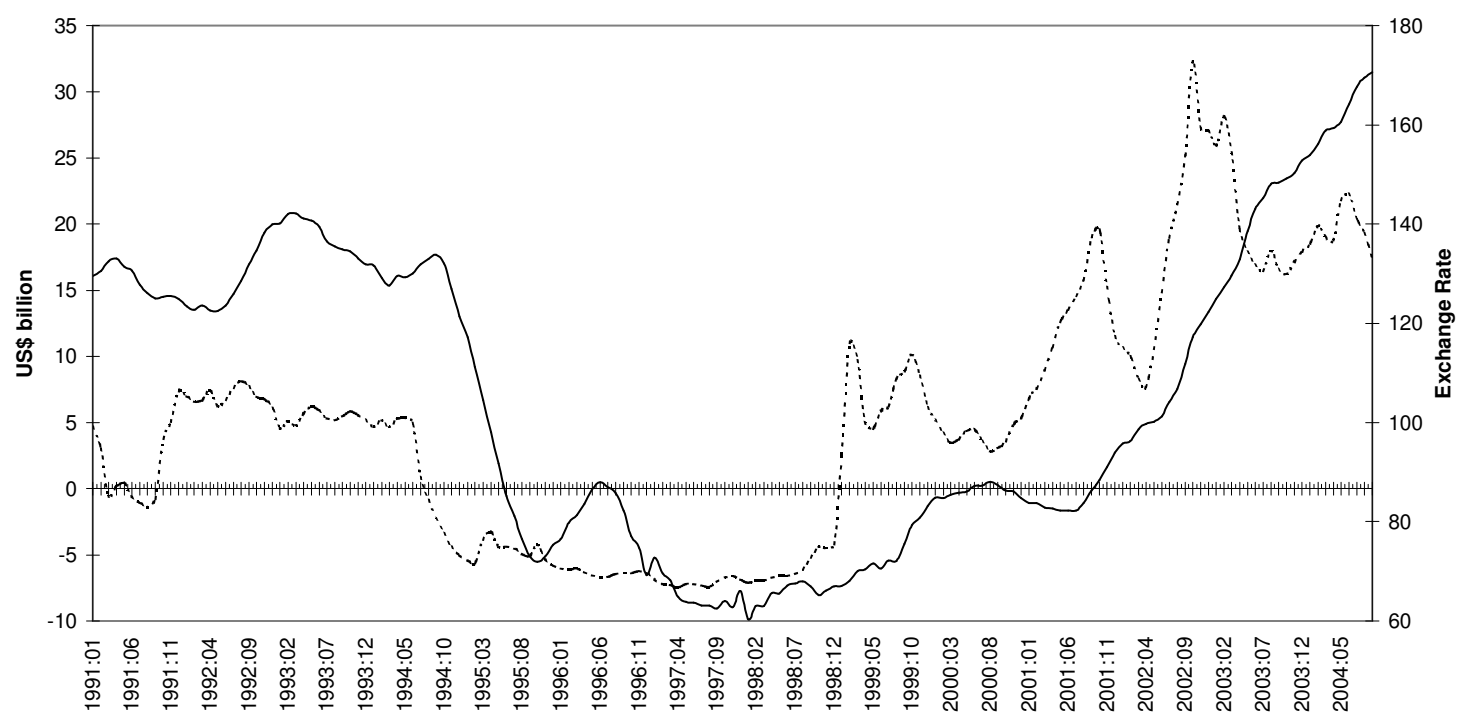

Trade Balance -... - - Real Effective Exchange Rate

Figure 4

GDP Growth Rate (1991-2004)

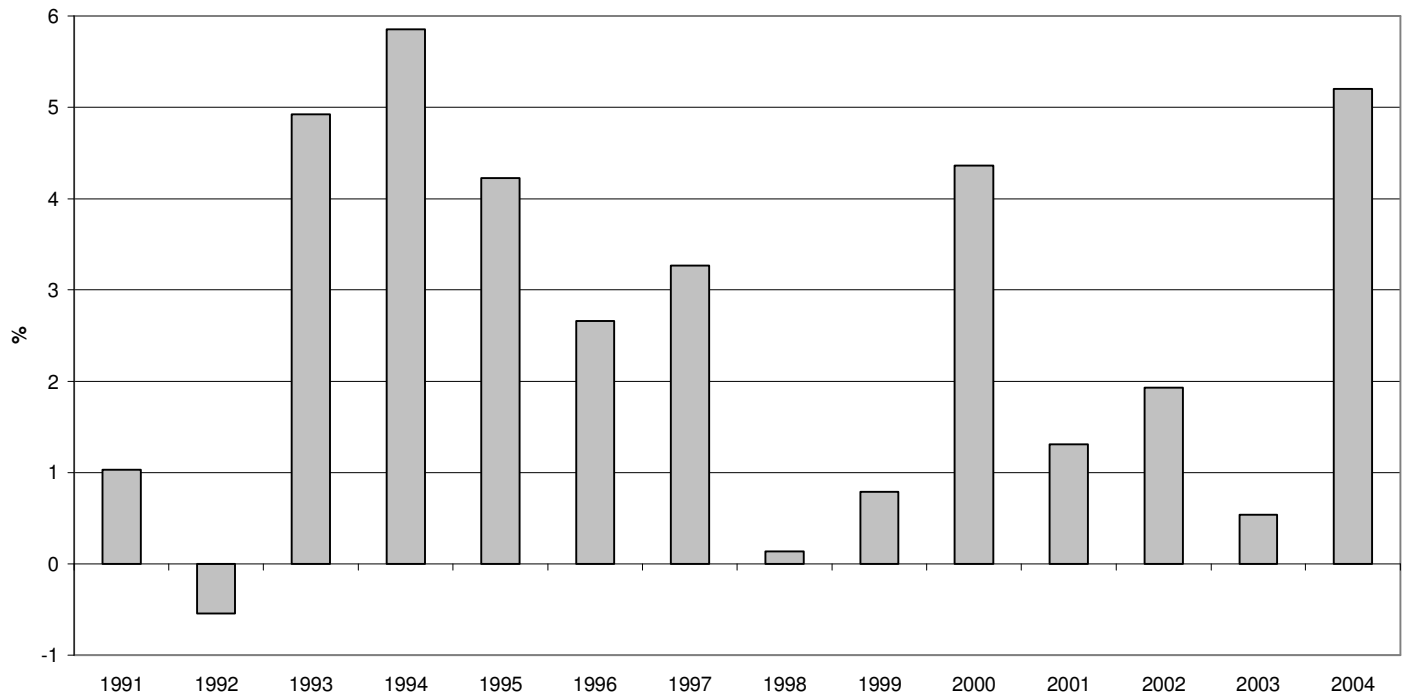


Figure 5

Nominal Exchange Rate

(1990:1-2004:10)

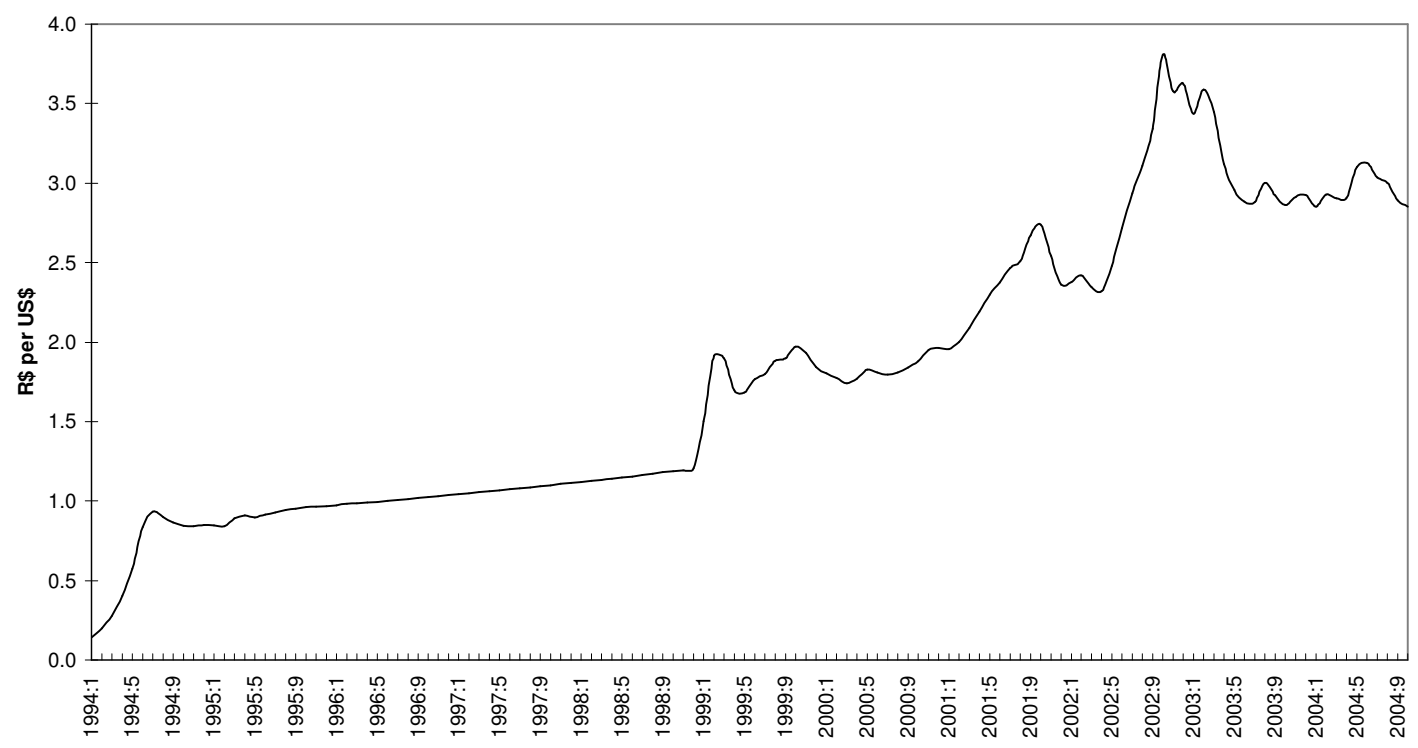

Figure 6

Ratio of Exports plus Imports to GDP (1970-2004)

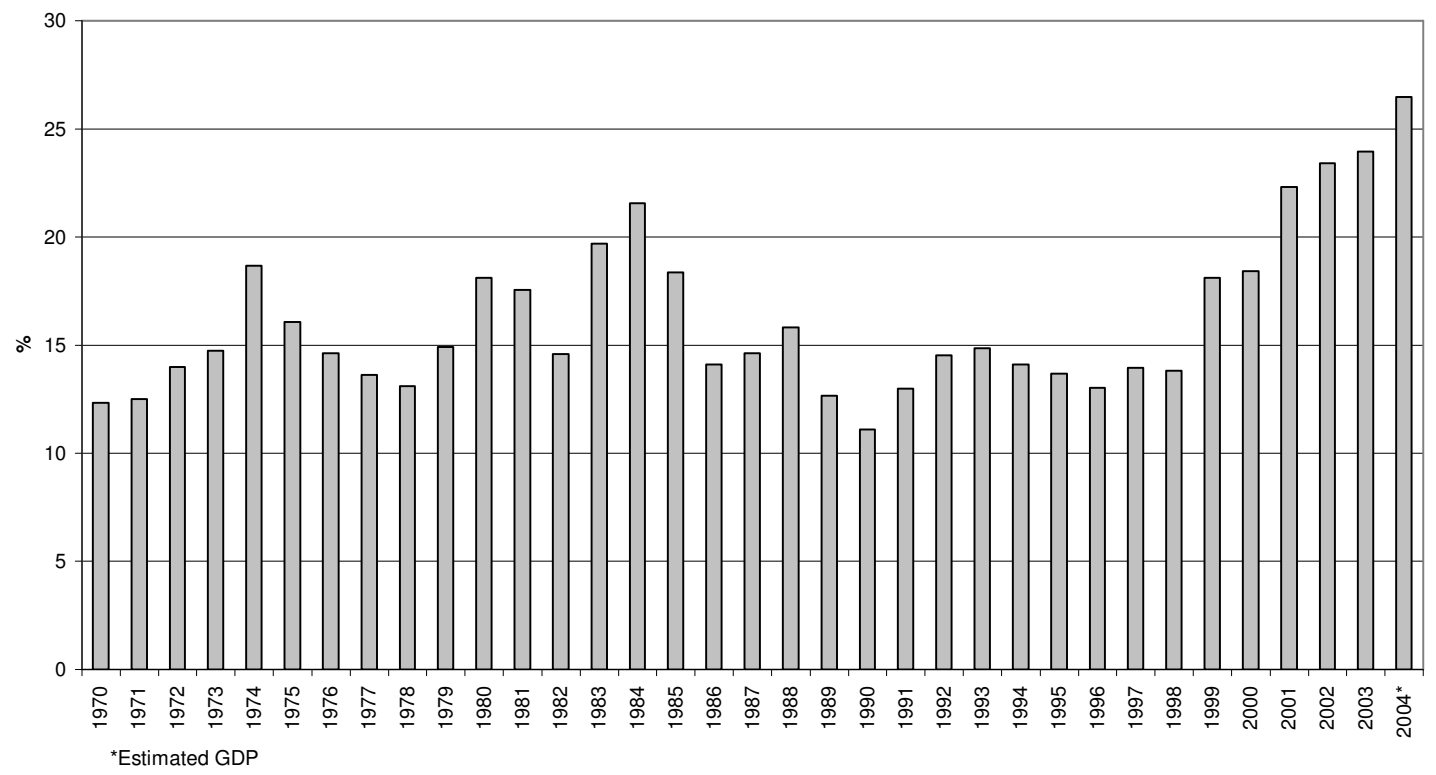


Figure 7

Income Account Deficit

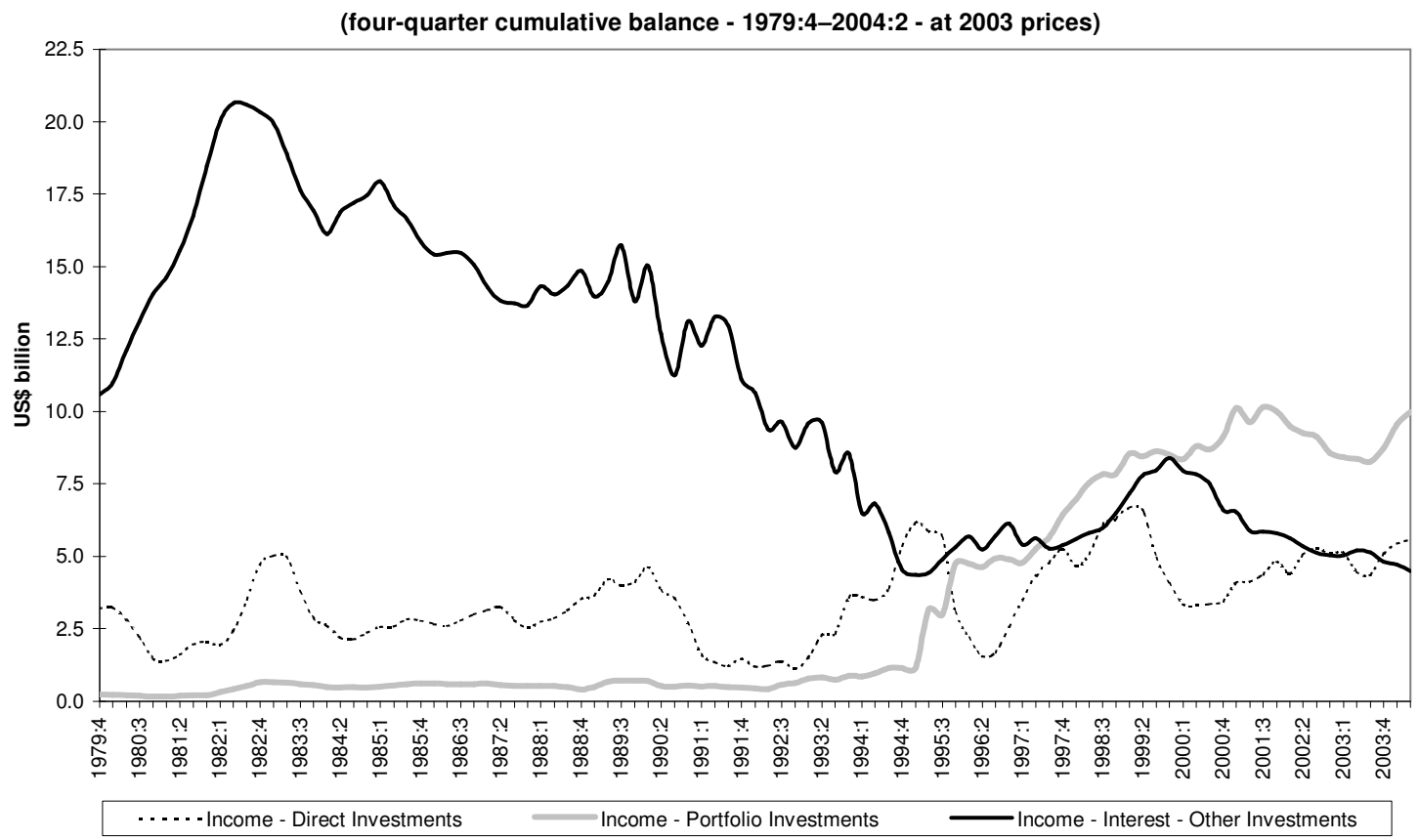

Figure 8

Direct Investments, Portfolio Investments, Loans and Trade Credits and Other Short-Term Assets (four-quarter cumulative balance- 1990:4 - 2004:2 - at 2003 prices)

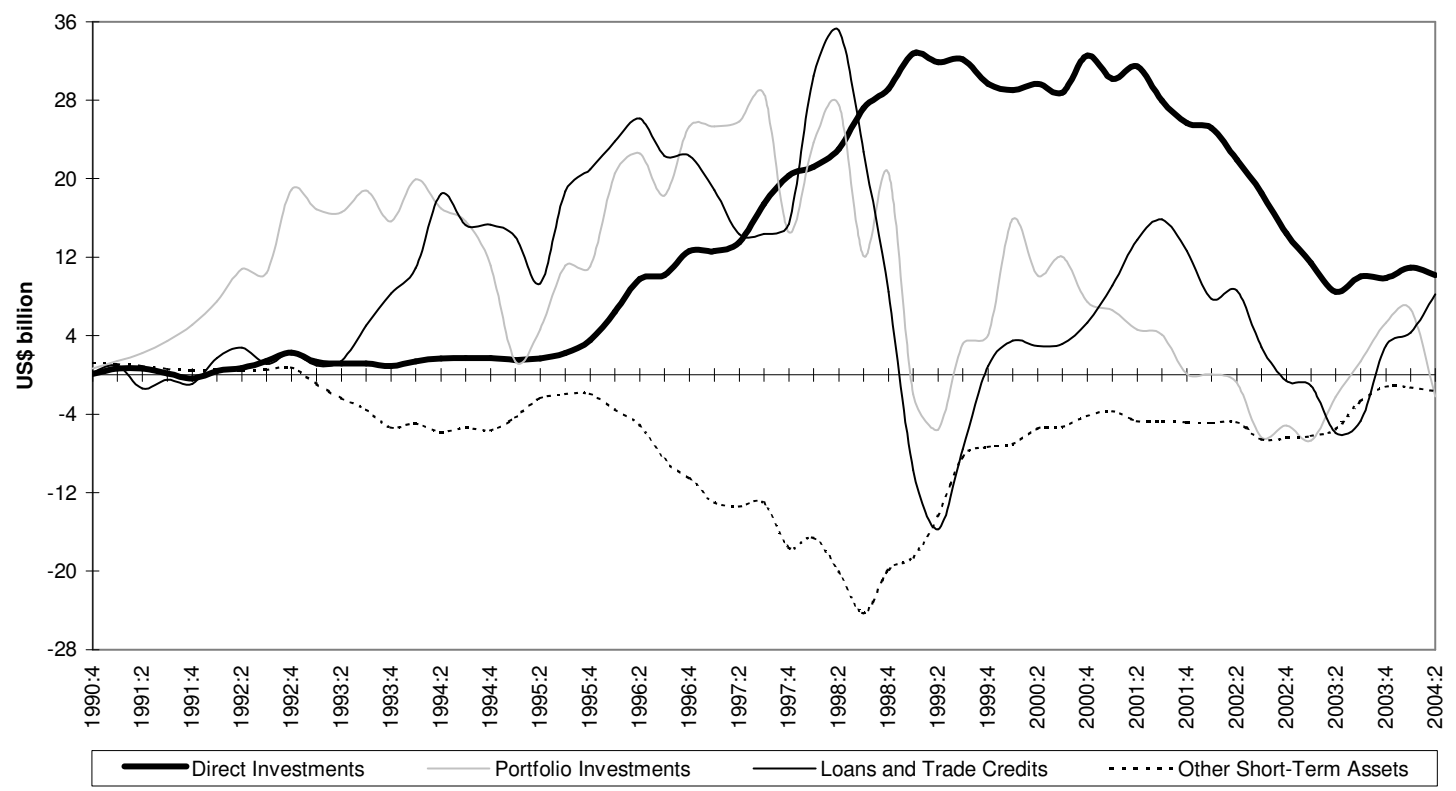


Figure 9

Debt Securities, Loans, Trade Credits and Equity Securities - Ratio to GDP (1970-2003)

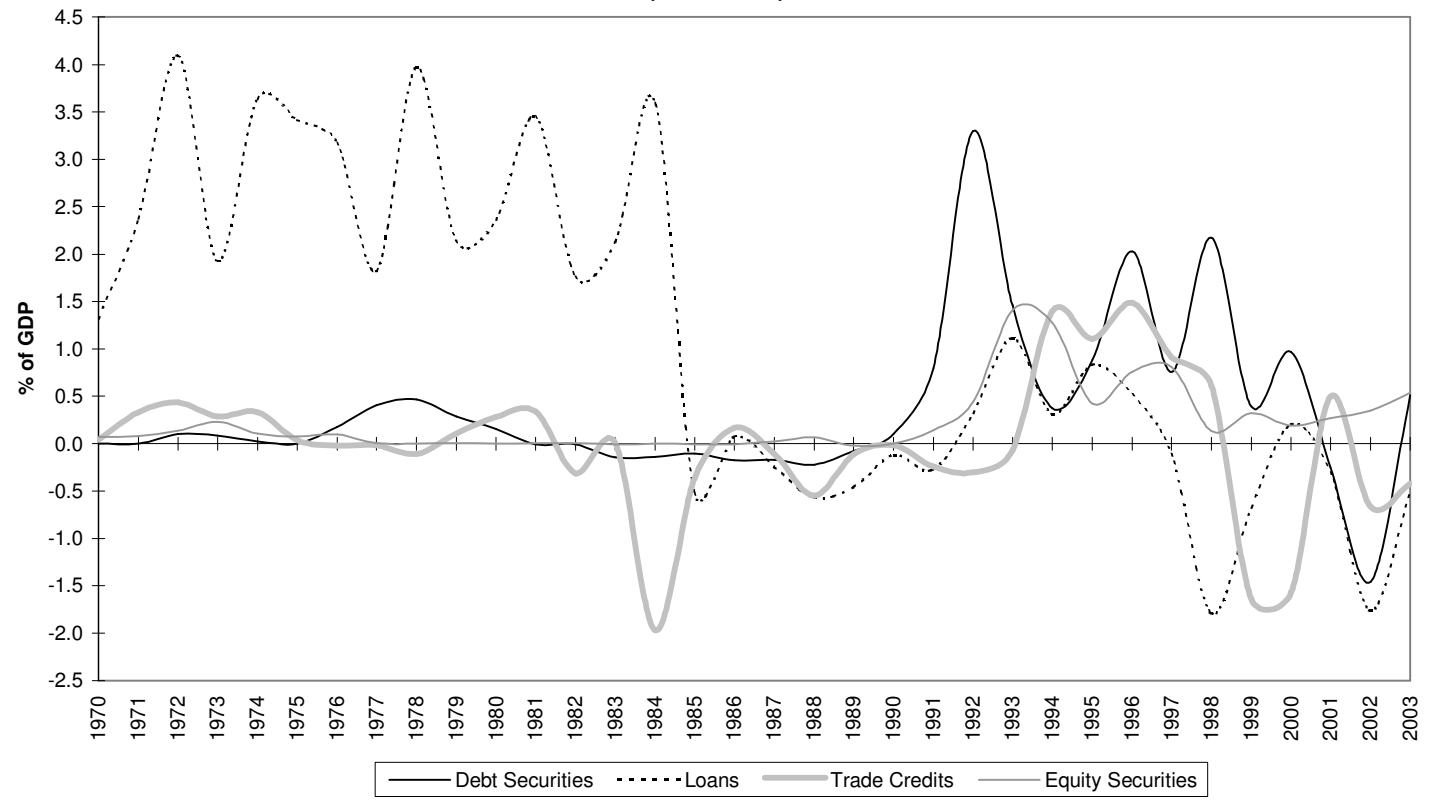

Figure 10

Net Foreign Direct Investment and Privatization as a proportion of GDP

(1990-2004)

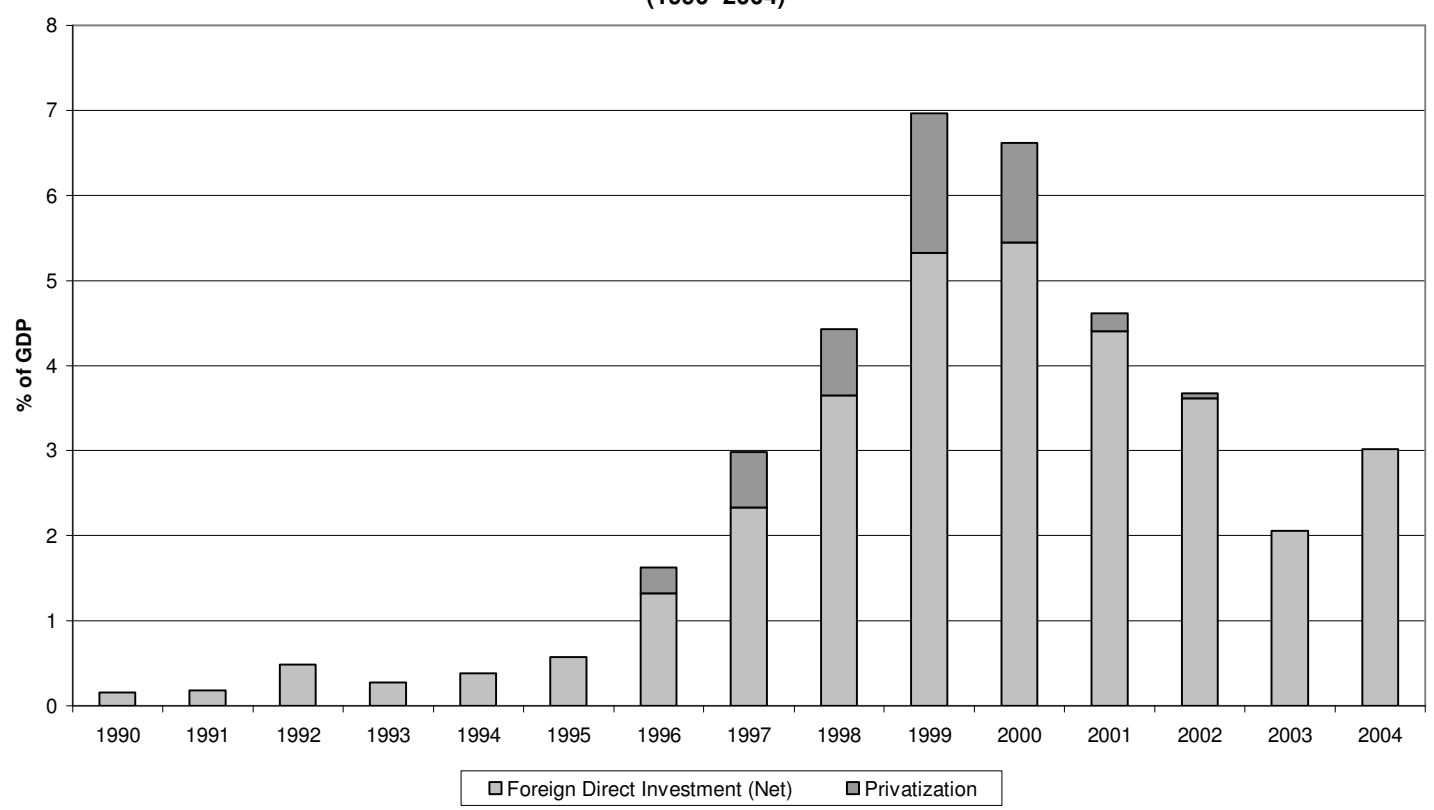


Figure 11

Private Capital Account and Official-Agency-Related Loans

(four-quarter cumulative balance - 1990:1-2004:2 - at 2003 prices)

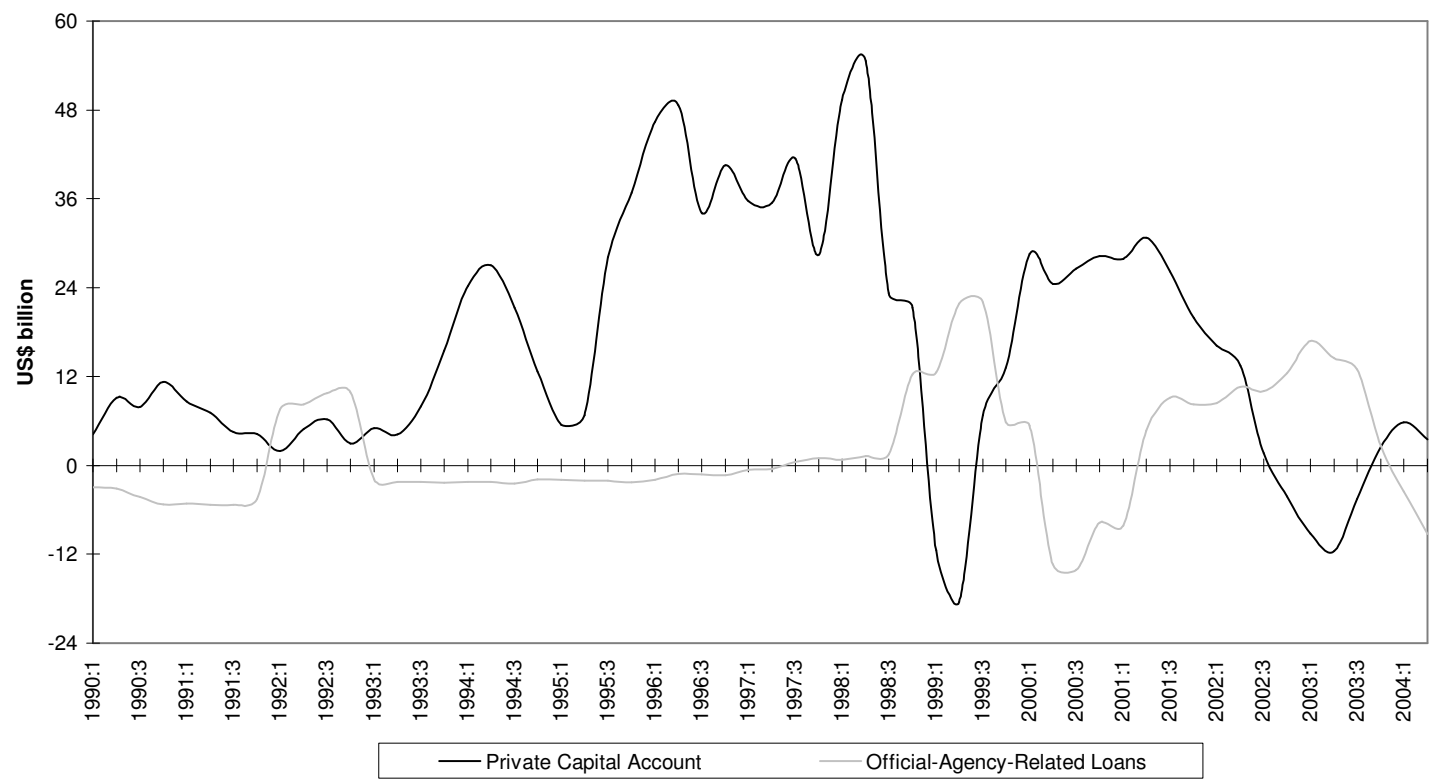

Figure 12

Short- and Long-Term Debt Net Flows

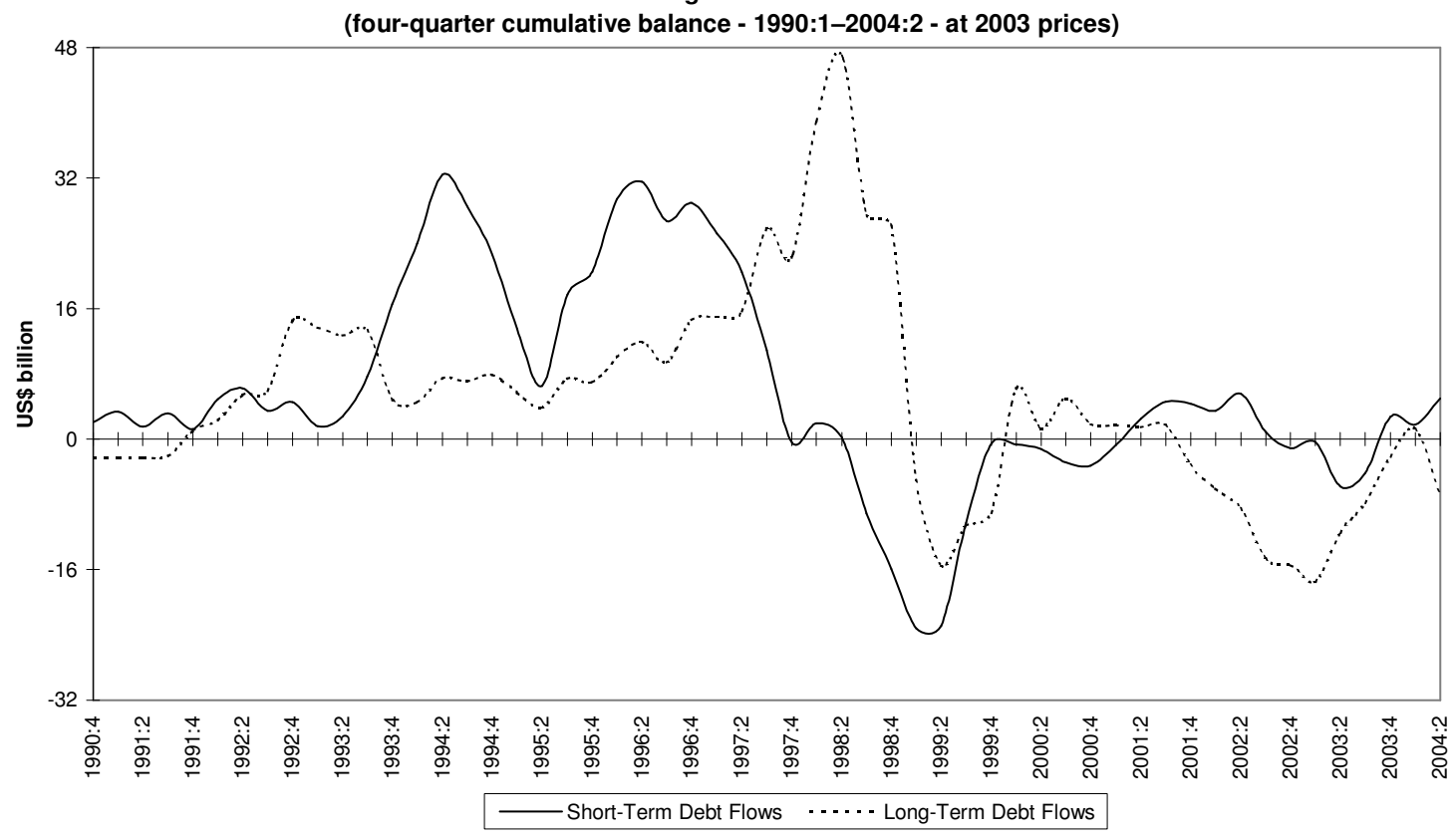


Figure 13

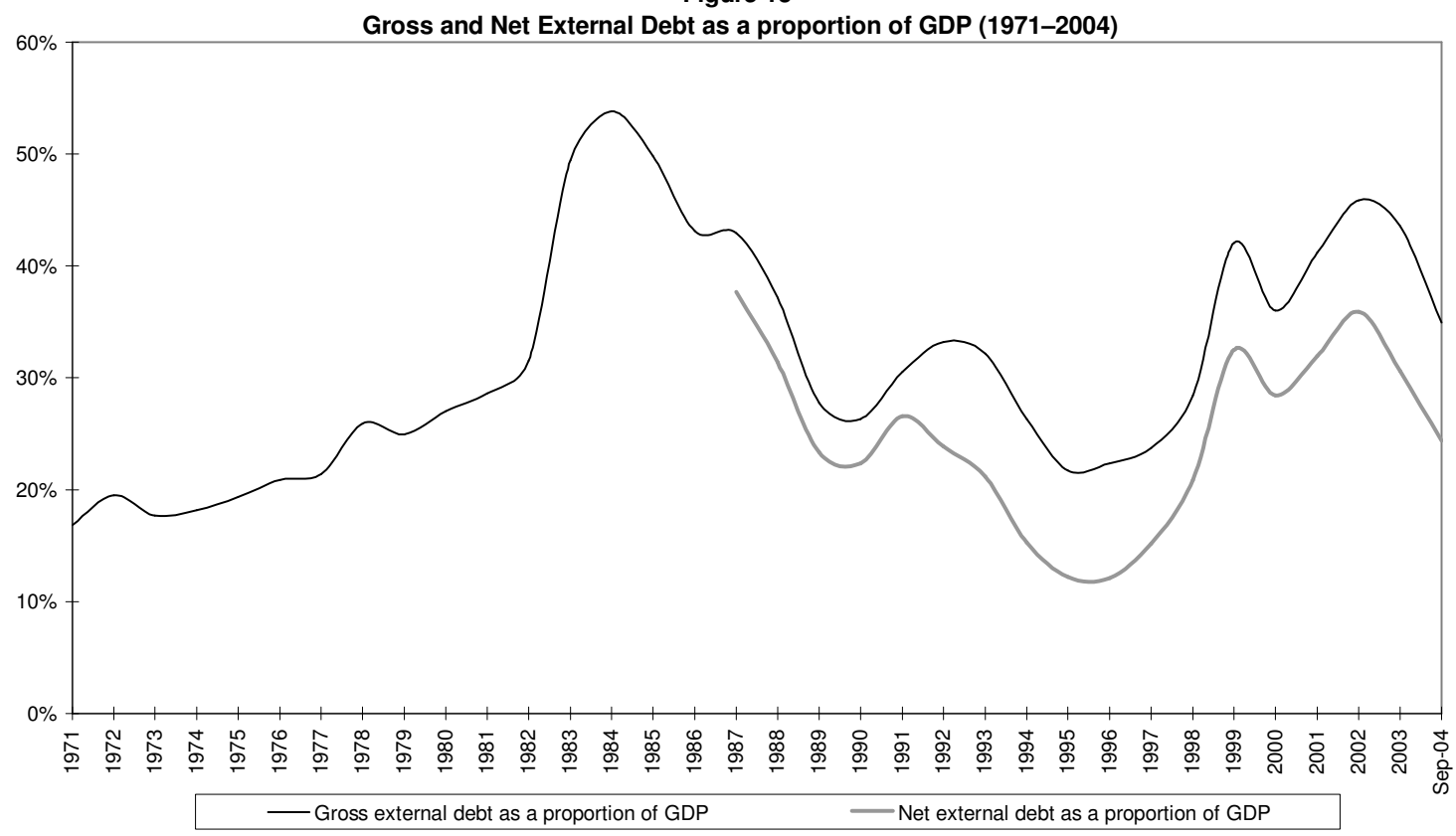

Note: Following IMF's recommendations, intercompany loans are excluded from external debt (starting in 1992 as data on these loans are not available previously).

Figure 14

Public and Private External Debt (1989-2004 - at 2003 prices)

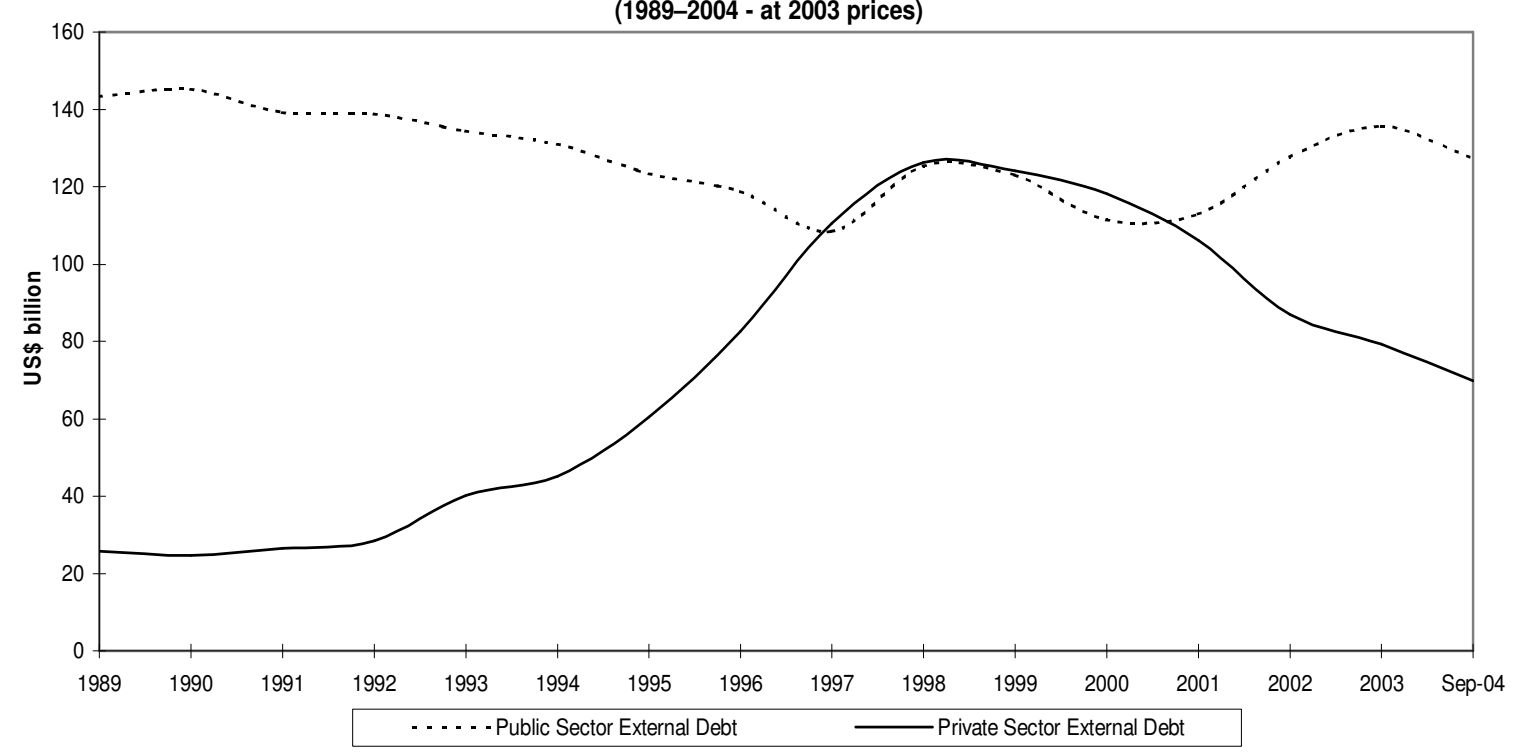


Figure 15

Ratio of Gross and Net External Debt to Exports (1971-2004)

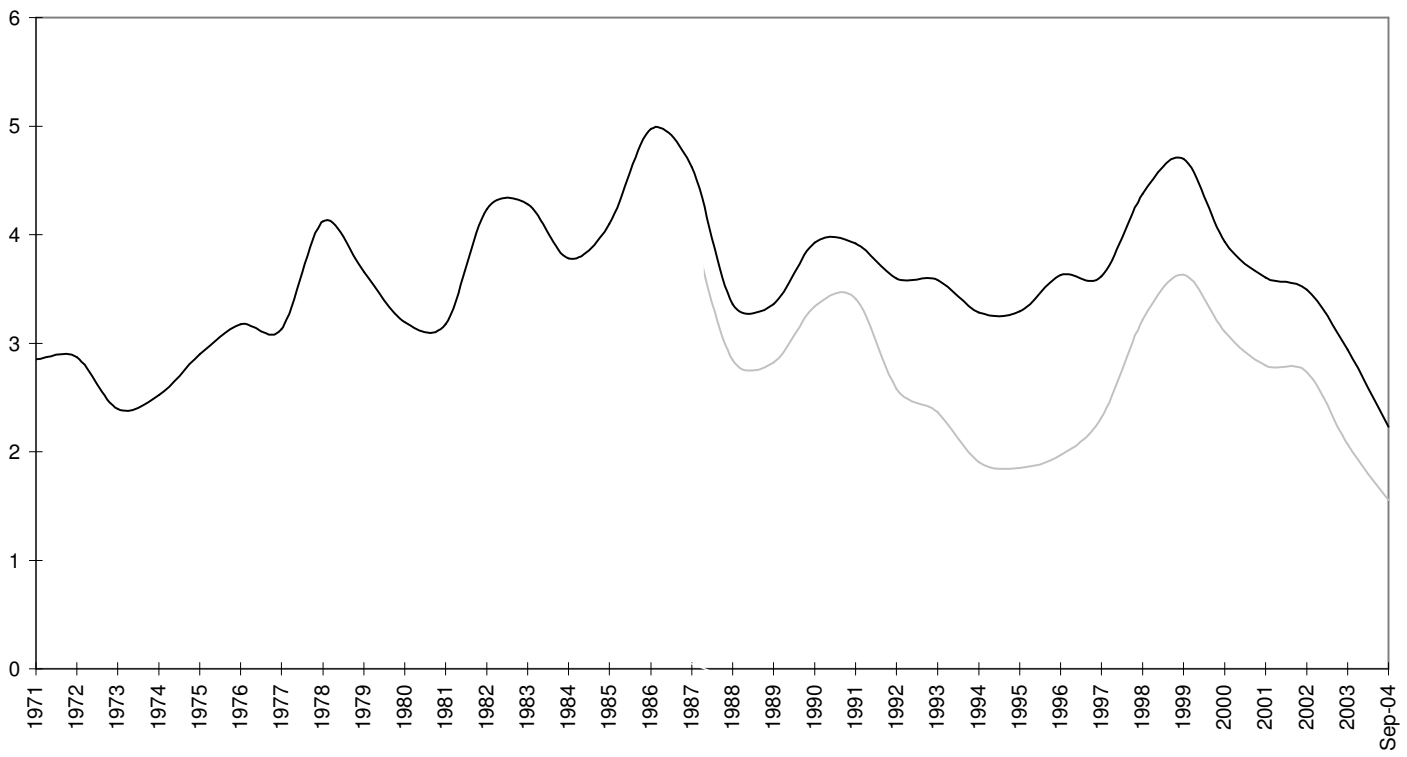

Gross External Debt

Figure 16

Ratio of Interest Payments to Exports (1970-2004)

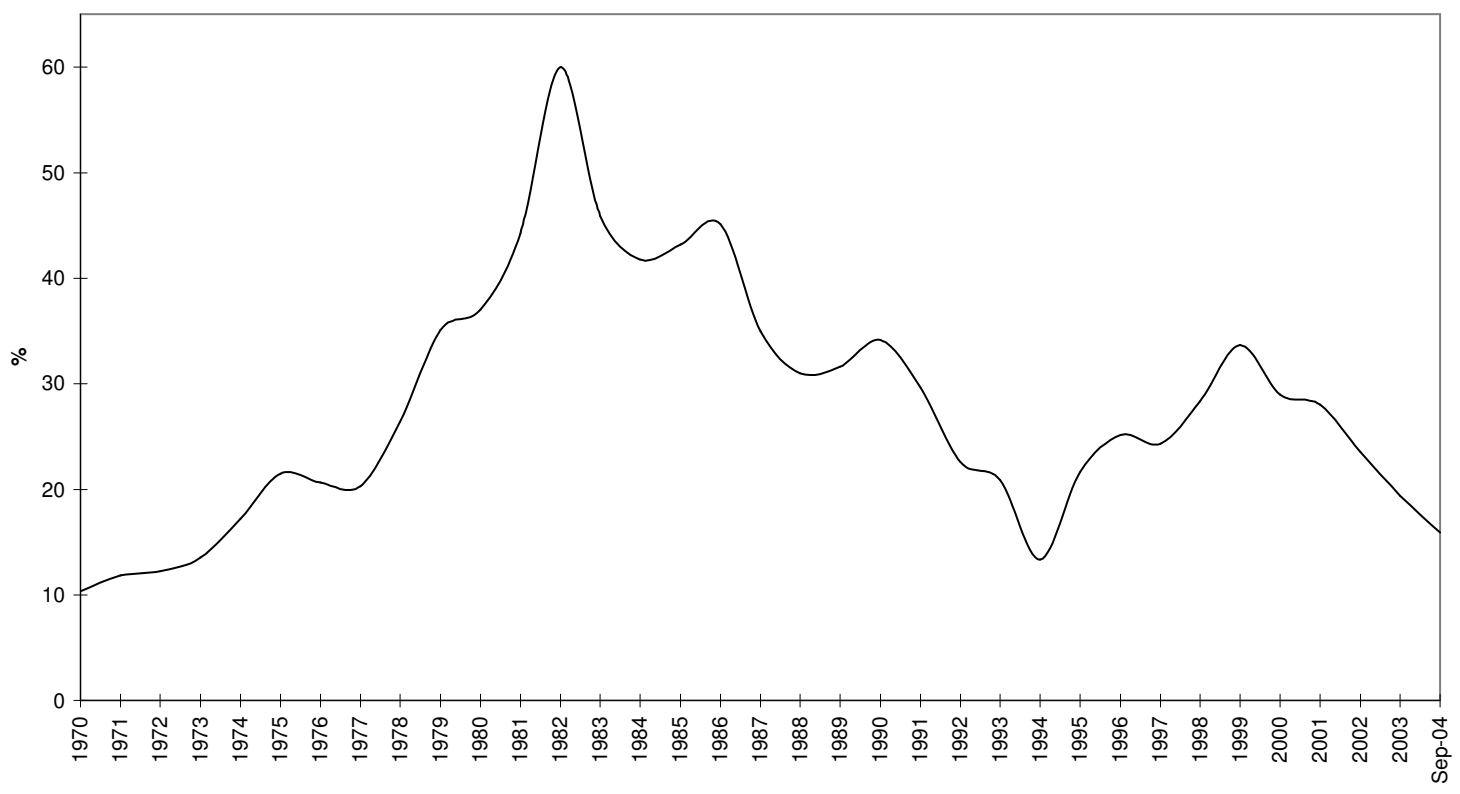


Figure 17

Cumulative Index of Capital Control -

Normalization 1989:12=100 (1990:01 - 2004:12)

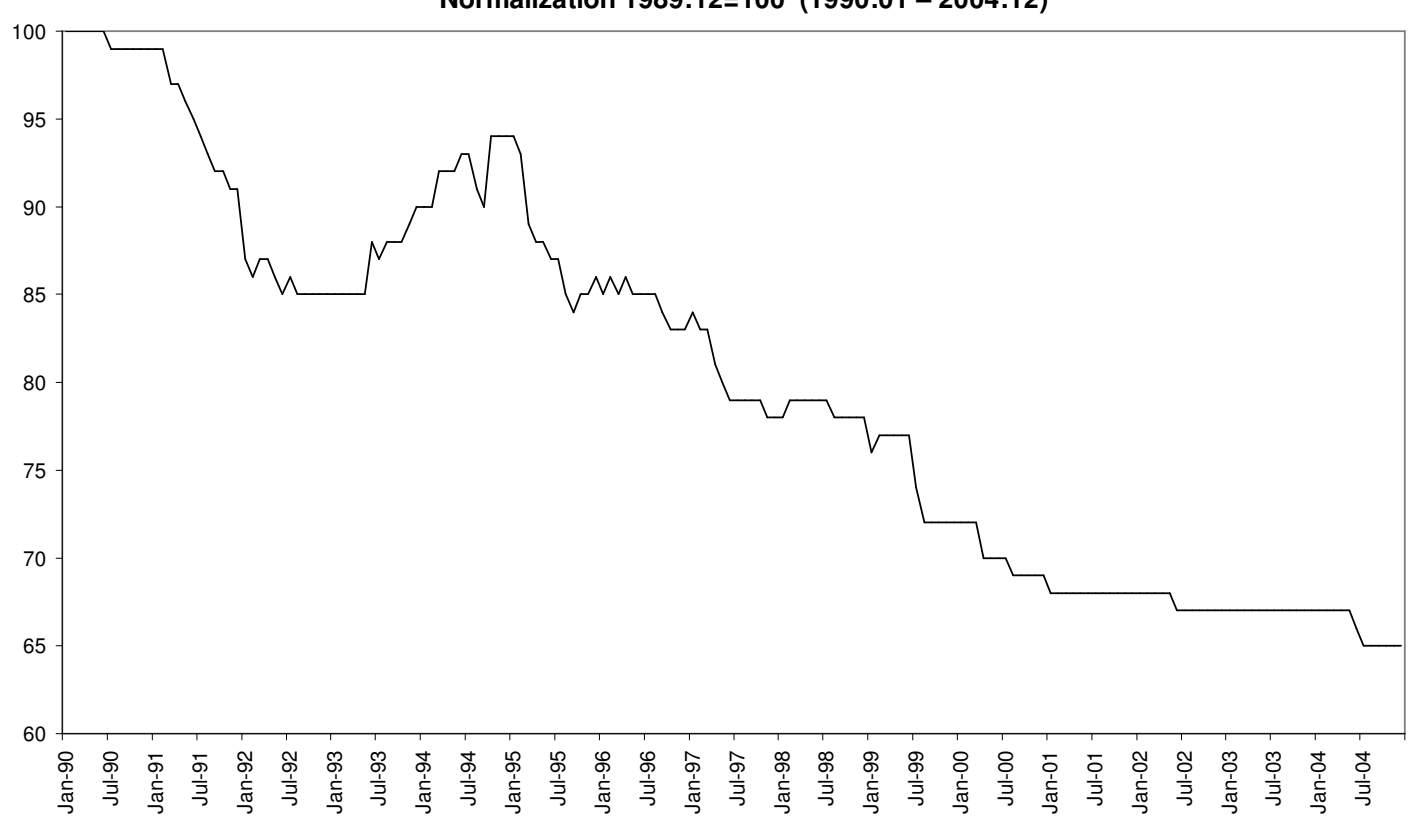

Note: Elaborated by the authors using the chronology in Appendix B. We have normalized December 1989 equal to 100 , and assigned -1 to each liberalizing measure and +1 to each restrictive one. Thus, the lower the index value, the lower the level of capital control.

Figure 18

Cumulative Index of Capital Control on Inflows and Outflows -

Normalization 1989:12=100 (1990:1 - 2004:12)

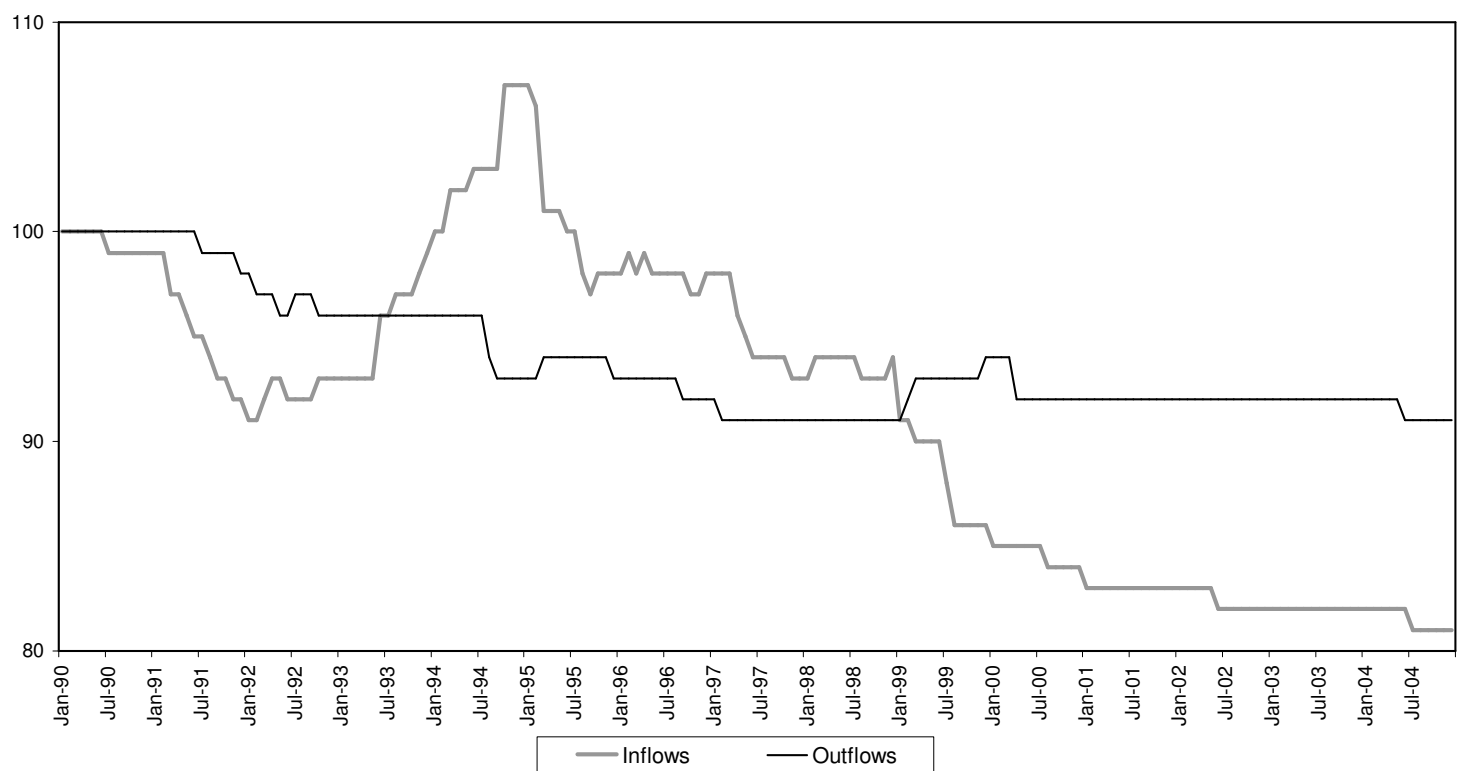

Note: See Figure 17.

63 
Figure 19

EMBI Brazil (1994:1-2004:10) - Sovereign Spread

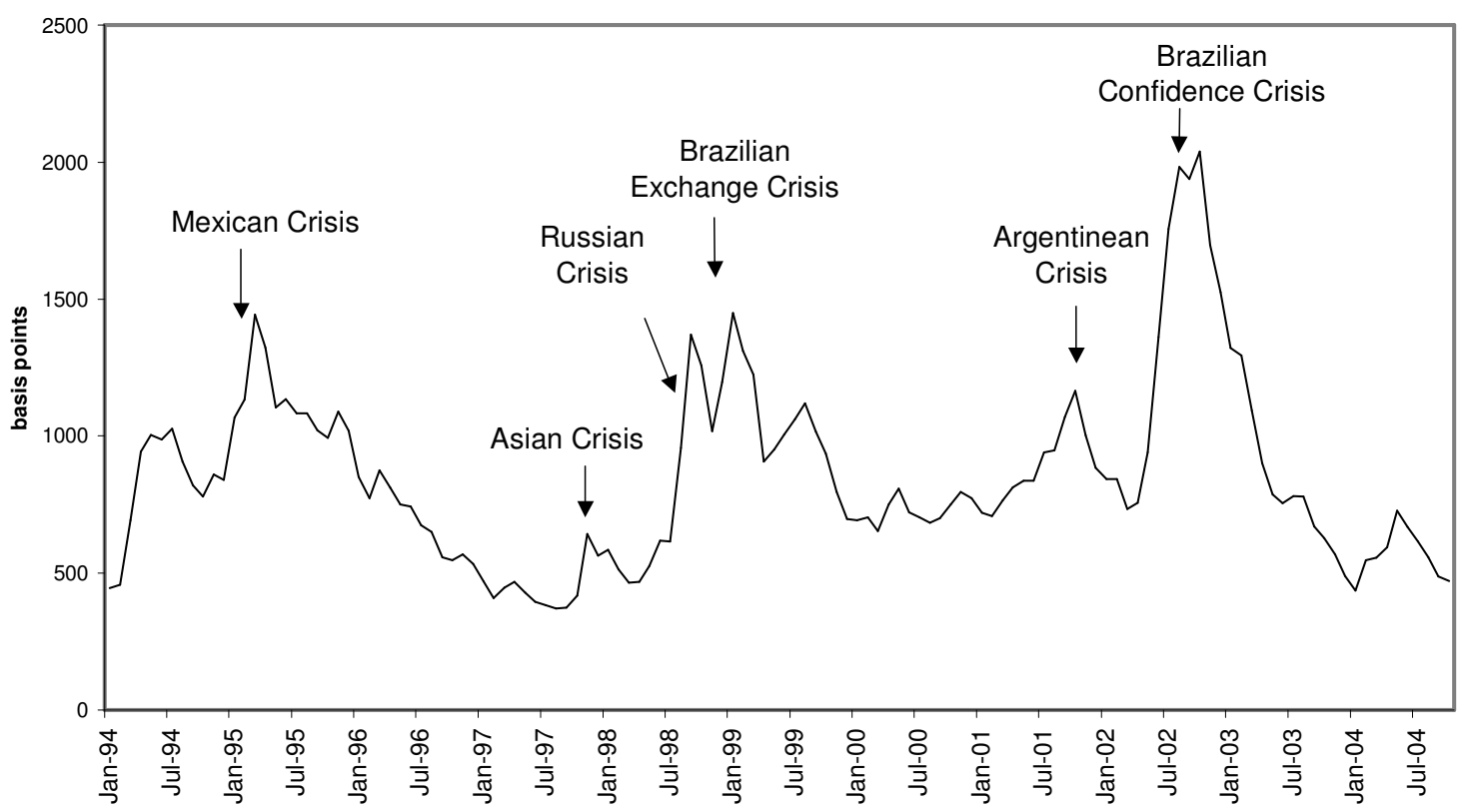

Figure 20.a

Foreign Portfolio Investments - Brazilian Company Equities: Inflows versus Outflows (four-quarter cumulative balance - 1990:4-2004:2 - at 2003 prices)

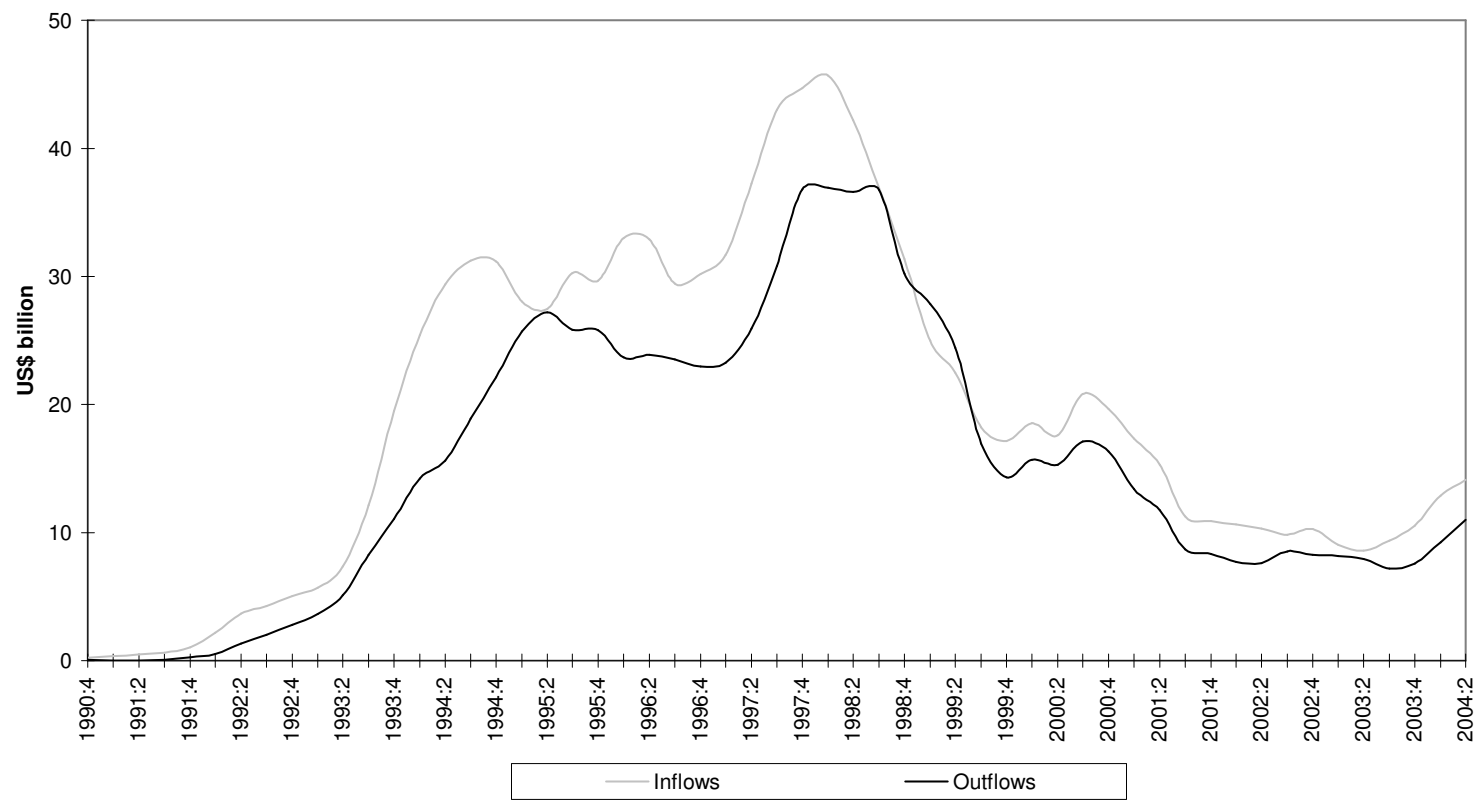


Figure 20.b

Foreign Portfolio Investment - Debt Securities: Inflows versus Outflows (four-quarter cumulative balance - 1990:4-2004:2 - at 2003 prices)

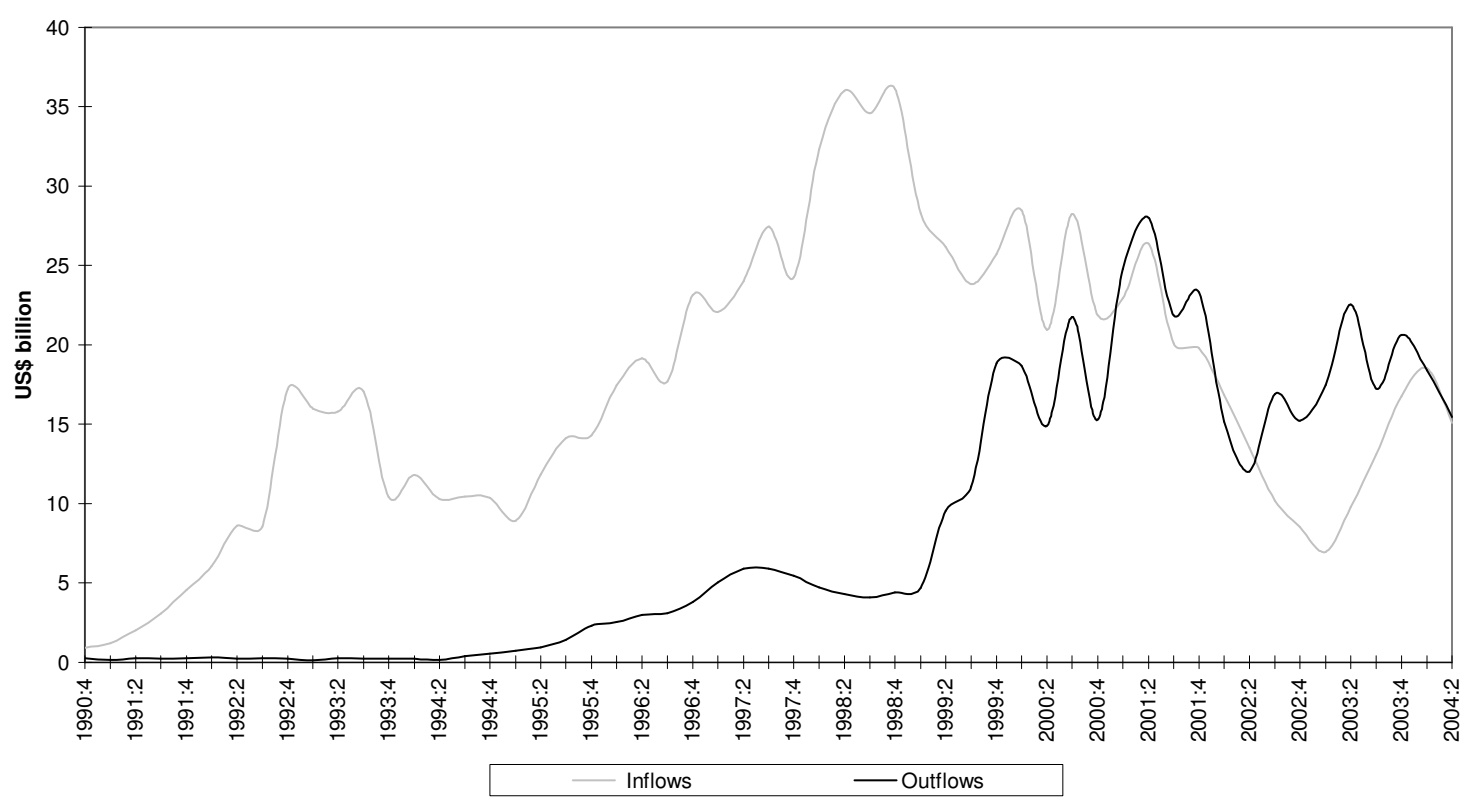

Figure 20.c

Other Foreign Investments - Other Long-Term Loans: Inflows versus Outflows (four-quarter cumulative balance - 1990:4-2004:2 - at 2003 prices)

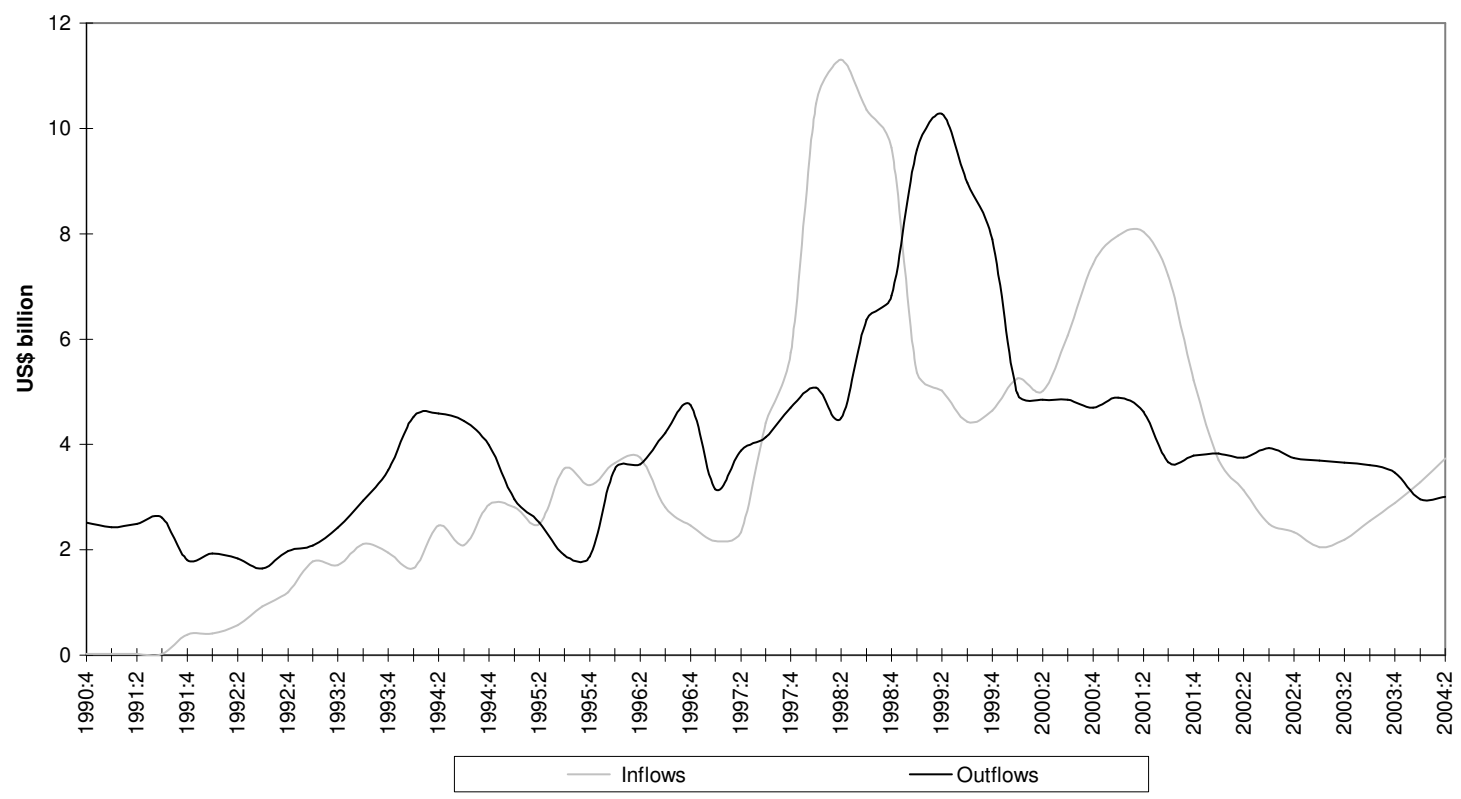


Figure 21

Capital and Financial Account, Current Account Deficit and Reserve Changes

(four-quarter cumulative balance - 1970:4-2004:2 - at 2003 prices)

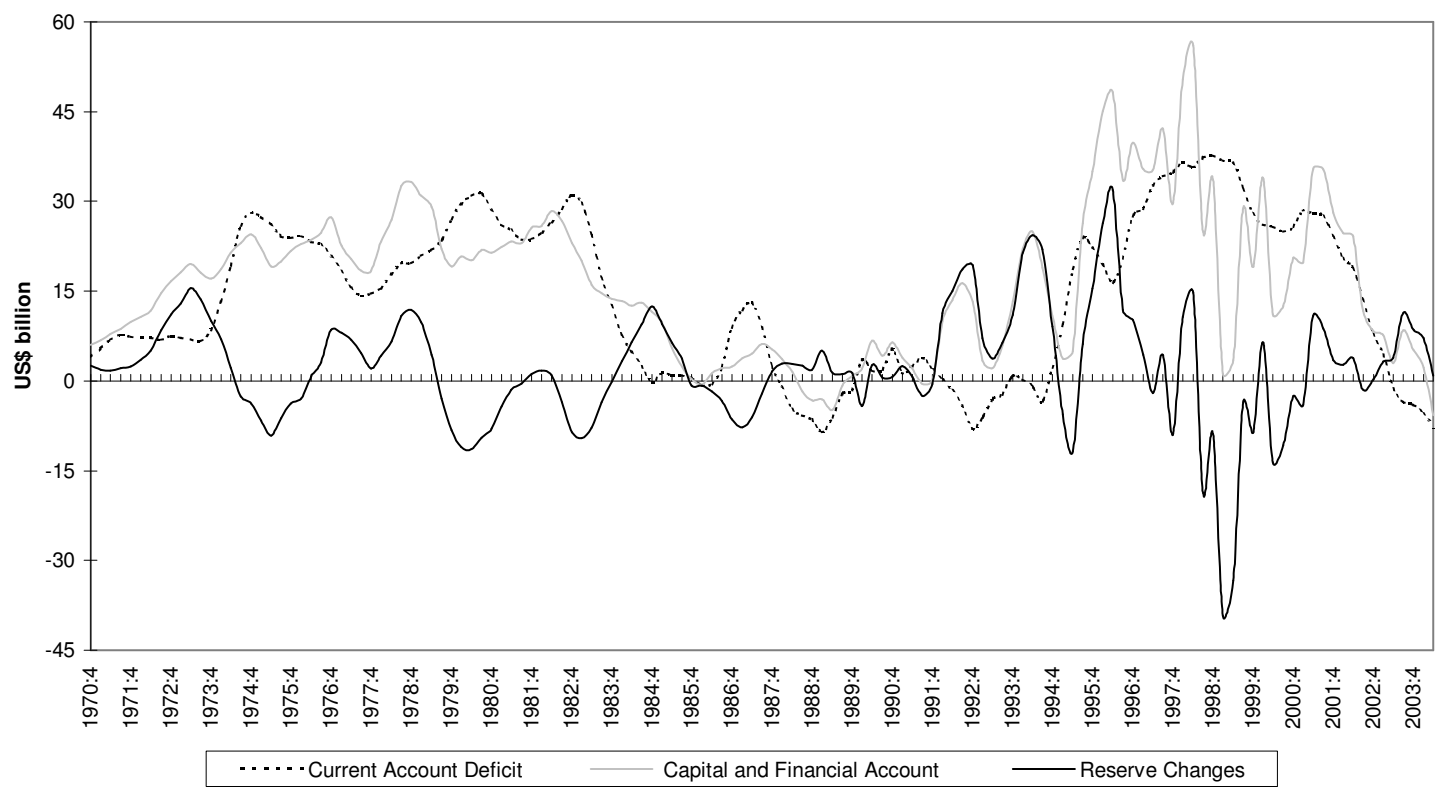

Figure 22

Share of the Capital and Finance Account Balance used for Current Account and for Change in Reserves

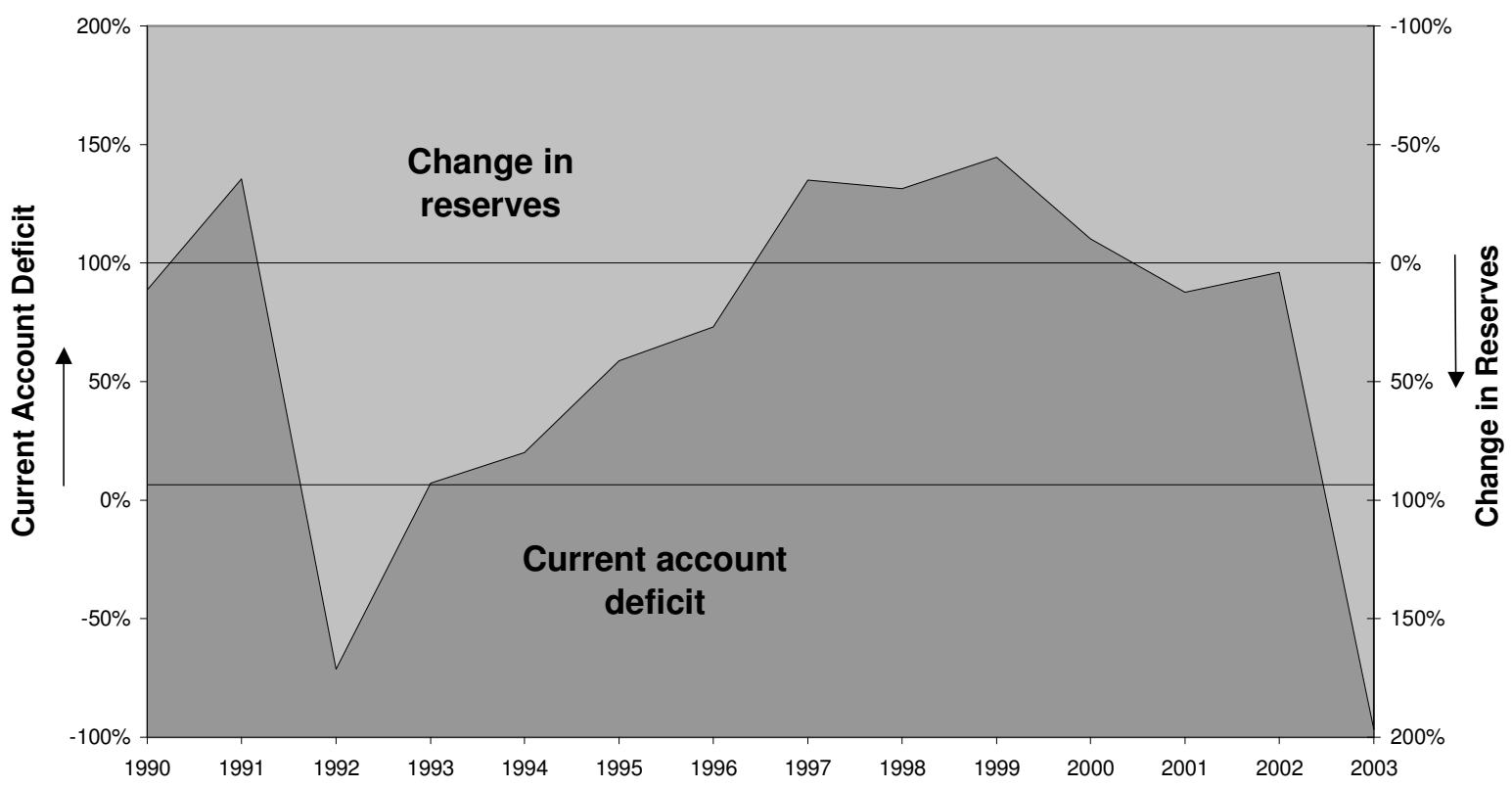


Figure 23

International Reserves - Liquidity Concept

(six-month moving average - at 2003 prices)

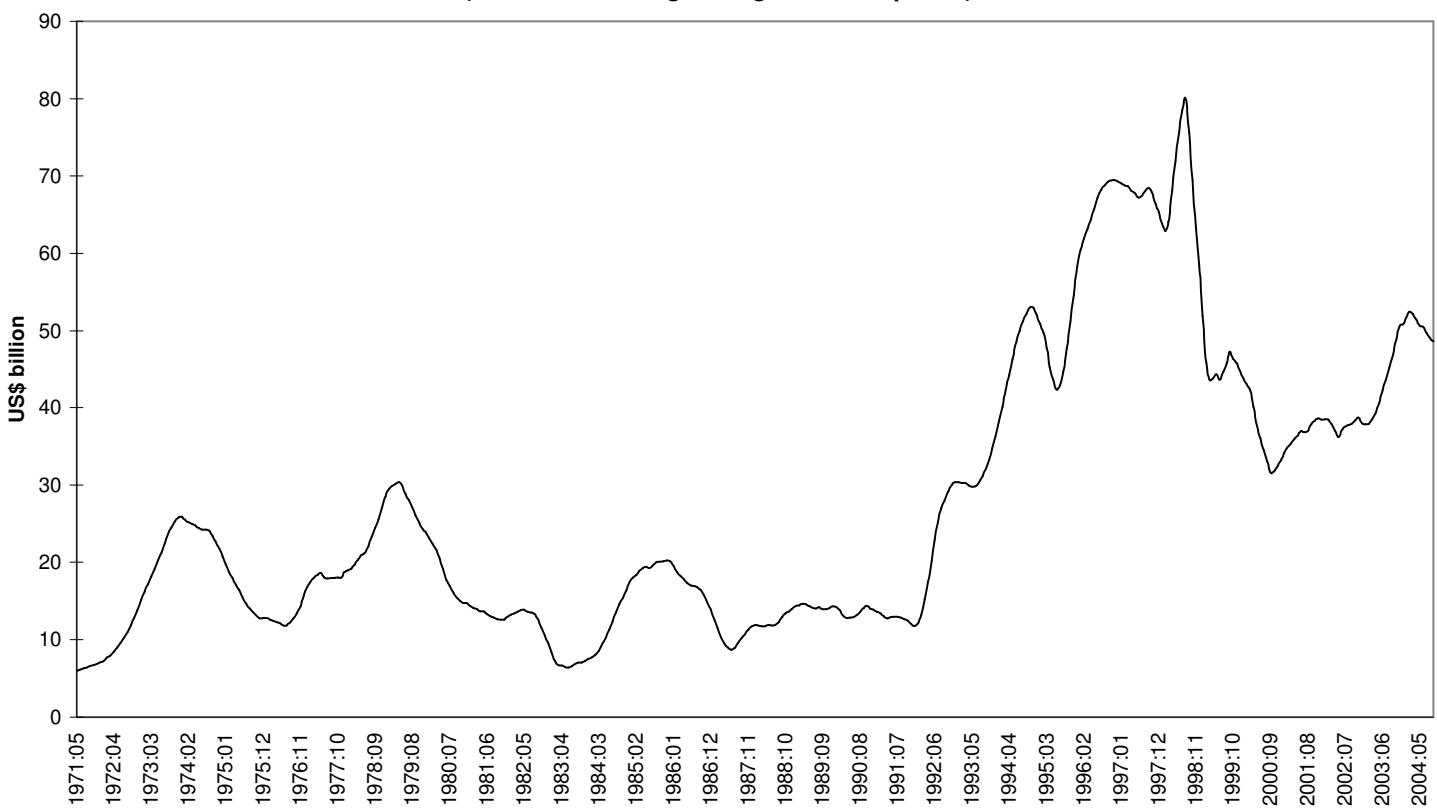

Figure 24

Components of National Accounts as a Proportion of GDP (1990-2003)

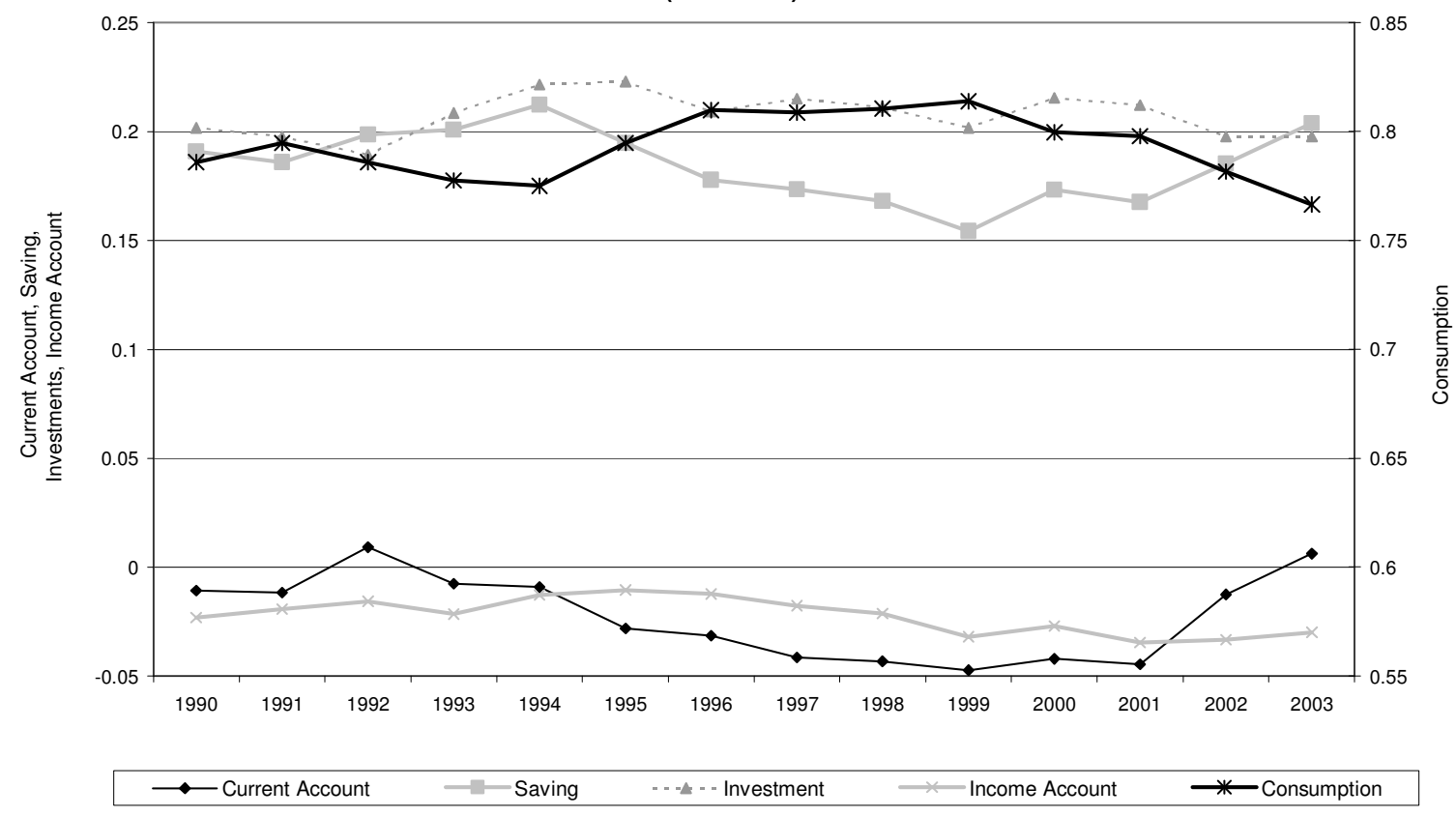


Figure 25

Private Capital Account Balance (four-quarter cumulative balance - at 2003 prices) and GDP Growth Rate (four-quarter moving average) - 1992:1-2004:2

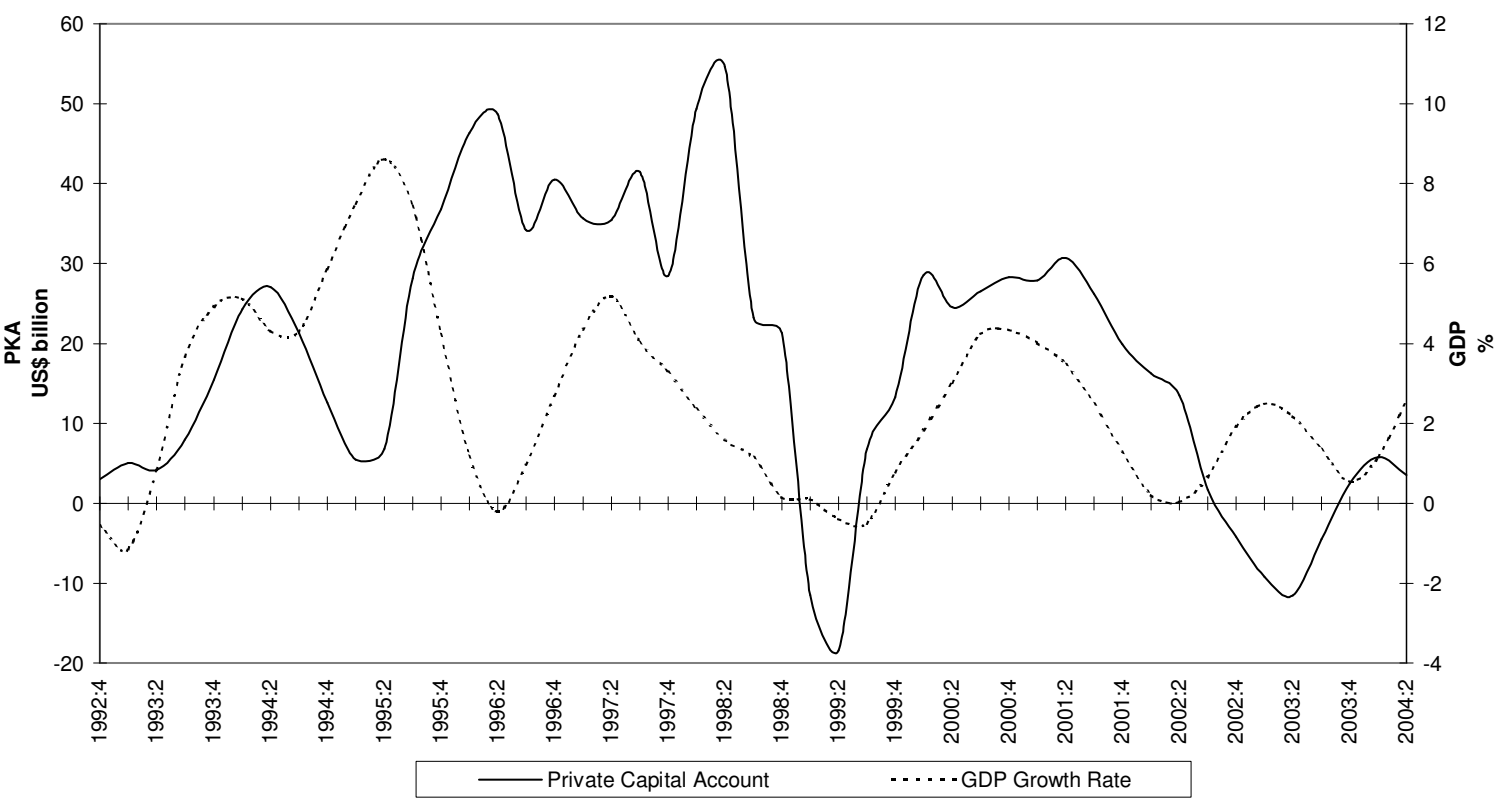

Figure 26

GDP Growth after Crises

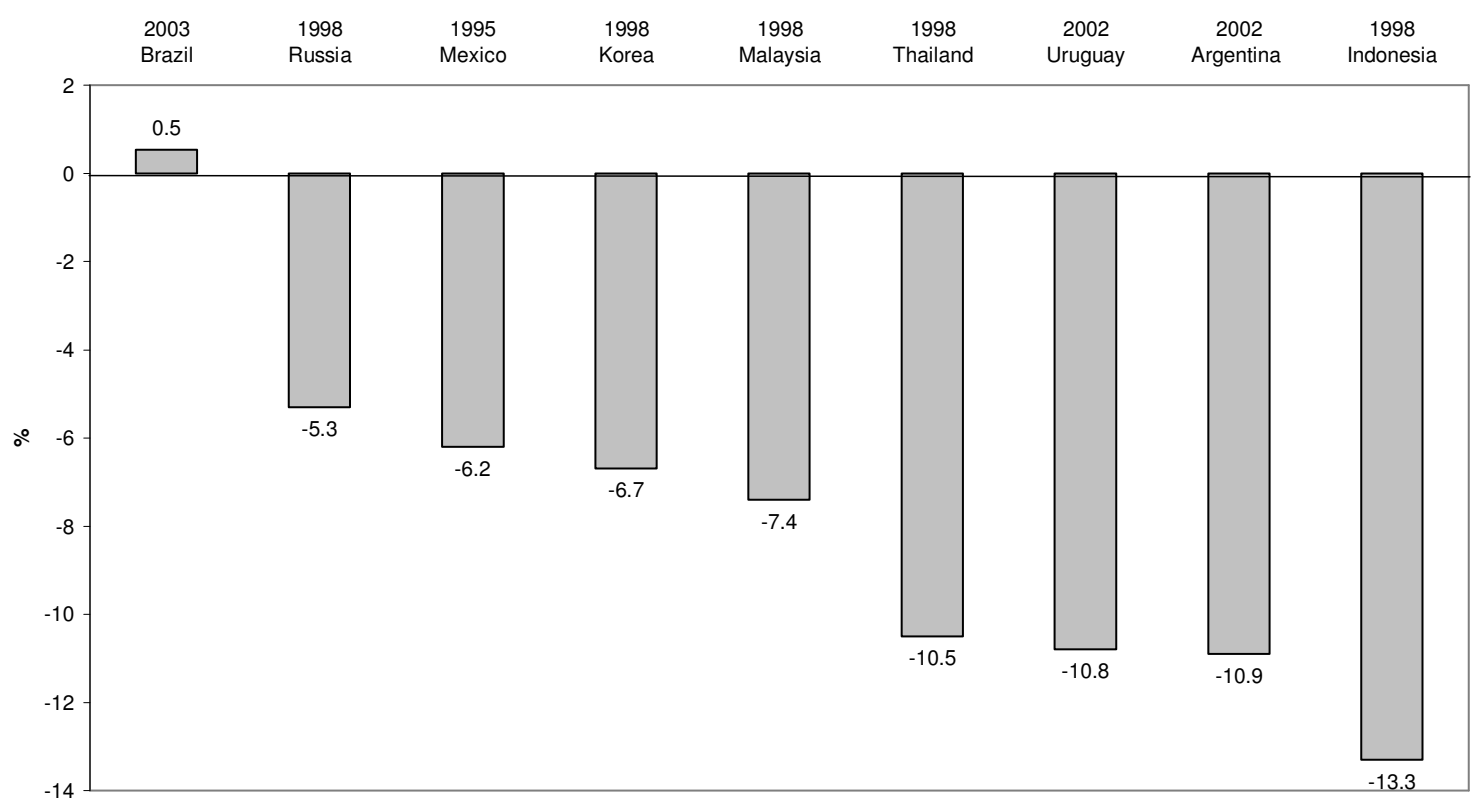


Figure 27

Impulse-Response Functions - SVAR (1995:01-2004:08)

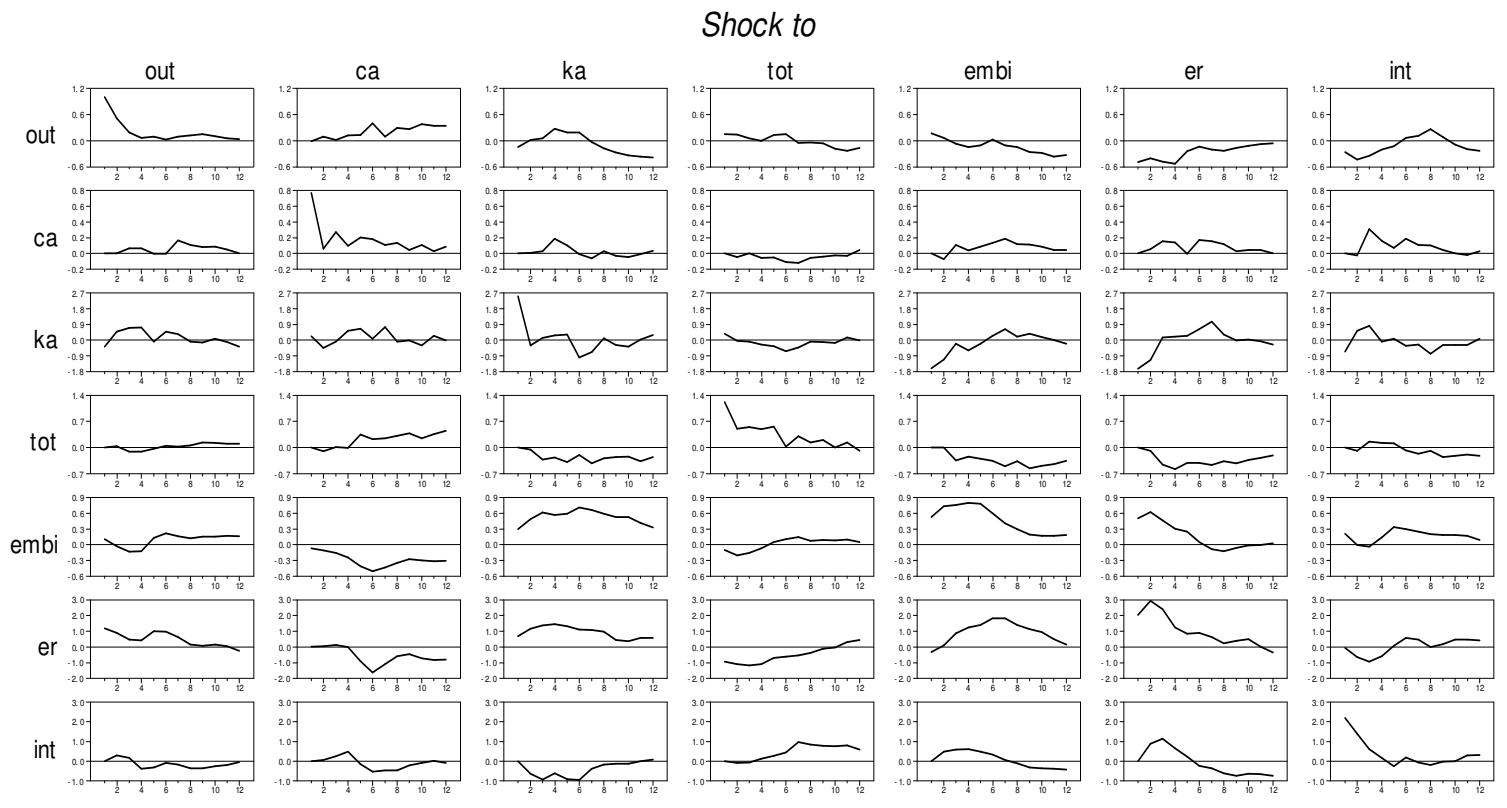


Table 1

Balance of Payments (\% of GDP) and GDP Growth

\begin{tabular}{|c|c|c|c|c|c|c|c|}
\hline & $\begin{array}{l}\text { Current } \\
\text { Account }\end{array}$ & $\begin{array}{c}\text { Trade } \\
\text { balance }\end{array}$ & $\begin{array}{c}\text { Capital and } \\
\text { Financial } \\
\text { Account }\end{array}$ & $\begin{array}{c}\text { Private } \\
\text { Capital } \\
\text { Account }\end{array}$ & $\begin{array}{l}\text { International } \\
\text { reserves - } \\
\text { Liquidity } \\
\text { concept }\end{array}$ & $\begin{array}{c}\text { GDP } \\
\text { Growth } \\
\text { Rate (\%) }\end{array}$ & $\begin{array}{c}\text { Per Capita } \\
\text { GDP } \\
\text { Growth } \\
\text { Rate (\%) }\end{array}$ \\
\hline 1970 & -1.97 & 0.54 & 3.01 & 1.75 & 2.79 & 10.40 & 7.20 \\
\hline 1971 & -3.31 & -0.70 & 4.42 & 3.14 & 3.50 & 11.34 & 8.42 \\
\hline 1972 & -2.87 & -0.41 & 6.46 & 5.53 & 7.12 & 11.94 & 9.05 \\
\hline 1973 & -2.48 & 0.01 & 4.89 & 3.91 & 7.63 & 13.97 & 11.07 \\
\hline 1974 & -6.80 & -4.25 & 5.92 & 4.82 & 4.77 & 8.15 & 5.45 \\
\hline 1975 & -5.39 & -2.73 & 4.91 & 4.14 & 3.11 & 5.17 & 2.58 \\
\hline 1976 & -4.17 & -1.46 & 5.52 & 4.93 & 4.25 & 10.26 & 7.60 \\
\hline 1977 & -2.72 & 0.05 & 3.47 & 2.78 & 4.09 & 4.93 & 2.45 \\
\hline 1978 & -3.47 & -0.51 & 5.91 & 5.17 & 5.91 & 4.97 & 2.54 \\
\hline 1979 & -4.79 & -1.27 & 3.41 & 2.87 & 4.34 & 6.76 & 4.34 \\
\hline 1980 & -5.36 & -1.19 & 4.04 & 3.56 & 2.91 & 9.20 & 6.80 \\
\hline 1981 & -4.53 & 0.47 & 4.93 & 4.36 & 2.90 & -4.25 & -6.34 \\
\hline 1982 & -6.00 & 0.29 & 4.46 & 1.95 & 1.47 & 0.83 & -1.34 \\
\hline 1983 & -3.57 & 3.42 & 3.92 & 3.29 & 2.41 & -2.93 & -4.99 \\
\hline 1984 & 0.05 & 6.90 & 3.44 & 0.96 & 6.32 & 5.40 & 3.20 \\
\hline 1985 & -0.12 & 5.91 & 0.09 & -0.91 & 5.50 & 7.85 & 5.64 \\
\hline 1986 & -2.06 & 3.22 & 0.56 & 0.35 & 2.62 & 7.49 & 5.35 \\
\hline 1987 & -0.51 & 3.96 & 1.15 & 1.35 & 2.64 & 3.53 & 1.56 \\
\hline 1988 & 1.37 & 6.28 & -0.69 & -1.09 & 2.99 & -0.06 & -1.88 \\
\hline 1989 & 0.25 & 3.88 & 0.15 & 0.42 & 2.33 & 3.16 & 1.36 \\
\hline 1990 & -0.81 & 2.29 & 0.98 & 1.72 & 2.13 & -4.35 & -5.95 \\
\hline 1991 & -0.35 & 2.61 & 0.04 & 0.78 & 2.32 & 1.03 & -0.66 \\
\hline 1992 & 1.58 & 3.93 & 2.57 & 0.60 & 6.13 & -0.54 & -2.15 \\
\hline 1993 & -0.16 & 3.10 & 2.44 & 2.85 & 7.50 & 4.92 & 3.26 \\
\hline 1994 & -0.33 & 1.93 & 1.60 & 1.86 & 7.15 & 5.85 & 4.20 \\
\hline 1995 & -2.61 & -0.49 & 4.12 & 4.33 & 7.35 & 4.22 & 2.62 \\
\hline 1996 & -3.03 & -0.72 & 4.38 & 4.46 & 7.75 & 2.66 & 1.10 \\
\hline 1997 & -3.77 & -0.84 & 3.19 & 3.07 & 6.46 & 3.27 & 1.72 \\
\hline 1998 & -4.24 & -0.83 & 3.77 & 2.37 & 5.66 & 0.13 & -1.36 \\
\hline 1999 & -4.72 & -0.22 & 3.23 & 2.26 & 6.77 & 0.79 & -0.71 \\
\hline 2000 & -4.02 & -0.12 & 3.21 & 4.40 & 5.48 & 4.36 & 2.82 \\
\hline 2001 & -4.55 & 0.52 & 5.31 & 3.75 & 7.04 & 1.31 & -0.17 \\
\hline 2002 & -1.66 & 2.86 & 1.74 & -0.92 & 8.23 & 1.93 & 0.45 \\
\hline 2003 & 0.82 & 4.89 & 1.01 & 0.50 & 9.73 & 0.54 & -0.92 \\
\hline 2004 & 1.94 & 5.60 & -1.22 & 0.07 & 8.80 & 4.94 & 3.44 \\
\hline
\end{tabular}

Source: Central Bank of Brazil (BCB), IBGE and authors' calculations. 
Table 2

Balance of Payments (\% of GDP) and GDP Growth - Period Averages

\begin{tabular}{lccccccc}
\hline Period & $\begin{array}{c}\text { Current } \\
\text { Account }\end{array}$ & $\begin{array}{c}\text { Trade } \\
\text { Balance }\end{array}$ & $\begin{array}{c}\text { Capital and } \\
\text { Financial } \\
\text { Account }\end{array}$ & $\begin{array}{c}\text { Private } \\
\text { Capital } \\
\text { Account }\end{array}$ & $\begin{array}{c}\text { International } \\
\text { Reserves }- \\
\text { Liquidity } \\
\text { concept }\end{array}$ & $\begin{array}{c}\text { GDP } \\
\text { Rate }\end{array}$ & $\begin{array}{c}\text { Per Capita } \\
\text { GDP } \\
\text { Growth } \\
\text { Rate }\end{array}$ \\
\hline $1974-1982$ & -4.80 & -1.18 & 4.73 & 3.84 & 3.75 & 5.03 & 2.59 \\
$1983-1994$ & -0.39 & 3.95 & 1.35 & 1.01 & 4.17 & 2.54 & 0.68 \\
$1995-1998$ & -3.41 & -0.72 & 3.87 & 3.56 & 6.80 & 2.56 & 1.01 \\
$1999-2001$ & -4.43 & 0.06 & 3.91 & 3.47 & 6.43 & 2.14 & 0.63 \\
$2002-2004$ & 0.37 & 4.45 & 0.51 & -0.11 & 8.92 & 2.45 & 0.97 \\
\hline
\end{tabular}

Source: BCB, IBGE and authors' calculations.

Table 3

Net Capital Flows by Groups - Ratio to GDP

\begin{tabular}{ccccccccc}
\hline Period & $\begin{array}{c}\text { Direct } \\
\text { Investment }\end{array}$ & $\begin{array}{c}\text { Equity } \\
\text { Securities }\end{array}$ & $\begin{array}{c}\text { Debt } \\
\text { Securities }\end{array}$ & Loans & $\begin{array}{c}\text { Trade } \\
\text { Credits }\end{array}$ & $\begin{array}{c}\text { Other Short- } \\
\text { term assets }\end{array}$ & $\begin{array}{c}\text { Official } \\
\text { Agencies }\end{array}$ & Other Items \\
\hline $1974-1982$ & 0.56 & 0.03 & 0.17 & 2.86 & 0.07 & 0.20 & 0.53 & -0.04 \\
$1983-1991$ & 0.20 & 0.02 & -0.02 & 0.40 & -0.36 & 0.12 & 0.11 & 0.40 \\
$1992-2004$ & 2.27 & 0.56 & 0.77 & -0.18 & 0.08 & -0.91 & 0.42 & -0.40 \\
$1992-1996$ & 0.53 & 0.86 & 1.61 & 0.62 & 0.72 & -0.61 & 0.16 & -1.14 \\
$1997-2004$ & 3.36 & 0.36 & 0.25 & -0.68 & -0.31 & -1.10 & 0.59 & 0.07 \\
\hline
\end{tabular}

Source: BCB and authors' calculations.

Notes: The values of debt securities, portfolio investment and loans exclude the values related to the debt conversion under the Brady Plan.

Table 4

Volatilities of Net Capital Flows

(quarterly data - 1992:1-2004:2 - US\$ million - at 2003 prices)

\begin{tabular}{lccccccccc}
\hline & $\begin{array}{c}\text { Direct } \\
\text { Investment }\end{array}$ & $\begin{array}{c}\text { Equity } \\
\text { Securities }\end{array}$ & $\begin{array}{c}\text { Debt } \\
\text { Securities }\end{array}$ & $\begin{array}{c}\text { Portfolio } \\
\text { Investment }\end{array}$ & Loans & $\begin{array}{c}\text { Trade credit Short-Term } \\
\text { Assets }\end{array}$ & $\begin{array}{c}\text { Short- } \\
\text { Term } \\
\text { Flows }\end{array}$ & $\begin{array}{c}\text { Long-Term } \\
\text { Flows }\end{array}$ \\
\hline Standard Deviation & 3077 & 1668 & 3718 & 4084 & 2813 & 2284 & 1799 & 4582 & 5166 \\
Mean & 3717 & 947 & 1559 & 2488 & -100 & 2601 & -1712 & 1645 & 1102 \\
Variation Coefficient & 0.83 & 1.76 & 2.39 & 1.64 & -28.12 & 0.88 & -1.05 & 2.78 & 4.69 \\
\hline Source: BCB and authors' calculations. & & & & & & & & &
\end{tabular}

Notes: See table 3. 
Table 5

Volatilities of Inflows and Outflows

(quarterly data - 1992:1-2004:2 - US\$ million - at 2003 prices)

\begin{tabular}{|c|c|c|c|c|c|c|c|}
\hline & $\begin{array}{l}\text { Foreign Direct } \\
\text { Investment }\end{array}$ & $\begin{array}{l}\text { Foreign Portfolio } \\
\text { Investment }\end{array}$ & $\begin{array}{l}\text { Brazilian } \\
\text { Company Equity }\end{array}$ & Debt Securities & $\begin{array}{l}\text { Other Long-Term } \\
\text { Loans }\end{array}$ & $\begin{array}{c}\text { Long-Term } \\
\text { Suppliers' Trade } \\
\text { Credits }\end{array}$ & $\begin{array}{l}\text { Long-Term } \\
\text { Buyers' Trade } \\
\text { Credits }\end{array}$ \\
\hline \multicolumn{8}{|l|}{ Inflows } \\
\hline Standard Deviation & 3852 & 5007 & 3112 & 2916 & 846 & 893 & 1006 \\
\hline Mean & 5253 & 10046 & 5356 & 4690 & 1027 & 693 & 952 \\
\hline Variation Coefficient & 0.73 & 0.50 & 0.58 & 0.62 & 0.82 & 1.29 & 1.06 \\
\hline \multicolumn{8}{|l|}{ Outflows } \\
\hline Standard Deviation & 965 & 4310 & 2719 & 2731 & 649 & 677 & 927 \\
\hline Mean & 1287 & 7371 & 4268 & 2343 & 1051 & 722 & 1116 \\
\hline Variation Coefficient & 0.75 & 0.58 & 0.64 & 1.17 & 0.62 & 0.94 & 0.83 \\
\hline
\end{tabular}

Source: BCB and authors' calculations.

Notes: See table 3.

Table 6

Correlations across Capital Flows

(quarterly data - 1992:1-2004:2 - at 2003 prices)

\begin{tabular}{|c|c|c|c|c|c|c|}
\hline & $\begin{array}{c}\text { Equity } \\
\text { Securities }\end{array}$ & Debt Securities & Loans & Trade Credit & $\begin{array}{c}\text { Portfolio } \\
\text { Investment }\end{array}$ & $\begin{array}{c}\text { Direct } \\
\text { Investment }\end{array}$ \\
\hline Equity Securities & 1.00 & 0.27 & 0.34 & 0.43 & 0.48 & -0.28 \\
\hline Debt Securities & 0.27 & 1.00 & 0.36 & 0.15 & 0.97 & -0.11 \\
\hline Loans & 0.34 & 0.36 & 1.00 & 0.15 & 0.41 & -0.38 \\
\hline Trade Credit & 0.43 & 0.15 & 0.15 & 1.00 & 0.24 & 0.16 \\
\hline $\begin{array}{l}\text { Portfolio } \\
\text { Investments }\end{array}$ & 0.48 & 0.97 & 0.41 & 0.24 & 1.00 & -0.17 \\
\hline $\begin{array}{l}\text { Direct } \\
\text { Investments }\end{array}$ & -0.28 & -0.11 & -0.38 & 0.16 & -0.17 & 1.00 \\
\hline
\end{tabular}

Notes: See table 3.

Table 7

Private Capital Account Balance and Crises (US\$ million - at current prices)

\begin{tabular}{llccc}
\hline \multirow{2}{*}{ Crises } & Period & $\begin{array}{c}\text { Pour-Quarter } \\
\text { Average Before } \\
\text { Crisis }\end{array}$ & $\begin{array}{c}\text { Quarterly } \\
\text { Average During } \\
\text { the Crises }\end{array}$ & Difference \\
\cline { 3 - 5 } Mexican & $1994: 4-1995: 1$ & 4,242 & 196 & 4,046 \\
Asian & $1997: 4$ & 9,000 & 1,364 & 7,636 \\
Russian & $1998: 3$ & 12,014 & $-17,290$ & 29,304 \\
Exchange Crisis & $1999: 1$ & 4,662 & $-5,499$ & 10,161 \\
Argentinian & $1998: 3-1999: 1$ & 12,014 & $-7,724$ & 19,738 \\
Confidence Crisis & $2001: 4$ & 6,264 & 1,454 & 4,810 \\
& $2002: 3-2002: 4$ & 3,271 & $-6,363$ & 9,634 \\
\hline Source: BCB and authors' & $2002: 2002: 4$ & 3,918 & $-3,045$ & 6,962 \\
\hline
\end{tabular}

Source: BCB and authors' calculations. 
Table 8

Correlation between Private Capital Account

and the Items Current Account and Change in Reserves

\begin{tabular}{ccccc}
\hline & \multicolumn{4}{c}{ Private Capital Account } \\
\cline { 2 - 5 } & $1974: 11991: 4$ & $1992: 12004: 2$ & $1992: 11998: 4$ & $1999: 12004: 2$ \\
\hline Current Account & & & \\
lag (-4) & -0.178 & 0.005 & 0.039 & -0.216 \\
lag (-3) & -0.320 & -0.190 & -0.193 & -0.312 \\
lag (-2) & -0.334 & -0.238 & -0.267 & -0.365 \\
lag (-1) & -0.384 & -0.284 & -0.280 & -0.501 \\
contemporary & -0.367 & -0.262 & -0.148 & -0.544 \\
lead (+1) & -0.351 & -0.235 & -0.130 & -0.501 \\
lead (+2) & -0.442 & -0.338 & -0.361 & -0.460 \\
lead (+3) & -0.458 & -0.381 & -0.353 & -0.507 \\
lead (+4) & -0.486 & -0.418 & -0.316 & -0.454 \\
Change in Reserves & & & & \\
contemporary & 0.329 & 0.704 & 0.766 & 0.427 \\
\hline
\end{tabular}

Source: BCB and authors' calculations

*Seasonally Adjusted

Table 9

Domestic Saving and Investment as a Share of GDP and their

Contribution to the Increase in the Current Account Deficit -

1990-2001

\begin{tabular}{|c|c|c|c|}
\hline & $\begin{array}{l}\text { Current } \\
\text { Account Deficit } \\
\text { (a) }=(c)-(b)\end{array}$ & $\begin{array}{l}\text { Domestic } \\
\text { Saving } \\
\text { (b) }\end{array}$ & $\begin{array}{l}\text { Investment } \\
\text { (c) }\end{array}$ \\
\hline 1990-1994 (1) & $0.6 \%$ & $19.8 \%$ & $20.4 \%$ \\
\hline $1995-1997$ (2) & $3.4 \%$ & $18.2 \%$ & $21.6 \%$ \\
\hline $1998-2001$ (3) & $4.4 \%$ & $16.6 \%$ & $21.0 \%$ \\
\hline$(2)-(1)$ & 2.8 & -1.6 & 1.2 \\
\hline $\begin{array}{l}\text { Contribution to the increase } \\
\text { in the CA deficit }\end{array}$ & $100.0 \%$ & $56.8 \%$ & $43.2 \%$ \\
\hline (3) $-(2)$ & 1.1 & -1.6 & -0.6 \\
\hline $\begin{array}{c}\text { Contribution to the increase } \\
\text { in the CA deficit }\end{array}$ & $100.0 \%$ & $153.2 \%$ & $-53.2 \%$ \\
\hline
\end{tabular}

Source: IBGE and authors' calculations.

Table 10

Components of National Accounts as a Share of GDP and their Contribution to the Increase in the Current Account Deficit - 1990-2001

\begin{tabular}{|c|c|c|c|c|c|c|}
\hline & $\begin{array}{c}\text { Current } \\
\text { Account Deficit }\end{array}$ & Income Deficit & Investment & Consumption & $\begin{array}{l}\text { Household } \\
\text { Consumption }\end{array}$ & $\begin{array}{l}\text { Government } \\
\text { Consumption }\end{array}$ \\
\hline 1990-1994 (1) & $0.6 \%$ & $1.8 \%$ & $20.4 \%$ & $78.4 \%$ & $60.4 \%$ & $18.0 \%$ \\
\hline 1995-1997 (2) & $3.4 \%$ & $1.4 \%$ & $21.6 \%$ & $80.4 \%$ & $61.7 \%$ & $18.8 \%$ \\
\hline $1998-2001(3)$ & $4.4 \%$ & $2.9 \%$ & $21.0 \%$ & $80.6 \%$ & $61.4 \%$ & $19.1 \%$ \\
\hline$(2)-(1)$ & 2.8 & -0.5 & 1.2 & 2.1 & 1.3 & 0.8 \\
\hline $\begin{array}{c}\text { Contribution to the increase in } \\
\text { the CA deficit }\end{array}$ & $100.0 \%$ & $-17.8 \%$ & $43.2 \%$ & $74.6 \%$ & $45.5 \%$ & $29.1 \%$ \\
\hline$(3)-(2)$ & 1.1 & 1.5 & -0.6 & 0.1 & -0.3 & 0.4 \\
\hline $\begin{array}{c}\text { Contribution to the increase in } \\
\text { the CA deficit }\end{array}$ & $100.0 \%$ & $143.3 \%$ & $-53.2 \%$ & $9.9 \%$ & $-17.3 \%$ & $139.9 \%$ \\
\hline
\end{tabular}

Source: IBGE and authors' calculations. 
Table 11

Growth Rate and Volatility of Consumption and GDP in Brazil - 1974:2003

\begin{tabular}{|c|c|c|c|c|c|c|c|c|}
\hline \multirow{3}{*}{ Period } & \multicolumn{5}{|c|}{ Consumption } & \multicolumn{3}{|c|}{ GDP } \\
\hline & \multicolumn{3}{|c|}{ Growth Rate } & \multicolumn{2}{|c|}{ Share in GDP } & \multicolumn{3}{|c|}{ Growth Rate } \\
\hline & Average & $\begin{array}{l}\text { Standard } \\
\text { Deviation }\end{array}$ & $\begin{array}{l}\text { Coefficient of } \\
\text { Variation }\end{array}$ & Average & $\begin{array}{l}\text { Standard } \\
\text { Deviation }\end{array}$ & Average & $\begin{array}{l}\text { Standard } \\
\text { Deviation }\end{array}$ & $\begin{array}{c}\text { Coefficient of } \\
\text { Variation }\end{array}$ \\
\hline 1974-1982 & 4.95 & 5.30 & 1.07 & 78.5 & 1.4 & 5.03 & 4.49 & 0.89 \\
\hline 1983-1991 & 2.18 & 4.30 & 1.97 & 75.3 & 3.7 & 2.27 & 4.31 & 1.90 \\
\hline $1992-2003$ & 2.20 & 2.54 & 1.15 & 79.3 & 1.6 & 2.43 & 2.08 & 0.86 \\
\hline
\end{tabular}

Source: IBGE and authors' calculations.

Table 12

Determinants of Capital Flows (1995:1-2004:8)

\begin{tabular}{|c|c|c|c|c|c|c|}
\hline \multirow[b]{2}{*}{ Regressors } & \multicolumn{6}{|c|}{ Dependent Variable } \\
\hline & $\begin{array}{l}\text { Private } \\
\text { Capital } \\
\text { Account }\end{array}$ & $\begin{array}{c}\text { Debt } \\
\text { Securities }^{(1)}\end{array}$ & $\begin{array}{l}\text { Equities } \\
\text { (1) }\end{array}$ & $\begin{array}{l}\text { Loans } \\
\text { (1) }\end{array}$ & $\begin{array}{c}\text { Direct } \\
\text { Investment } \\
\text { (1) }\end{array}$ & $\begin{array}{l}\text { Official- } \\
\text { Agency } \\
\text { Loans }\end{array}$ \\
\hline Constant & $\begin{array}{r}1938.9^{*} \\
(1164.9)\end{array}$ & $\begin{array}{l}506.3^{*} \\
(262.3)\end{array}$ & $\begin{array}{r}488.2 \\
(701.8)\end{array}$ & $\begin{array}{r}122.2 \\
(450.8)\end{array}$ & $\begin{array}{r}1237.0^{\star *} \\
(537.9)\end{array}$ & $\begin{array}{r}-882.4 \\
(865.9)\end{array}$ \\
\hline U.S. Interest Rate & $\begin{array}{r}238.7 \\
(175.7)\end{array}$ & $\begin{array}{r}-14.0 \\
(38.8)\end{array}$ & $\begin{aligned} 147.4^{*} \\
(78.0)\end{aligned}$ & $\begin{array}{r}86.1 \\
(77.3)\end{array}$ & $\begin{array}{r}332.3^{\star * \star} \\
(64.8)\end{array}$ & $\begin{array}{r}-81.9 \\
(126.5)\end{array}$ \\
\hline Domestic Interest Rate ${ }^{(2)}$ & $\begin{array}{l}95.5^{\star *} \\
(39.1)\end{array}$ & $\begin{array}{r}20.7^{\star *} \\
(8.7)\end{array}$ & $\begin{array}{c}30.0^{*} \\
(16.3)\end{array}$ & $\begin{array}{l}33.7^{\star *} \\
(15.6)\end{array}$ & $\begin{array}{r}-70.2^{\star * \star} \\
(10.4)\end{array}$ & $\begin{array}{r}19.7 \\
(29.6)\end{array}$ \\
\hline EMBI+ Brazil & $\begin{array}{r}-426.6^{* * *} \\
(127.8)\end{array}$ & $\begin{array}{r}-0.7^{* * *} \\
(0.3)\end{array}$ & $\begin{array}{r}-1.7^{\star \star} \\
(0.8)\end{array}$ & $\begin{array}{r}-1.6^{\star * *} \\
(0.6)\end{array}$ & $\begin{array}{r}1.0^{\star} \\
(0.6)\end{array}$ & $\begin{array}{r}114.2^{\star \star} \\
(55.5)\end{array}$ \\
\hline R-squared & 0.3201 & 0.1857 & 0.1914 & 0.2302 & 0.1810 & 0.0518 \\
\hline Adjusted R-squared & 0.3015 & 0.1635 & 0.1693 & 0.2092 & 0.1587 & 0.0260 \\
\hline $\begin{array}{l}\text { Unit Root Test for the } \\
\text { Dependent Variable - p-value }\end{array}$ & 0.0071 & 0.0000 & 0.0984 & 0.0146 & 0.2343 & 0.0302 \\
\hline
\end{tabular}

Notes: Standard errors-shown in parentheses-were corrected by Newey-West heteroskedasticity and autocorrelation consistent covariance matrix estimator. Estimation using two-stage least squares. Instrument variables: constant, U.S. interest rate, and the variables domestic rate and Embi lagged one and two periods. ${ }^{*},{ }^{* *}$ and ${ }^{* * *}$ indicate the coefficient is significant at the $10 \%, 5 \%$, and $1 \%$ levels, respectively.

(1) These variables refer to net foreign investment.

(2) Minus expected exchange rate depreciation.

(3) P-value found using the augmented Dickey-Fuller test. Number of lags selected according to modified AIC, which generated the same number of lags as modified SIC. 
Table 13

Variance Error Decomposition (\%) - SVAR (1995:01-2004:08)

\begin{tabular}{|c|c|c|c|c|c|c|c|c|}
\hline Variables & $\begin{array}{c}\text { Standard } \\
\text { Error }^{\star}\end{array}$ & Output & $\begin{array}{l}\text { Current } \\
\text { Account }\end{array}$ & $\begin{array}{l}\text { Private } \\
\text { Capital } \\
\text { Account }\end{array}$ & $\begin{array}{l}\text { Terms of } \\
\text { Trade }\end{array}$ & $\begin{array}{l}\text { EMBI } \\
\text { Brazil }\end{array}$ & $\begin{array}{c}\text { Real } \\
\text { Effective } \\
\text { Exchange } \\
\text { Rate }\end{array}$ & $\begin{array}{l}\text { Real } \\
\text { Interest } \\
\text { Rate }\end{array}$ \\
\hline \multicolumn{9}{|l|}{$\overline{\text { Output }}$} \\
\hline 3 steps & 1.6 & 54.0 & 0.3 & 1.1 & 1.8 & 1.5 & 26.0 & 15.3 \\
\hline 12 steps & 2.3 & 26.3 & 14.1 & 12.9 & 3.9 & 9.4 & 21.5 & 11.8 \\
\hline 24 steps & 2.7 & 19.5 & 19.0 & 20.1 & 5.6 & 9.7 & 16.4 & 9.9 \\
\hline \multicolumn{9}{|l|}{ Current Account } \\
\hline 3 steps & 0.9 & 0.5 & 82.0 & 0.1 & 0.3 & 2.0 & 3.3 & 11.8 \\
\hline 12 steps & 1.2 & 4.7 & 57.8 & 4.1 & 3.1 & 8.4 & 8.6 & 13.5 \\
\hline 24 steps & 1.2 & 4.3 & 54.1 & 6.9 & 3.3 & 9.0 & 8.6 & 13.7 \\
\hline \multicolumn{9}{|c|}{ Private Capital Account } \\
\hline 3 steps & 4.1 & 5.1 & 1.5 & 37.6 & 0.8 & 23.1 & 23.7 & 8.2 \\
\hline 12 steps & 5.1 & 7.4 & 6.4 & 31.9 & 3.7 & 19.2 & 22.3 & 9.2 \\
\hline 24 steps & 5.3 & 7.2 & 6.7 & 31.2 & 3.9 & 18.6 & 22.1 & 10.2 \\
\hline \multicolumn{9}{|l|}{ Terms of Trade } \\
\hline 3 steps & 1.6 & 0.5 & 0.4 & 4.0 & 80.6 & 4.6 & 8.6 & 1.3 \\
\hline 12 steps & 2.9 & 1.1 & 10.9 & 11.2 & 33.8 & 19.7 & 19.7 & 3.6 \\
\hline 24 steps & 3.7 & 0.9 & 23.5 & 19.7 & 22.6 & 17.4 & 12.7 & 3.1 \\
\hline \multicolumn{9}{|l|}{ EMBI Brazil } \\
\hline 3 steps & 1.8 & 0.9 & 1.3 & 22.5 & 2.4 & 44.3 & 27.2 & 1.5 \\
\hline 12 steps & 3.2 & 2.5 & 11.8 & 35.3 & 1.5 & 33.7 & 10.5 & 4.8 \\
\hline 24 steps & 3.4 & 2.7 & 15.6 & 34.1 & 1.6 & 30.8 & 9.9 & 5.4 \\
\hline \multicolumn{9}{|c|}{ Real Effective Exchange Rate } \\
\hline 3 steps & 5.5 & 8.1 & 0.1 & 12.2 & 11.2 & 3.0 & 61.2 & 4.2 \\
\hline 12 steps & 8.4 & 7.2 & 9.9 & 16.8 & 8.7 & 21.8 & 31.7 & 4.0 \\
\hline 24 steps & 8.9 & 6.8 & 14.3 & 16.5 & 9.0 & 19.8 & 29.1 & 4.4 \\
\hline \multicolumn{9}{|l|}{ Real Interest Rate } \\
\hline 3 steps & 3.4 & 1.1 & 0.6 & 11.5 & 0.1 & 5.1 & 18.5 & 63.2 \\
\hline 12 steps & 4.9 & 3.2 & 4.6 & 15.1 & 17.2 & 7.8 & 21.1 & 31.0 \\
\hline 24 steps & 5.6 & 3.2 & 7.2 & 13.2 & 15.5 & 12.2 & 22.3 & 26.3 \\
\hline
\end{tabular}

* Standard errors are underestimated because their estimation assumes that coefficients are known. 